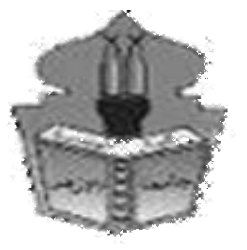

$$
\text { كلية الثريعة والقانون بأسيوط }
$$

$$
\text { عقوبة شاهد الزور }
$$

$$
\text { في الفقه الإسلاهي }
$$

$$
\text { د/ عرفة أبو شهمبة علي هممد }
$$

$$
-11 r .
$$


$-11 \leqslant-$ 


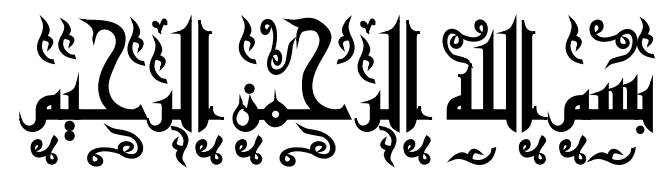

هو

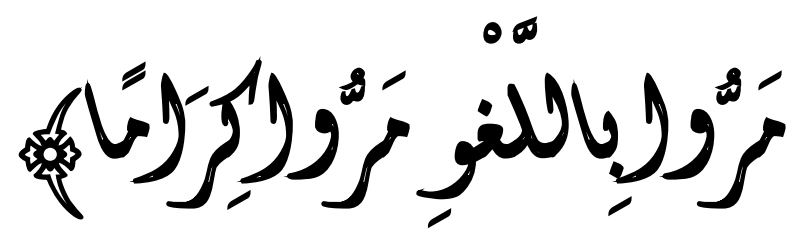

سورة الفرقان الآية (VY)

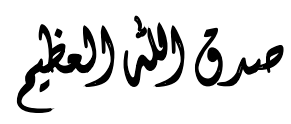




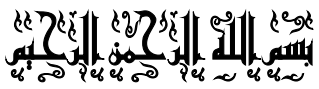

الحمد لله رب العالمين، أنعم علينا بنعمة الإيمان، وعاملنا

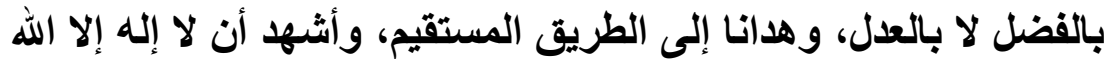

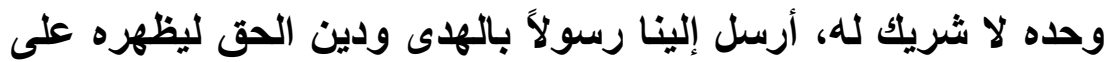

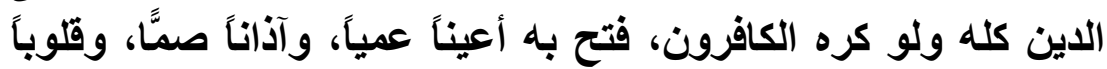

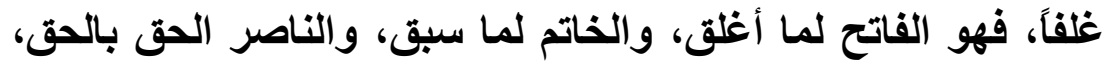

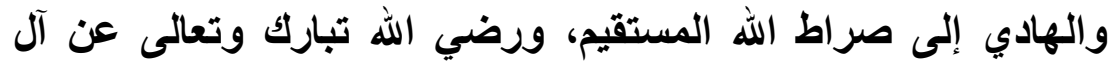
بيته الطبين الطاهرين، وأصحابه الغز الميامين، وتابع التابعين لهم بإحسان إلى يوم الاين. وبعد.....

فإن الثريعة الإسلامية اشتملت على كثير من الأحكام التي

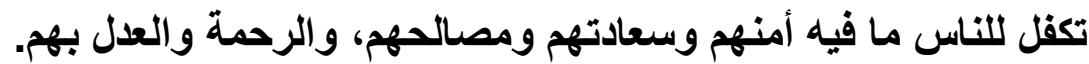

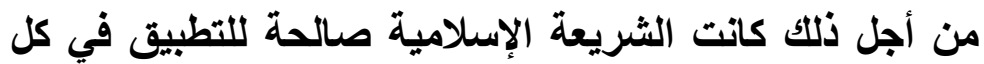

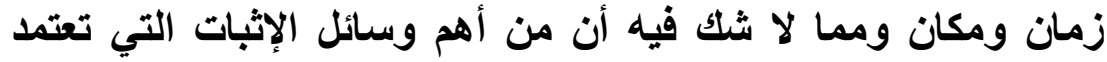

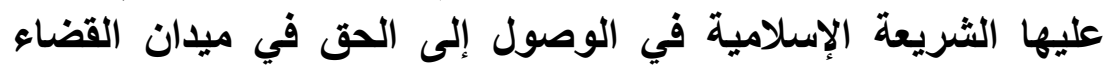

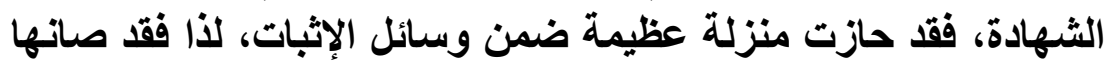
الإسلام بسياج قوي متين حينما اشترط لها شروطاً ووضع لهاد فها أسساً وقواعد تقوم عليها.

ثم بعد ذلك حذر الإسلام الذين يخالفون هذه الشروط والذين

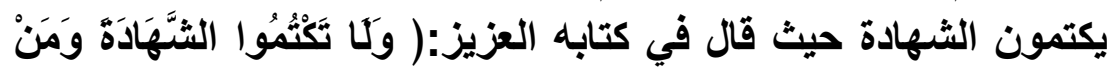

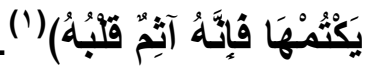
ولم يقتصر الأمر على ذلك بل جاء الإسلام مرسياً لقواعد العدل

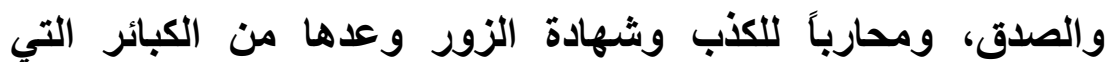

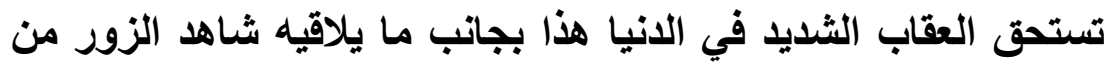

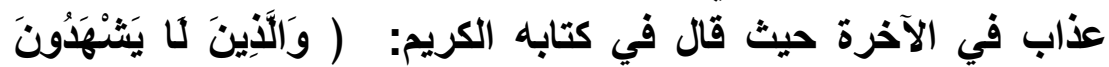




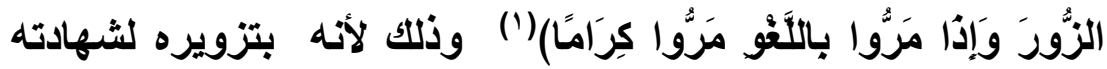

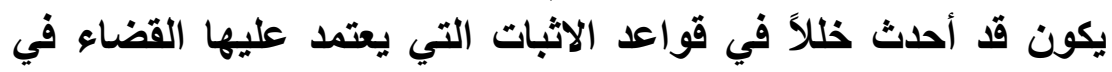

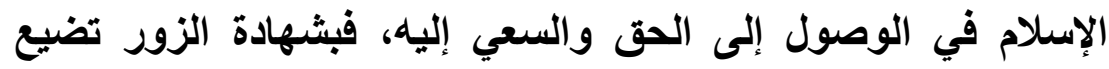
الحقوق، وتهار الكرامات، وينتشر الفساد في الأرض.

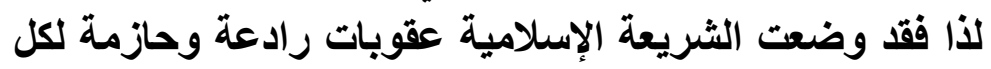

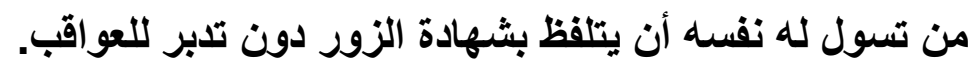

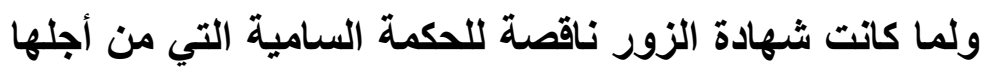

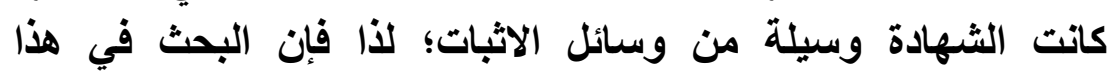
الموضوع يكون بالغ الأهمية.

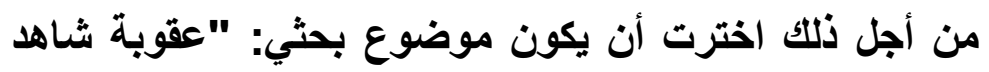

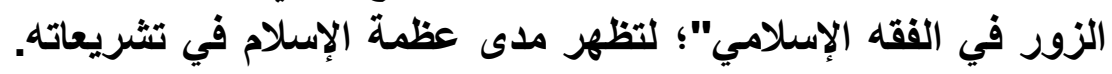

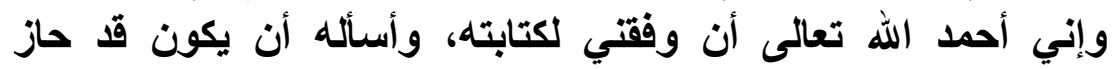

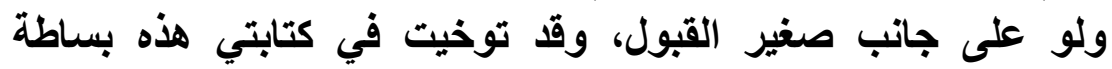

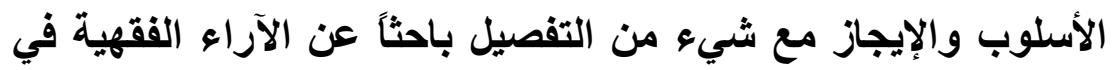

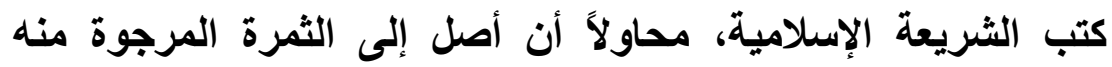

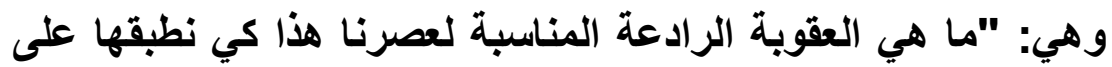

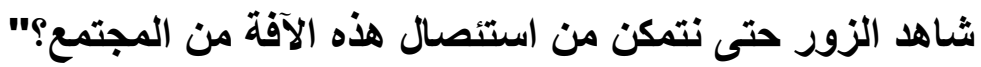

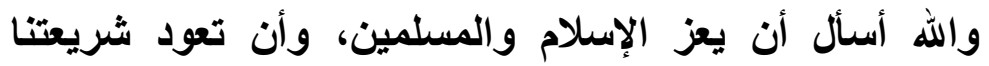

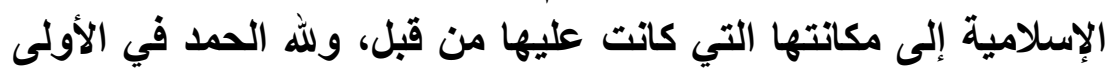
والآخرة، وله الحكم وإليه يرجعون، وهو نعم المولى ونعم النصير. 


\section{خطة البحث}

اقتضت طبيعة البحث أن يشتمل على تمهيد، وثلاثة مباحث،

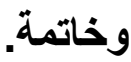

أما التمهيد: فيشتمل على تعريف الثهادة لغة وشرعًا، وأدلة

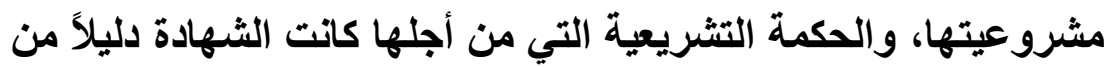

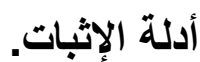

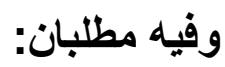

المطلب الأول: تعريف بالشهادة، وأدلة مشروعيتها. المطلب الثاني: الحكمة التثريعية التي من أجلها كانت الثهادئة

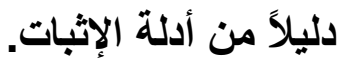

$$
\text { وأما المباحث فهي: }
$$

المبحث الأول: تعريف شهادة الزور، والنظرة التاريخية لها، ومدى إلئه

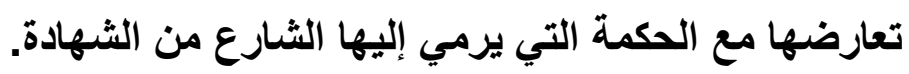

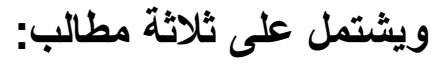

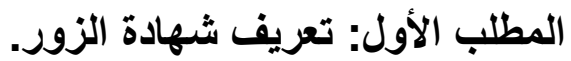

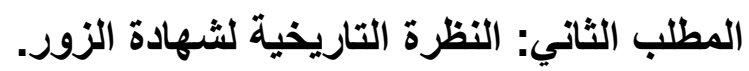

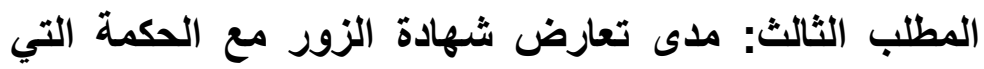
يرمي إليها الثارع من الثهادة.

المبحث الثاني: حكم شهادة الزور، وإثباتها، وعقوبتها.

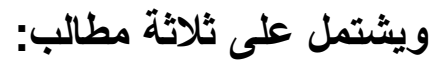
المطلب الأول: حكم شهادة الزور. المطلب الثاني: إثبات شهادة الزور. المطلب الثالث: عقوبة شاهد الزور. 
المبحث الثالث: الآثار المترتبة على الحكم بشهادة الزور في الفقه

الإسلامي.

ويشتمل على خمسة مطالب: الإسمي:

المطلب الأول: الأثر المترتب على على إقامة الحدود في شهادة

الزور.

المطلب الثاني: الأثر المترتب على القصاص بشهادة الزور.

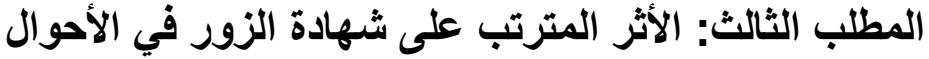

المدنية.

المطلب الرابع: الأثر المترتب على شهادة الزور في الأحوال

الثخصية.

المطلب الخامس: الأثر المترتب على الإكراه في شهادة الزور.

الخاتمة: وضمنتها أهم النتائج التي توصلت إليها من خلال هذا البحث. 


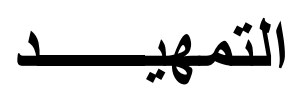

تعريف الثهادة لغة وشرعًا، وأدلة مشروعيتها، و الحكمة التهادة

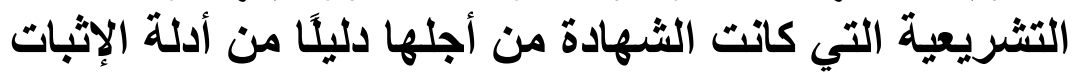

ويشتمل على مطالبين:

المطلب الثاني: تعريف الشهادة، وأدلة مشروعيتها.

المطلب الثالث: الحكمة التشريعية التي من أجلها كاتت

الثهادة دليَّا من أدلة الإثبات. 


\section{J11 \\ تعربف الشهادة وأدالة مشرو عيتها \\ الفرع الأول الفول \\ تعريف الشهادة لغة وشرعًا}

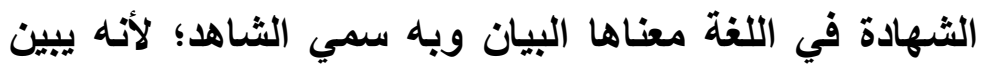

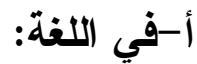

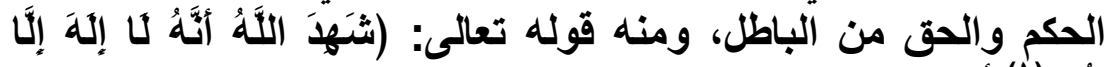
وتطلق على الإعلام والحضور، يقال: شهر زيد مجلس القوم:

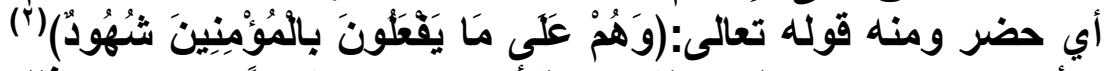

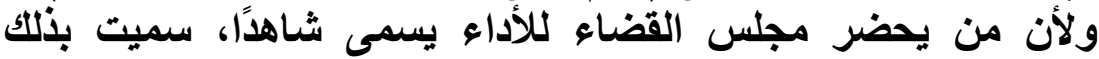

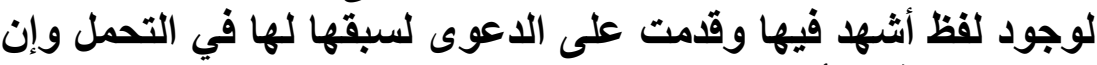

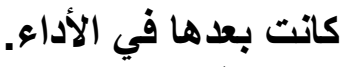
وتطلق الشَهادة على معاني أخرى منها:

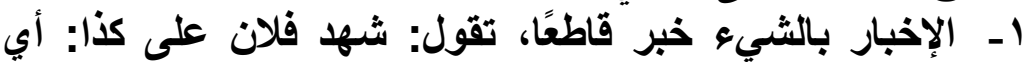

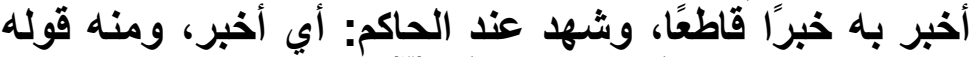

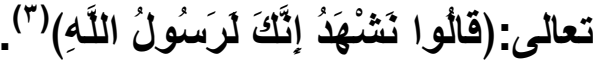

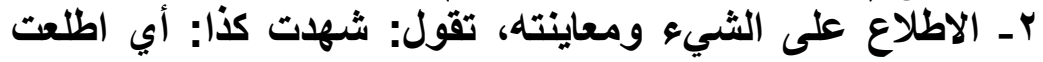
عليه و وعاينته.

r- إدرالك الثيء، وعاينه، تقول: شهدت الجمعة: أي أدركتها وأديتها. (؛)

$$
\begin{aligned}
& \text { (1) سورة آل عمران من الآية (1) (1). }
\end{aligned}
$$

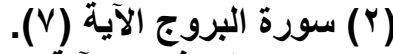

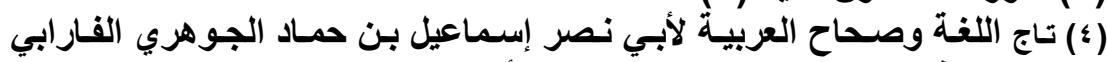

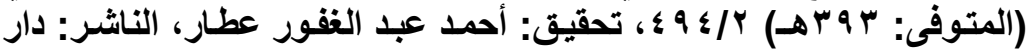

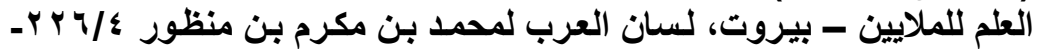

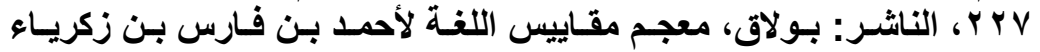

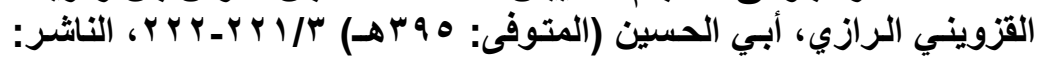

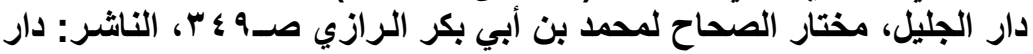
المعارف، تحقيق: عبد السلام محمد هارون. 


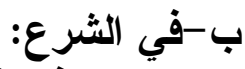

عرفها فقهاء الثريعة الإسلامية بتعريفات متعددة تبعًا لاختلاف

$$
\text { 1- المذاهب الحنفي: }
$$

عرفت الثهادة في المذهب الحنفي بتعريفات متعددة تختلف في

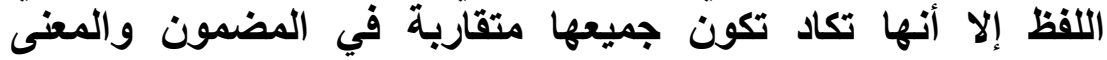
فالثهادة في المذهب الحنفي تغني: "إخبار صدق لإثبات حق بلفئ

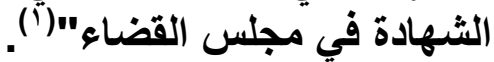

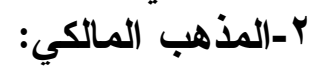
عرفت الشهادة في المذهب المالكي بتعريفات عديدة أذكر منها

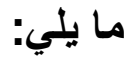
عرفها صاحب سراج السالكك بقوله:" إخبار عدل حاكمًا بما علم

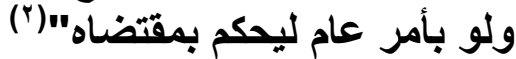
وعرفها الثيخ الدردير -رحمه الله بقوله:" إخبار حاكم عن

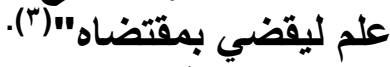
وعرفها الثيخ محمد بن عرفة الورغمي بأنها: قول هو بحيث

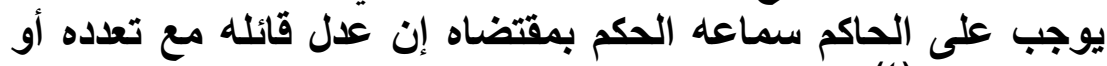

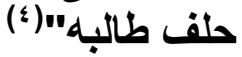
وعرفها بعض المالكية بأنها: إخبار بما حصل فيه الترافع

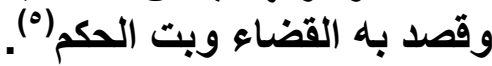

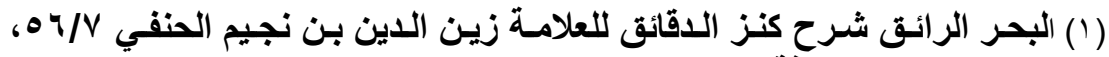
الناشر: دار المعرفة بيروت_البنان.

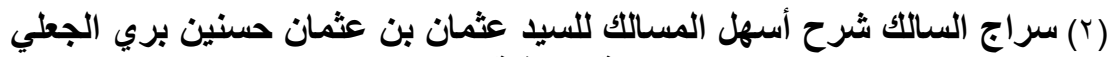

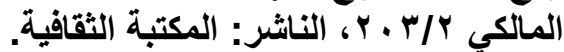

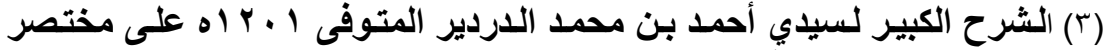

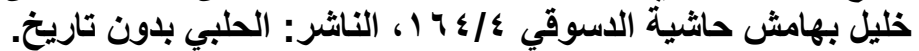

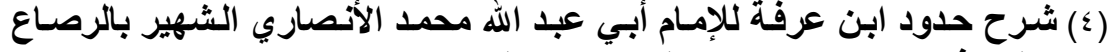

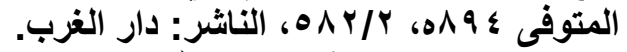

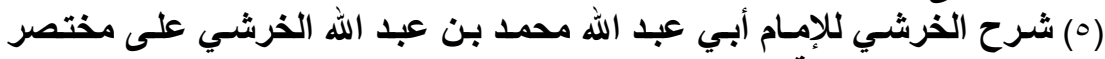

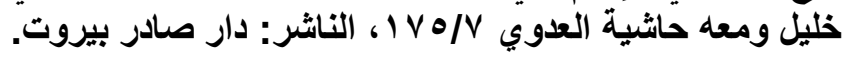




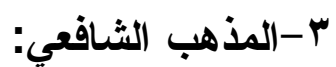

عرفت الثهادة في المذهب الثافعي بتعريفات متعدة نذكر

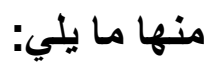

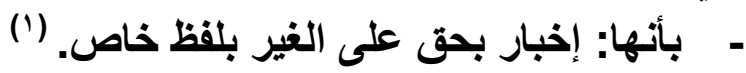

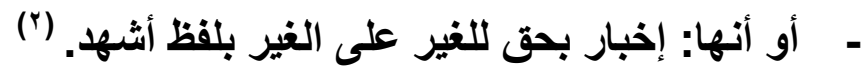

$$
\text { ع -المذهب الحنبلي: }
$$

عرف الحنابلة الثهادة بأنها: الإخبار بما علمه بلفظ خاص

$$
\text { هشهدت وأشهد ("). }
$$

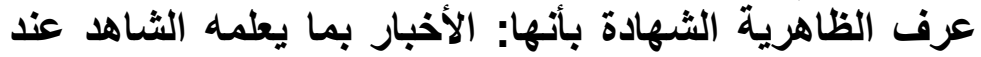

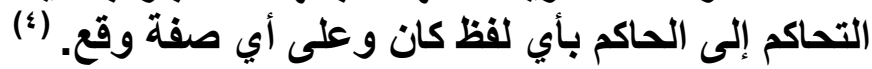

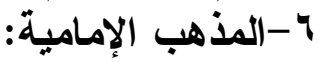

عرف الإمامية الشهادة بأنها: إخبار جازم عن حق لازم للغير

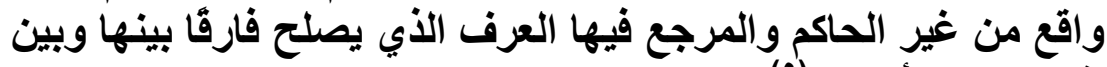

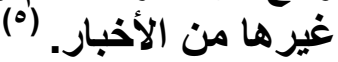

عزف الزيدية الثهادة بأنها إخبار بما علم بلفظ الثهادة. (")

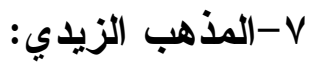

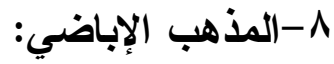

(") حاشية الجمل على شرح المنهاج للثيخ زكريا الأنصاري TVV/0 الناشر: دار إحياء التراث العربي.

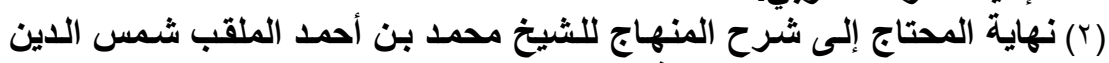

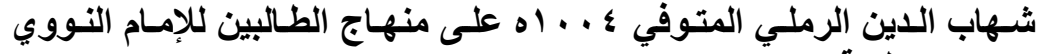

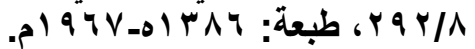

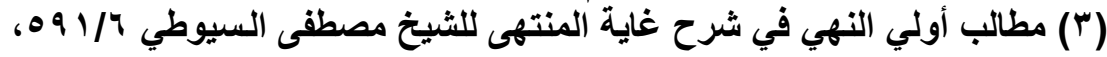

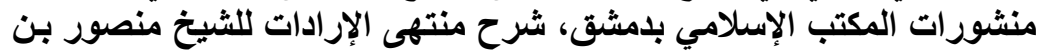

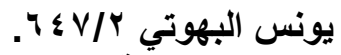

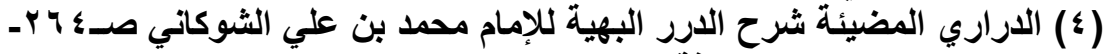

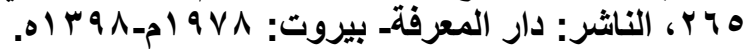

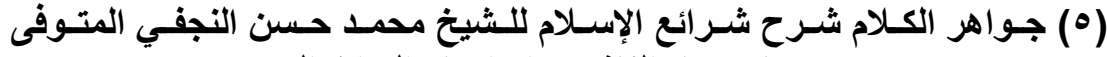

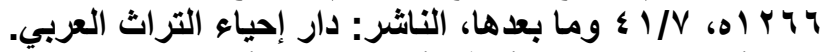

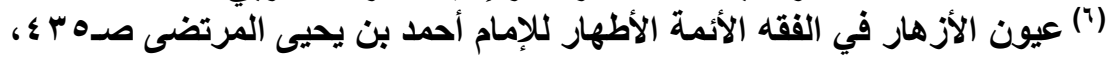

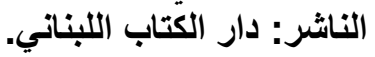


عرف الإباضية الثهادة بأنها: قول بحيث يوجب على الحاكم

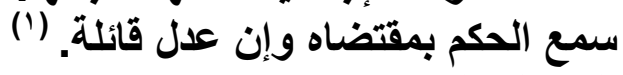

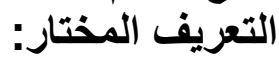

بعد عرض تعريف الثهادة عند الفقهاء فإني أميل إلى ترجيح واختيار تعريف الظاهرية وذلك للأسباب الآتية:

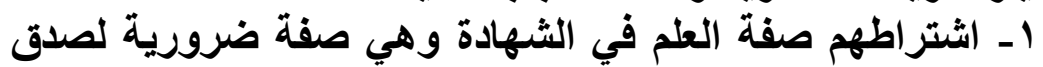

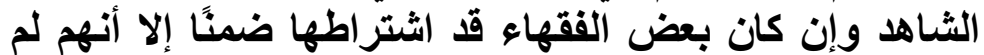

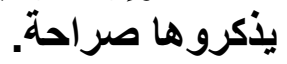

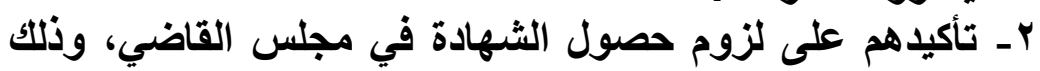

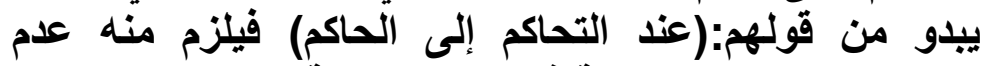

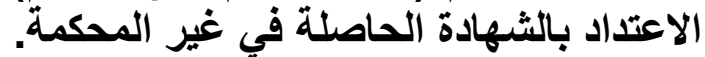

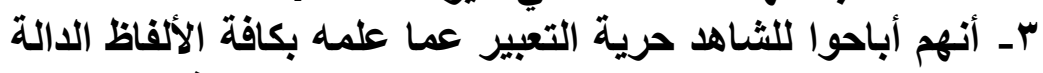

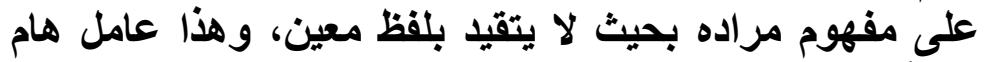

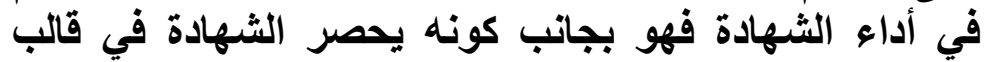

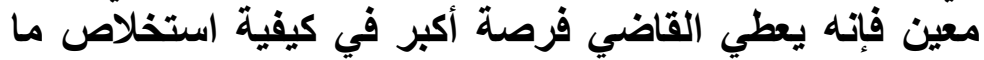

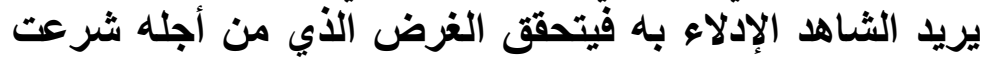

\section{الفرع الثاني \\ أدلة مشروعية الثشهادة}

الأصل في مشروعية الثهادة الكتاب والسنة والإجماع

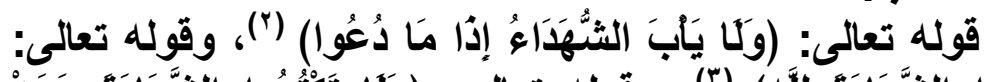

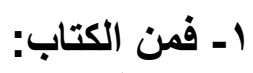

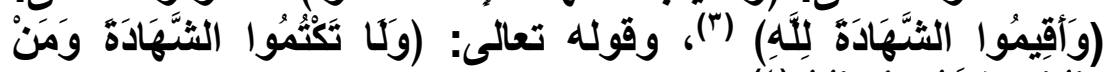

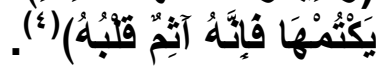

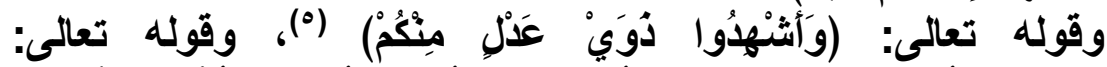

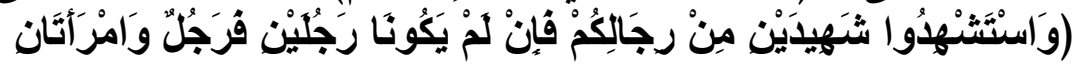

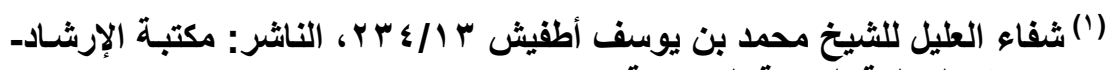
جأة الملكة العربية السعودية.

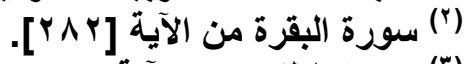

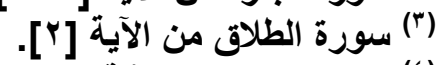

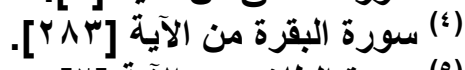

(0) سورة الطلاق من الآية [بr] 


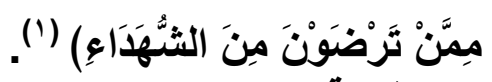

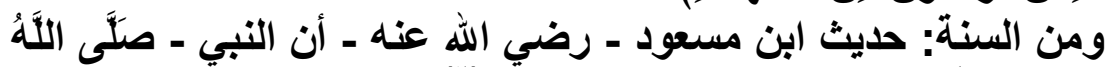

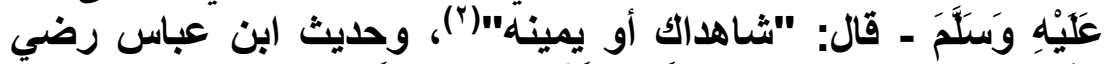

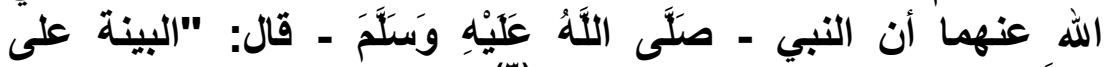

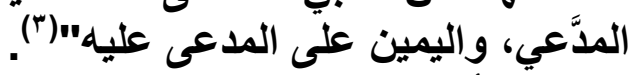
وأجمع العلماء على مشروعيتها؛ لإثبات الحقوق، ولأن الحاجة

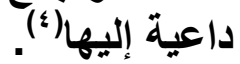

\section{المطلب الثاني}

\section{الهكمة النشريعية النيي من أبلها كانت الشهادة}

\section{دليلاً من أدالة الإثبات أنيات}

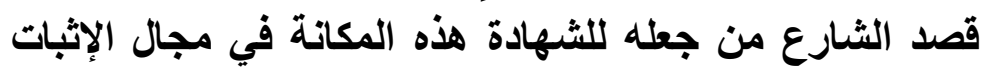

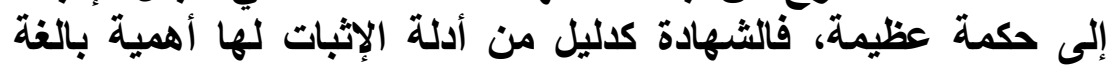

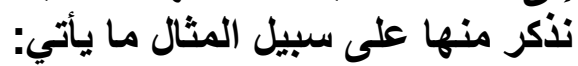

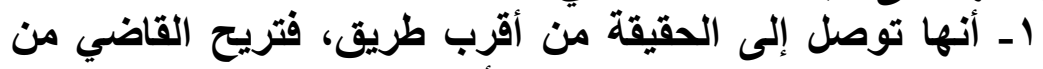
عناء البحث، وترد الحقوق إلى أصحابها.

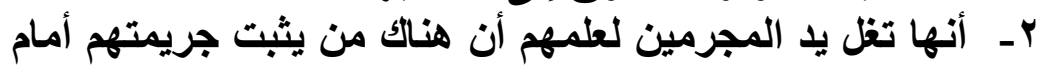

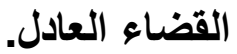

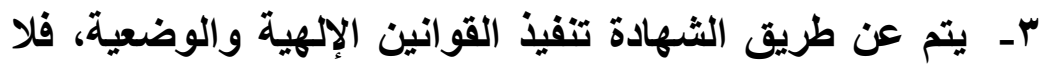

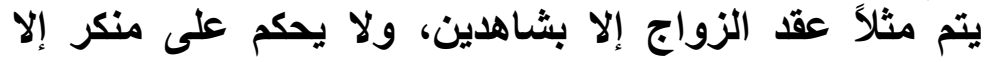

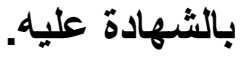

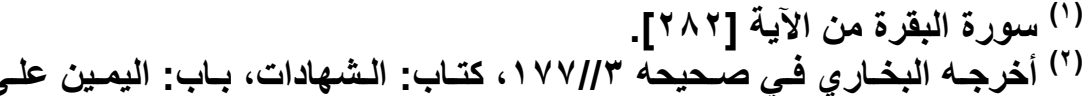

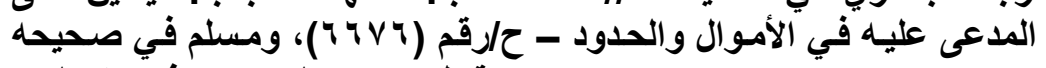

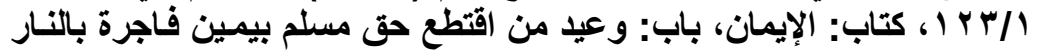

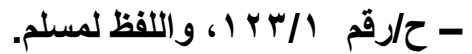

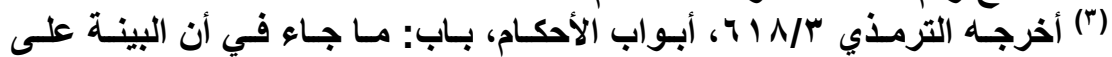

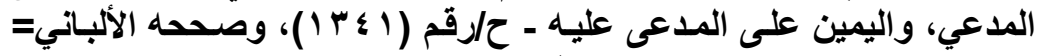

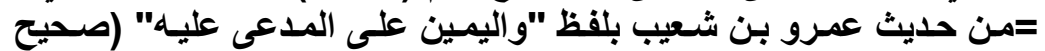

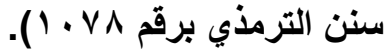

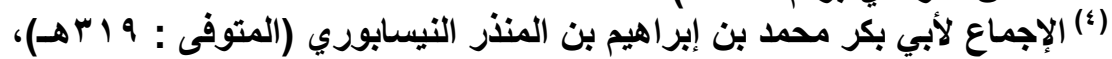

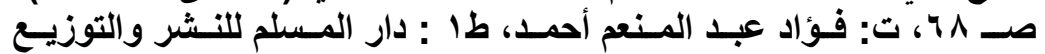
. ( . . . 
؛- تساعد على إثبات الدعاوى؛ لأن البينة (الثهادة) على المداعي واليمين على المدعى عليه.

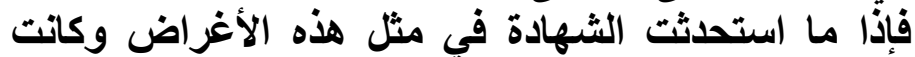

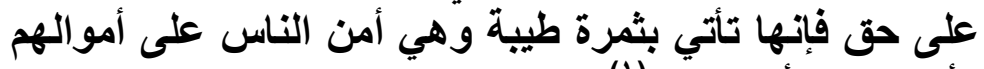

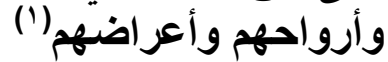

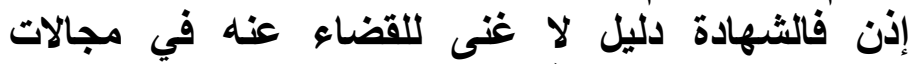

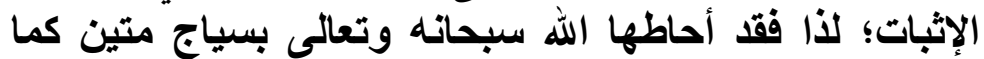

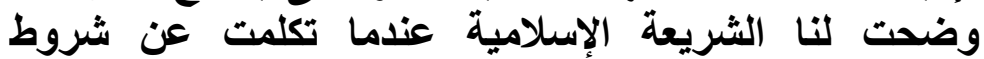

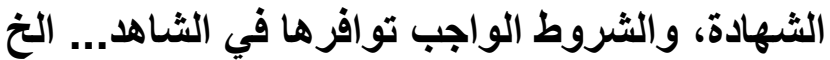
من أجل ذلك كله كانت الثهادة دليلاً من أدلة الإثبات.

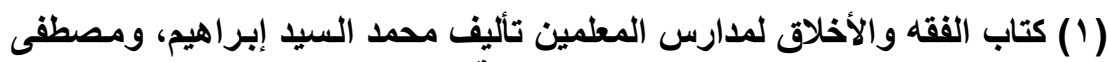

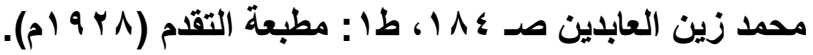




\section{المبحث الأول}

\section{تعريف شهادة الزور، والنظرة التاريخية لها، ومدى تعارضها مع الحكمة التي يرمي إليها \\ الثارع من الثهادة}

ويشتمل على ثلاثة مطالب:

المطلب الأول: تعريف شهادة الزور.

المطلب الثاني: النظرة التاريخية لشهادة الزور.

المطلب الثالث: مدى تعارض شهيادة الزور مع المكمة التي يرمي إليها الثـارع من الثهادة 


\section{المطلب الأول}

\section{تعريف شهادة الزور في اللغة وفي الاصطلام}

$$
\text { أ- الزور في اللغة: - مان }
$$

زور والزور: الصدر، وقيل: وسط الصدر، وقيل: أعلى الصدر،

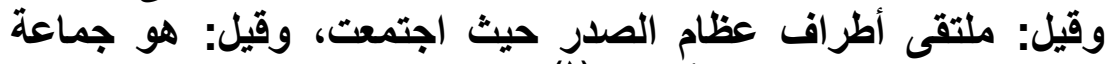
الصدر من الخلف والجمع أزئ أزوار.

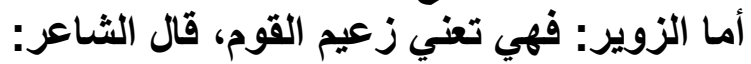

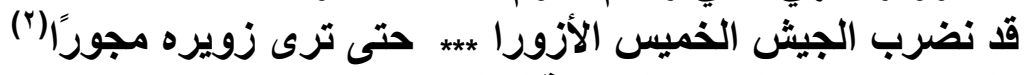

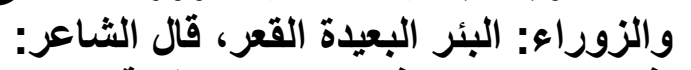

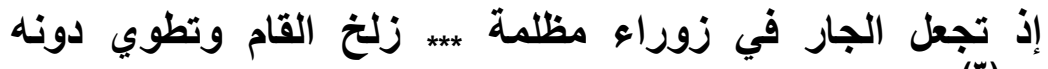

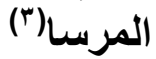
وقد يكون للكلمة هذه معنى آخر كأن تقول: زوَّرت الكلام في

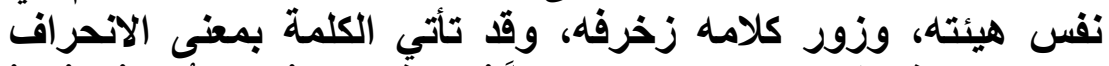

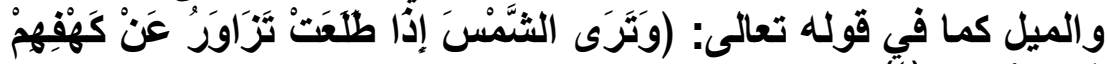

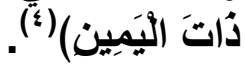
وأزور: أجرها في هذا الموضع أنها كاتت تطلع على كهفهم

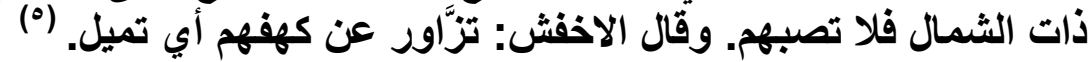

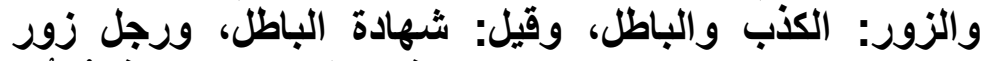

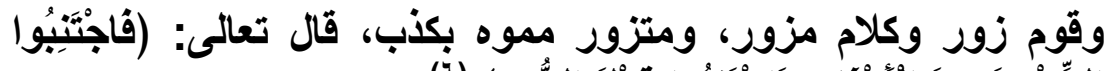

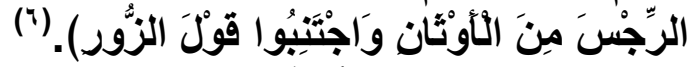

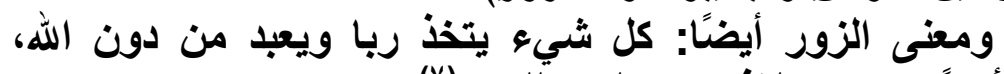

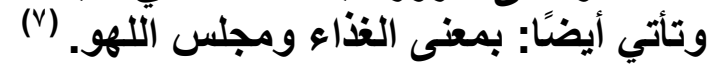
ب-تعريف شهادة الزور في الاصطلاح هي:

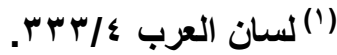

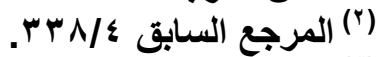

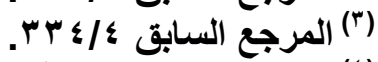

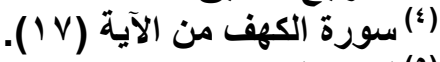

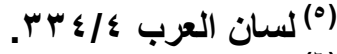

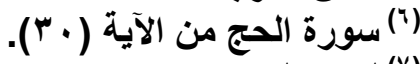

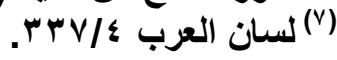


الثهادة بالكذب ليتوصل بها إلى الباطل من إتلاف نفس أو أخذ

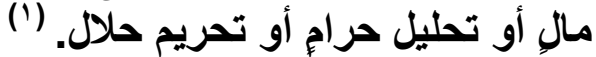

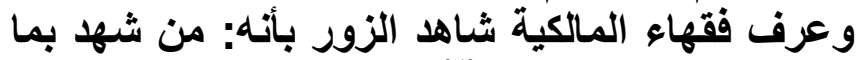

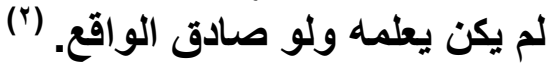

\section{المطلب النّانبي}

\section{النـظرة التناريخبة لثهادة الزور}

قبل التعرض لبيان مدى تعارض شهادة الزور مع الحكمة التي

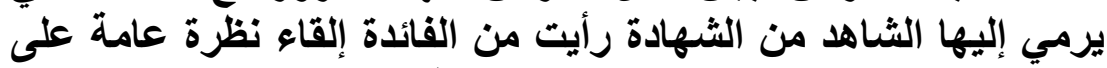
تصور شهادة الزور منذ المجمعات البذائية حتى هذا الحين من الفئ خلادل هذا المطلب.

أولَا: شهادة الزور في المجتمعات البلائية:ــ

اعتمد الإنسان في حياته البدائية الأولى على قنص الحيوانات

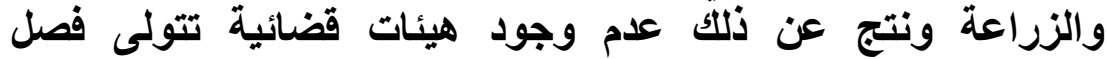

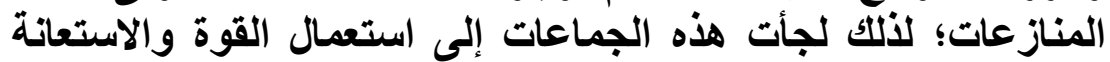

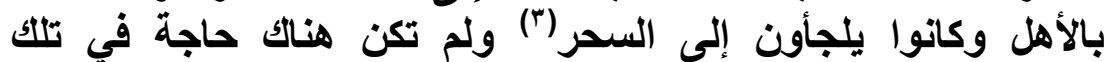

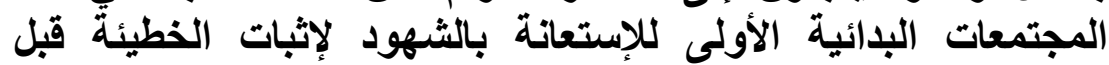

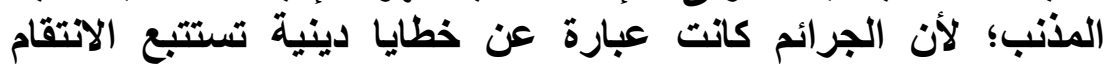

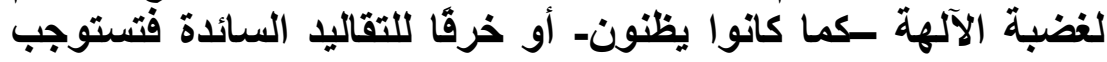

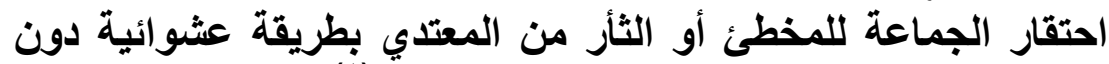

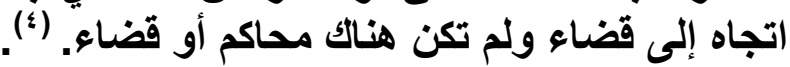

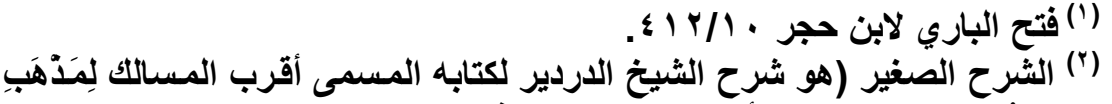

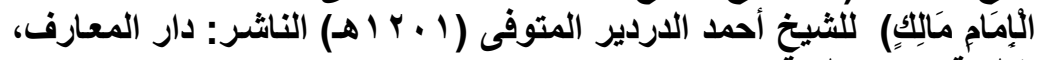

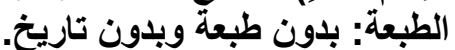

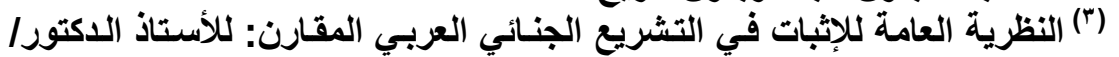

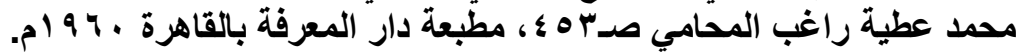

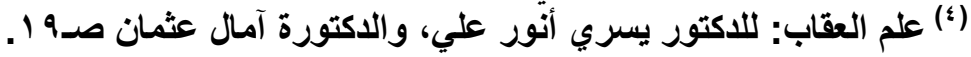




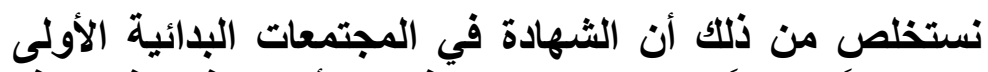

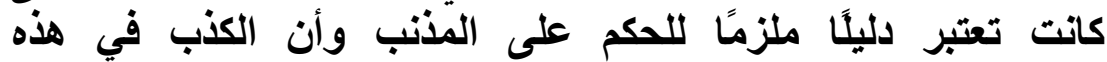

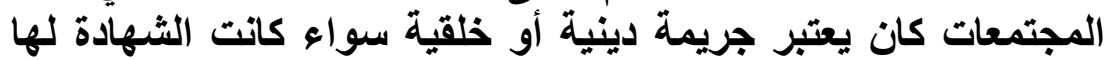
دور في هذه الحقبة الأولى من التاريخ أم لم يكن لهان لها دور.

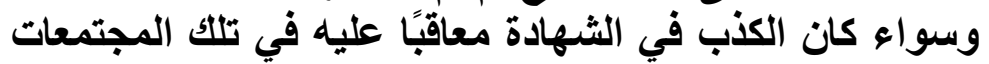

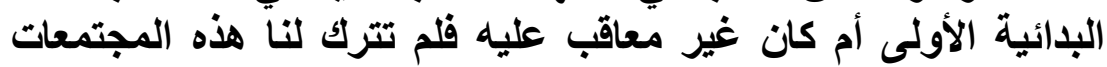

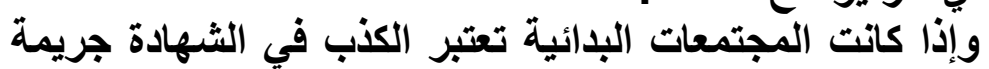

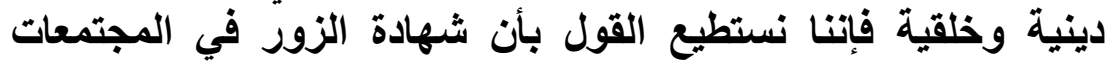

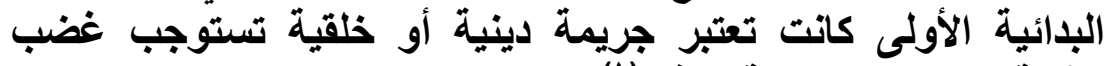

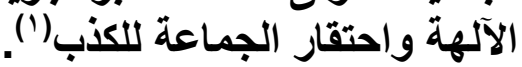

\section{ثانيًا: شهادة الزور في المجتمعات القبلية:}

بعدما اكتشفت المجتمعات البدائية الزراعة التي كاتت تعيش

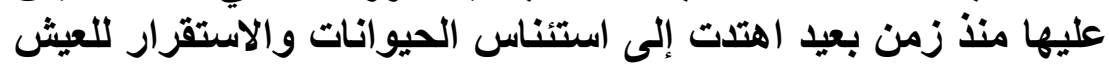

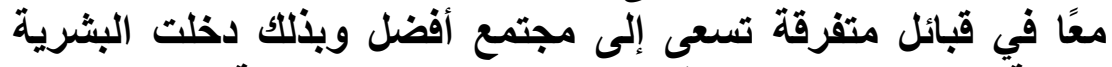

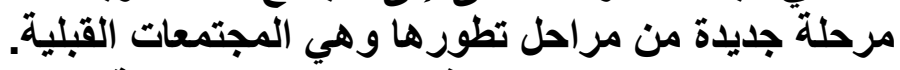

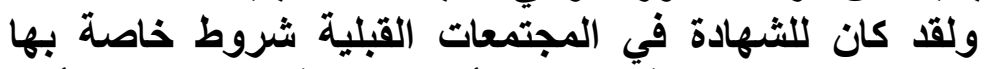

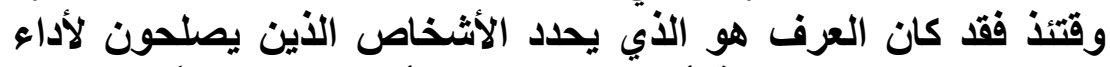

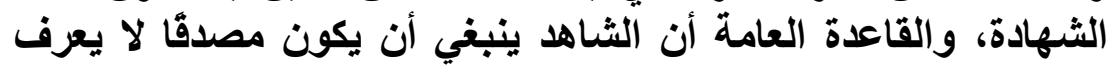

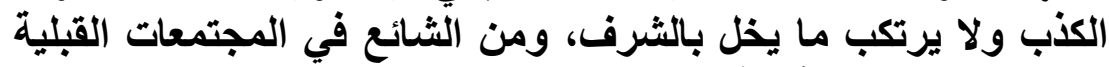

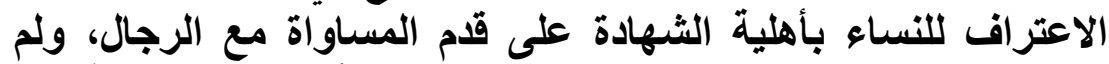

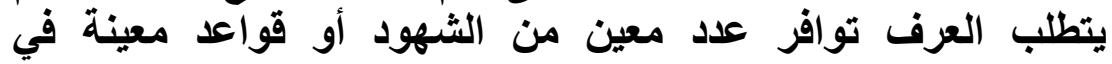

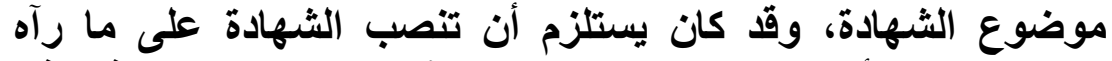

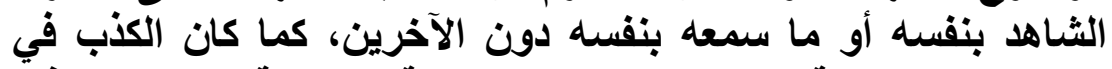

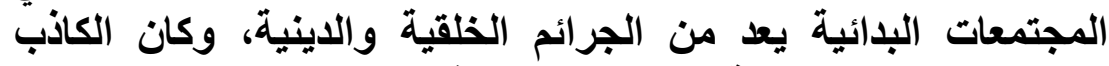

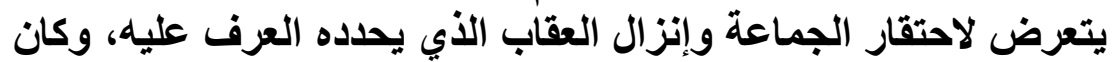

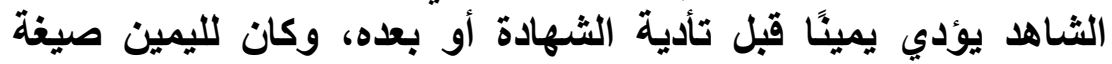
معينة جرى العرف بها وهي تختلف باختلاف القبائل.

(') 'الثهادة الزور من الناحيتين القانونية والعلمية للاكتور/ بهاء هابيل البرمساوي

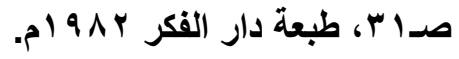


وكانت العقوبة المقررة للثاهد الكاذب تختلف باختلاف الضرر

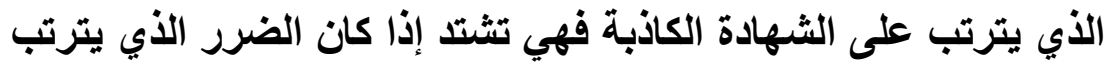

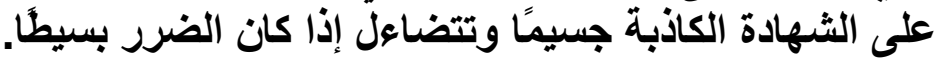

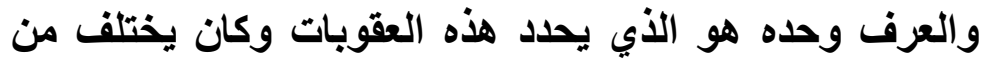

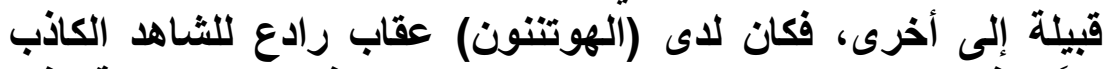

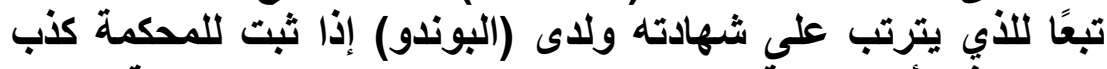

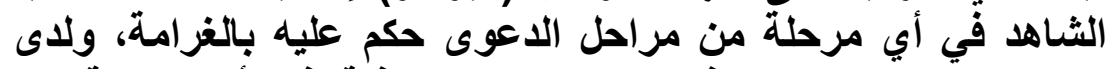

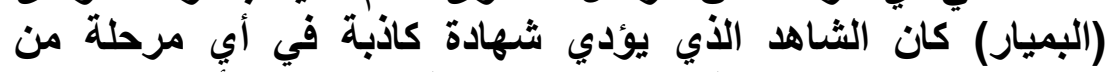

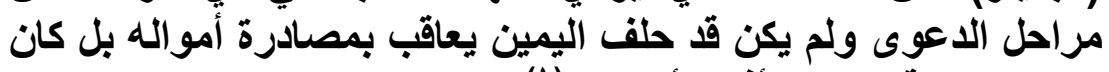

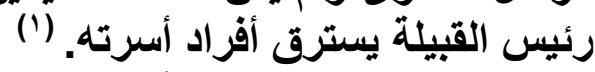
يستخلص من ذلك أن المجتمعات القبلية عرفت جريمة التهات شهادة

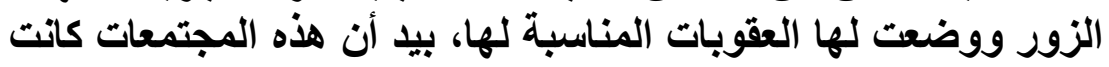

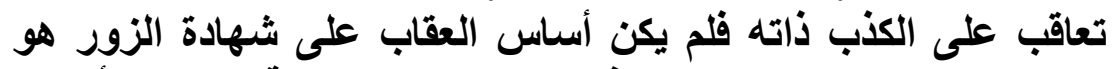

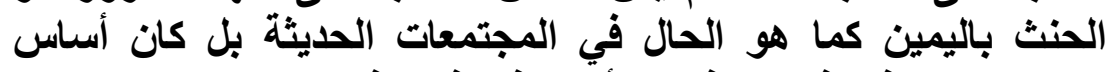

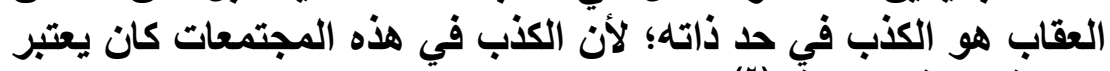

جريمة دينية وخلقية. ثأثًا: شهادة الزور في القوانية انين البابلية:

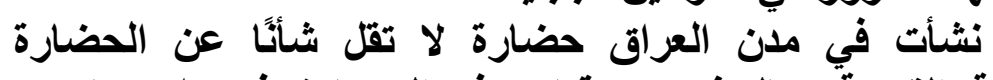

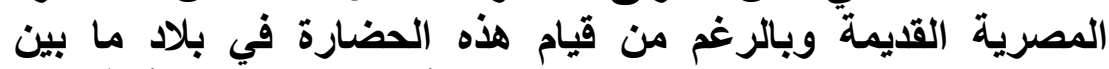

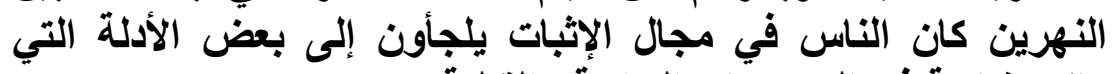

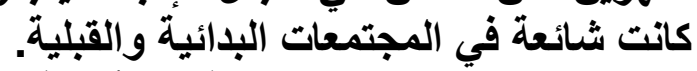

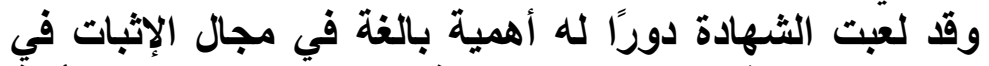

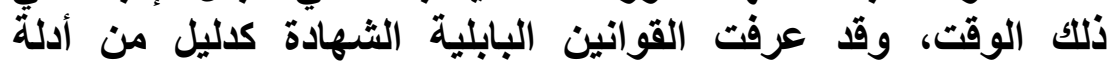

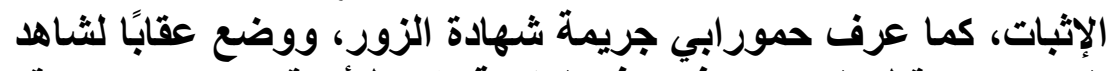

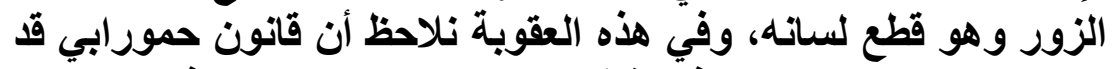

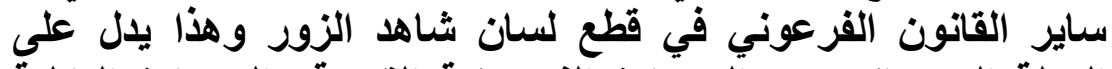

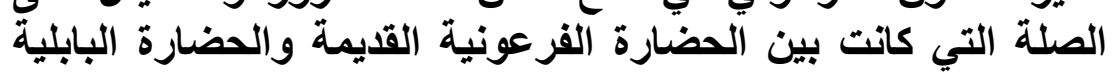

(1) تاريخ النظم الاجتماعية القانونية: للاكتور محمود سلام زناتي // إع، مطبعة

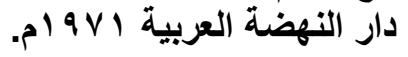
(") الثهادة الزور من الناحيتين القُنونية والعلمية: للاكتور بهاء هابيل البرشاوي-

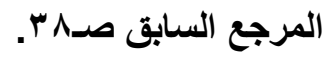




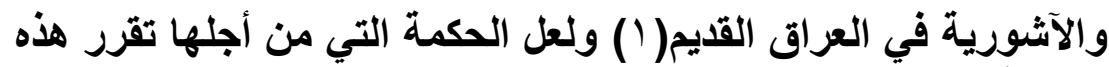

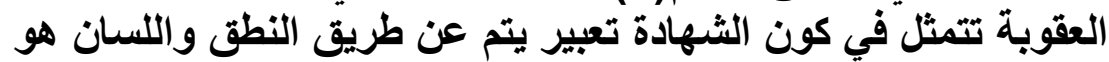

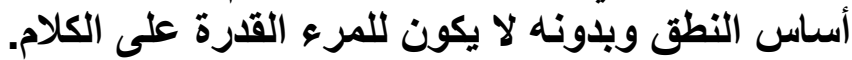

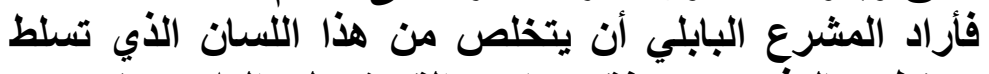
بغير حق ونطق بالكذب حتى يفقد صاحبه القدرة على الكلام، ولان يكون

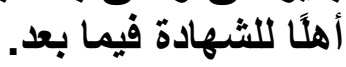

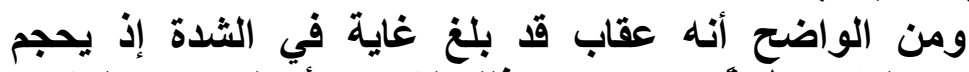

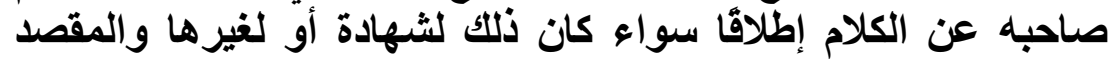

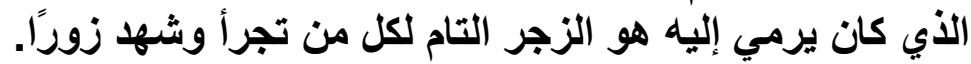

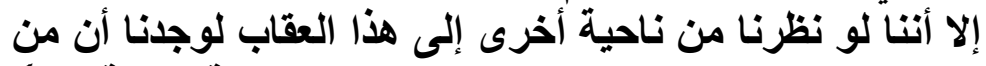

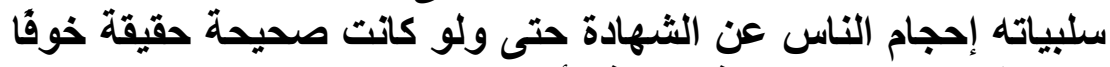
من توقيع العقاب عليهم فريما تذل ألسنتهم.

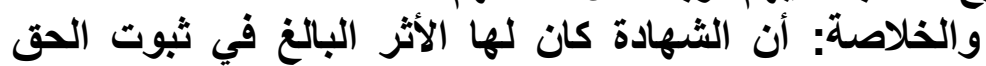

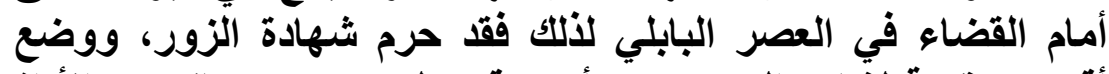

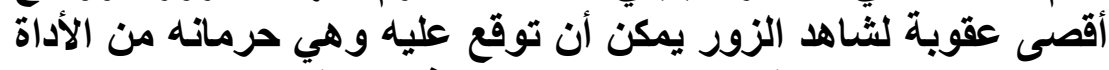

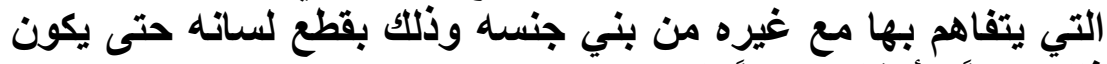

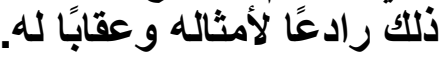

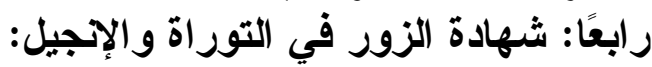
أ- شهادة الزور في التوراة:

كانت الثُهادة في التوراة من أهم أدلة الإثبات وكان يلتجأ

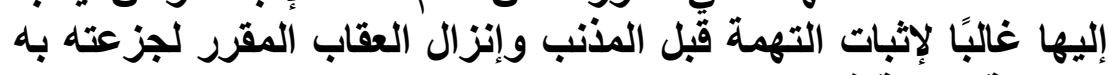

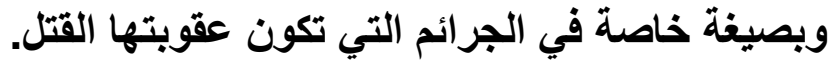

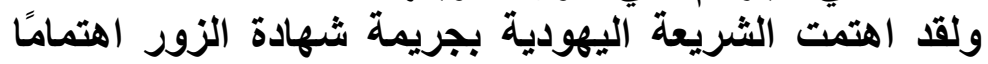

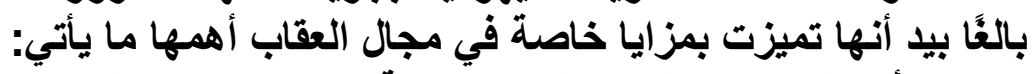

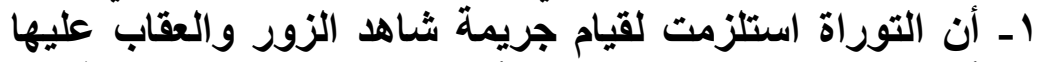

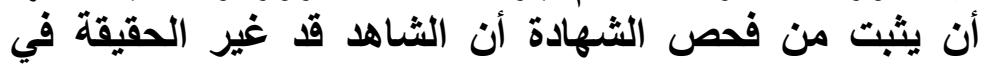
أقواله، وأن تكون قد انصرفت إلى هذان التها التغير بقصد الإضرار

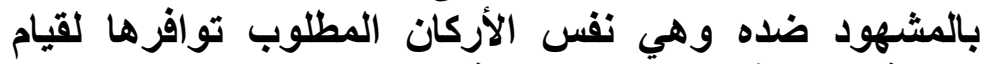
جريمة الزور في الثرائع الحديثة.

(') 'صول النظم القانونية في البلاد العربية: للاكتور محمود سلام زناتي صده ومـا بعد ها. 


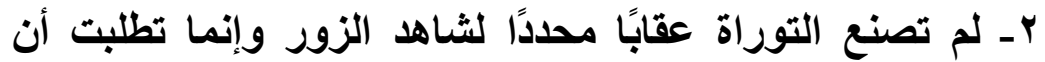

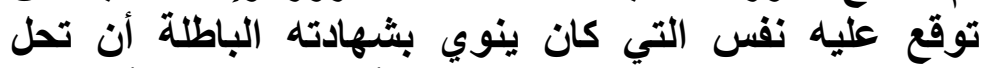

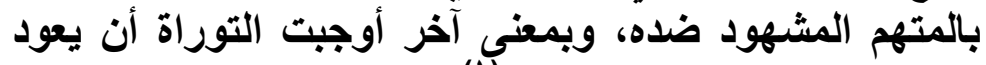

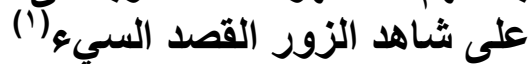

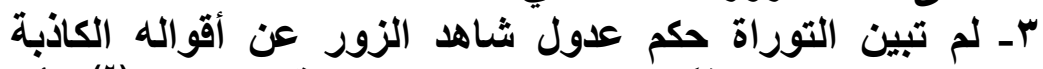

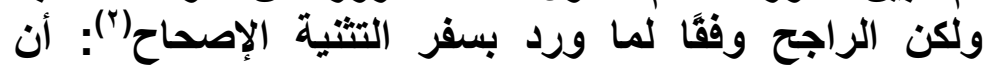

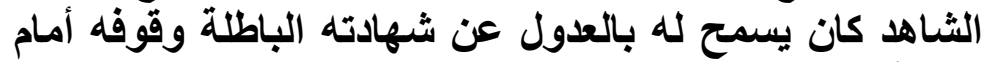

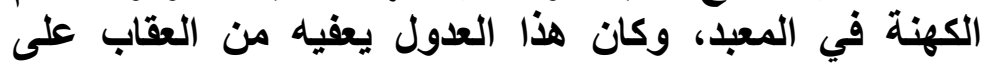

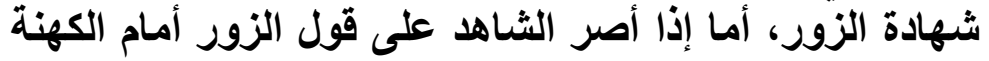
وداخل المعبد فلن يعفيه العدول بعد ذلإلك من العقاب.

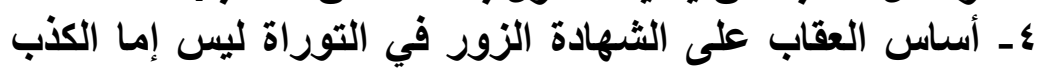

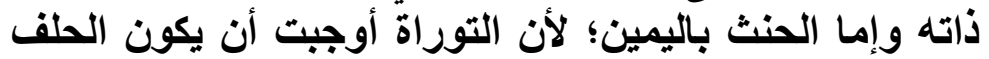

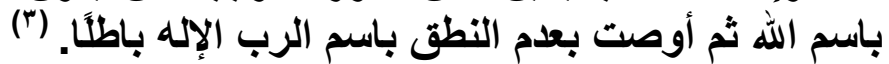
هـ أن التوراة استلزمت ضرورة عقاب الثاهد الزور لتحقيق باليق

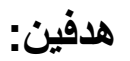
أـأن يعود على شاهد الزور قصده السيء وهذا مأدا أثنارت إليه

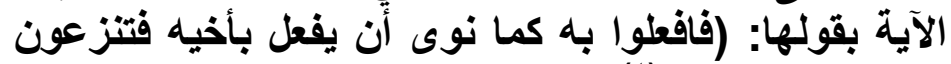

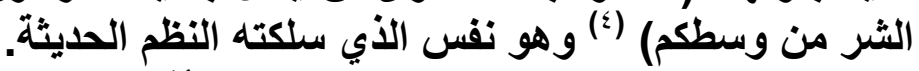

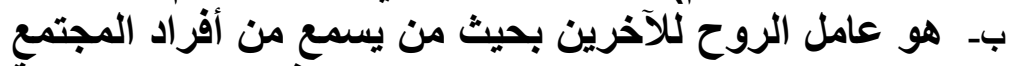

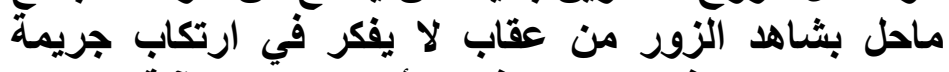

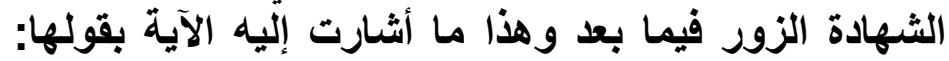
(ويسمع الباقون فيخافون ولا يعودون يفطون مثل ذللك الأمر

$$
\text { ب-شهادة الزور في الإجيل في وسك)(0). }
$$

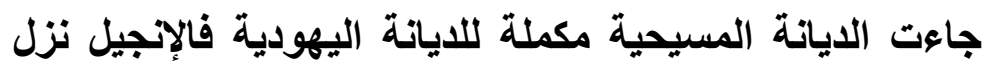
مكملًا للرسالة التي سبقته وهي التوراة ومعنى ذلك أن الأحكام التي نياني

( (1) الثهادة الزور من الناحيتين القانونية والعلميـة للـكتور/ بهاء هابيل البرمـاوي

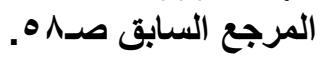

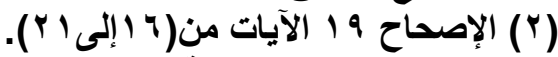

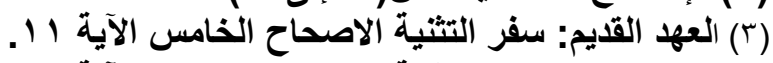

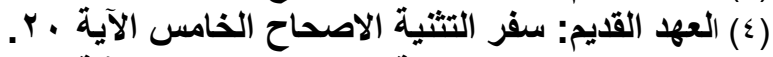

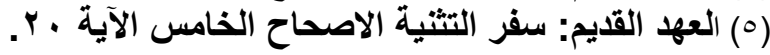


تضمنتها التوراة والخاصة بثهادة الزور وعقاب شاهد الزور هي ذاتها

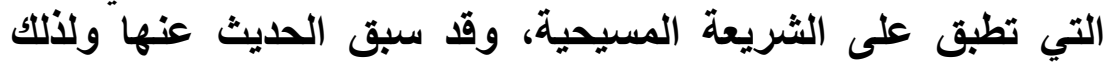
فنحن نكتفي بما تحدثنا عنه آنقا في الحديث عن شهادة الزئ الزور في

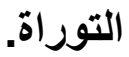
خامسًا: شهادة الزور في القانون الروماني:

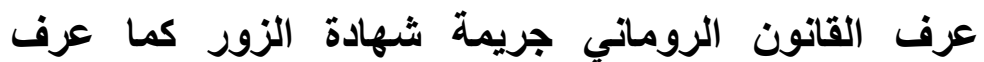

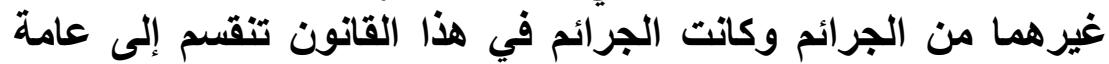

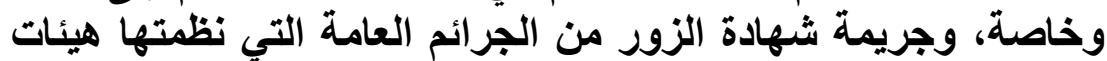

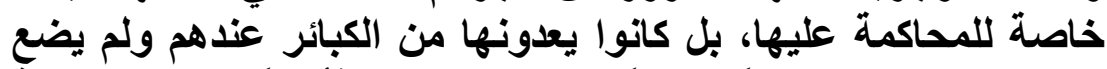

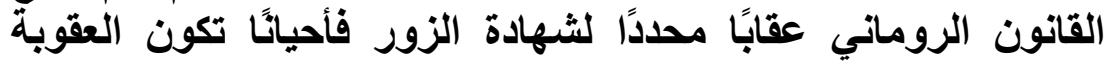

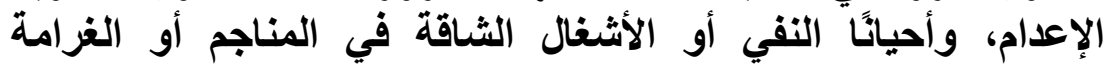

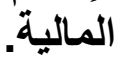

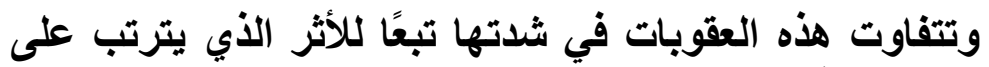

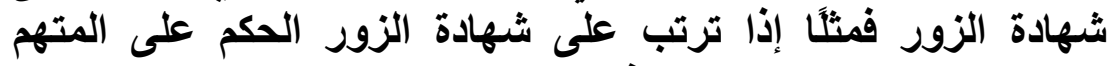

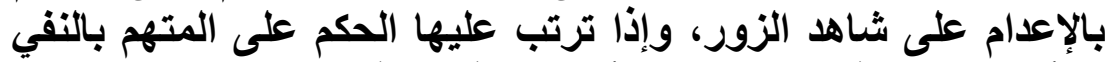
والأشغال الثاقة في المناجم، أو غرامة مالية كان يحكم على شاهل الزئ

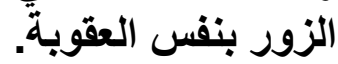

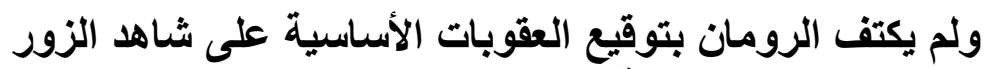

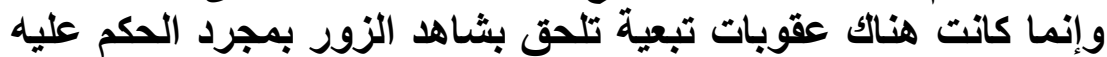

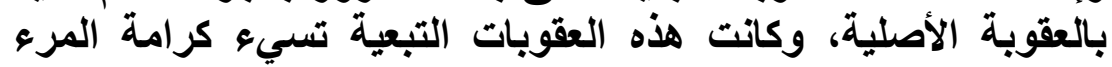
واعتباره وتحرمه من بعض الحقوق وتتمثل في عقويتان: أـ عدم الجدارة للشهادة.

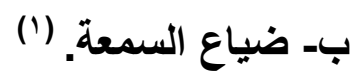

(') تاريخ القـانون الرومساني: دكتور عبدالمنعم البدراوي صـ. 9 ا، مبادئ القانون

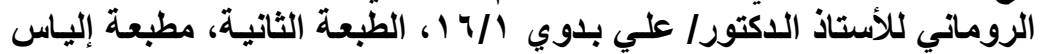

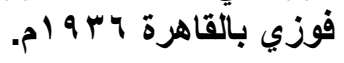




\section{المطلب الثالث}

\section{مدى تعارض شمادة الزور مع الهكمة التيه يرميي

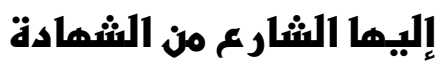

إذا كان الغرض الأساسي الذي من أجله كانت الثهادة دليلاً

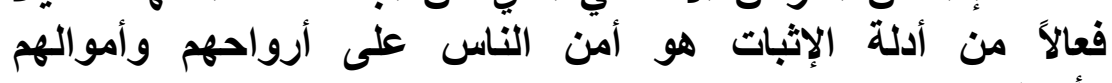
وذلكت يتمثل في حالة ما إذا استظلت الثهادة استغلالاً طيباً، وأعراضه. وتحملها أناس يحبون ألحق ويسعون في الوصول إليه؛ حتى لا تضيع

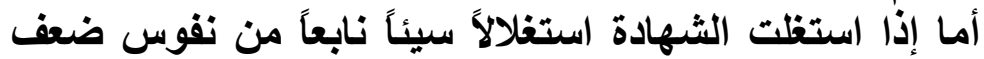

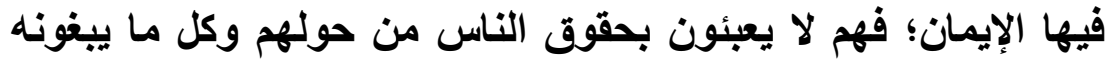

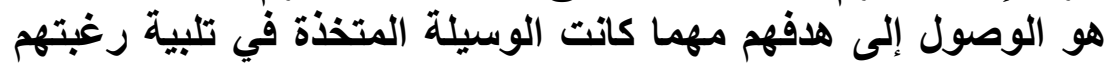

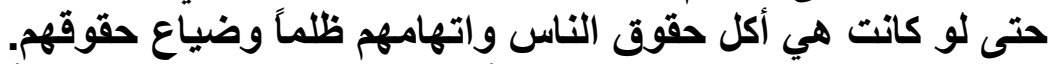

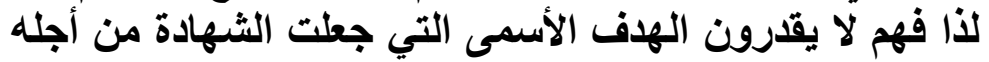

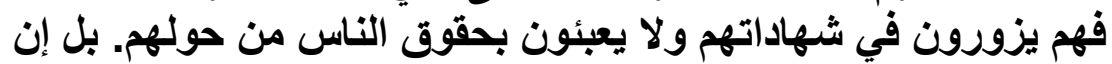

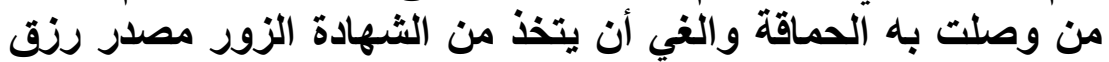

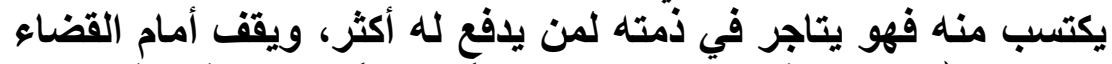

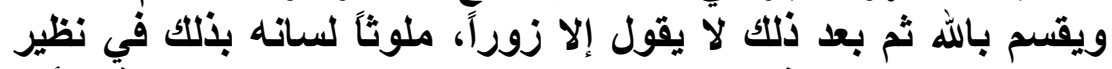

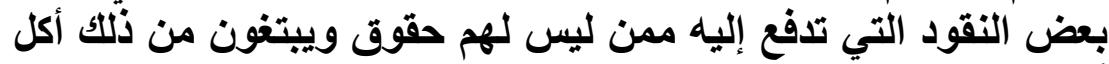

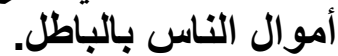

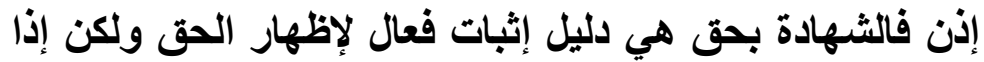

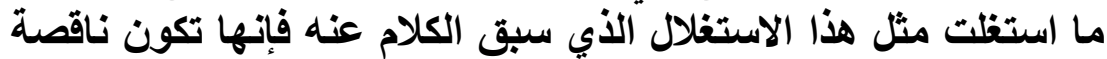

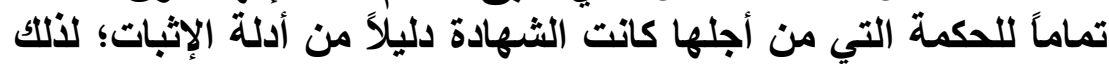

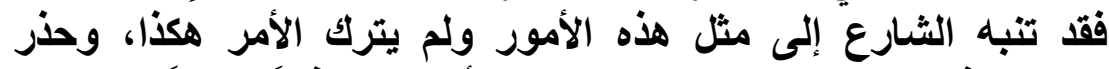

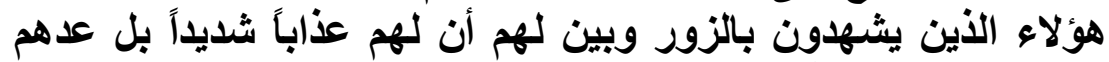

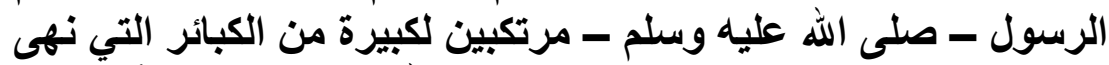
عنها الإسلام وكرر ذلتك حتى قال - صلى الله عليه وسلم -: ألاوقولئل الزور، ألا وقول الزور" (1).

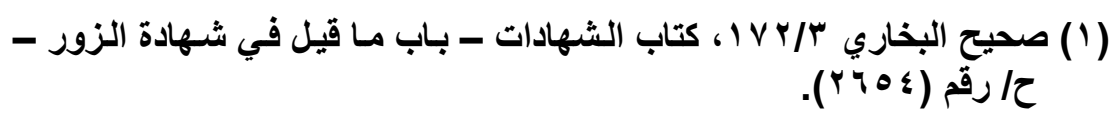


المبحث الثاني

حكم شهادة الزور و إثبات عقوبتها

ويشتمل على ثلاثة مطالب

المطلب الأول: حكم شهادة الزور.

المطلب الثاني: إثبات شهادة الزور.

المطلب الثالث: عقوبة شاهد الزور. 


\section{المطلب الأول}

\section{هكم شهادة الزور}

الأصل في الثاهد أن يقول الصدق؛ لأن الأصل في الفطرة

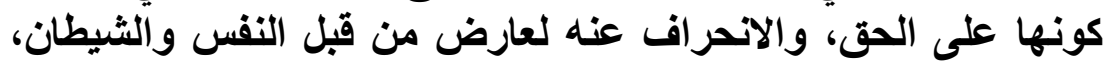

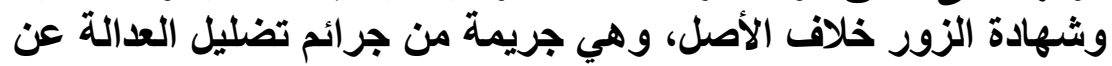

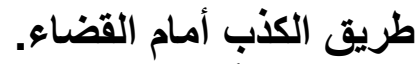
والأصل في تحريم شهادة الزور وعدها من الكبائر الكتاب

$$
\text { والولَّة: والإجتاب: }
$$

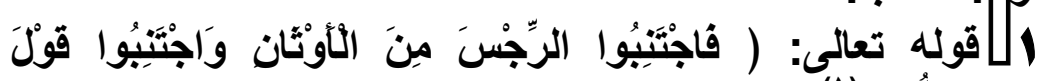

$$
\begin{aligned}
& \text { الزٔهُور) (') } \\
& \text { وجه الدلالة: }
\end{aligned}
$$

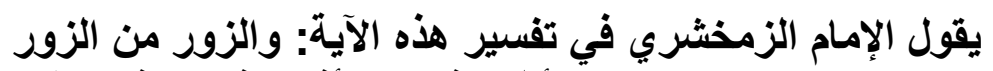

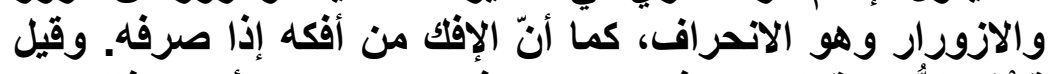

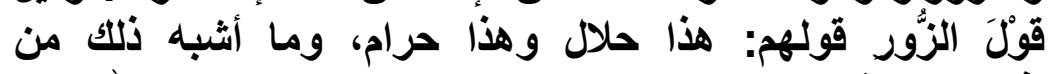

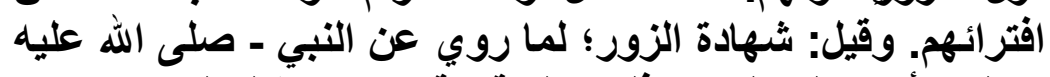

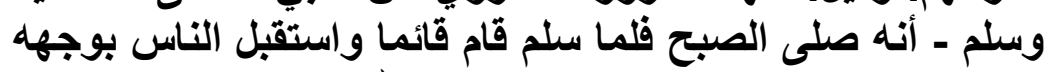

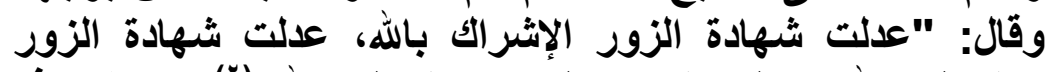

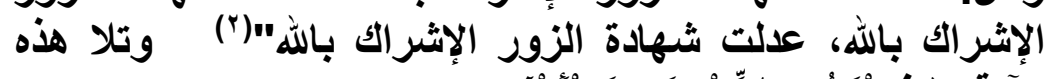

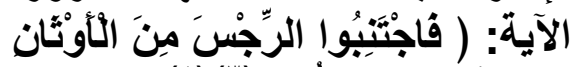

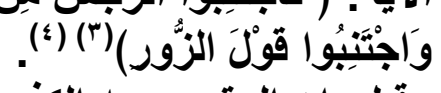

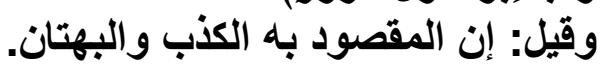

$$
\text { (1) (1) سورة الحج من الآية (·) (ب). }
$$

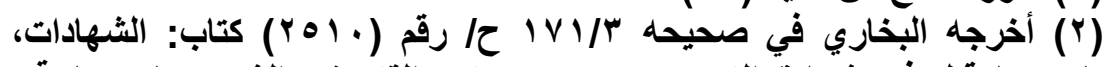

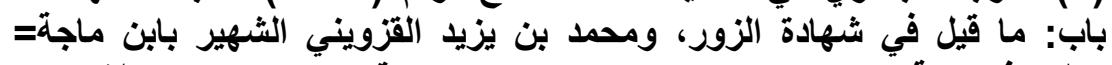

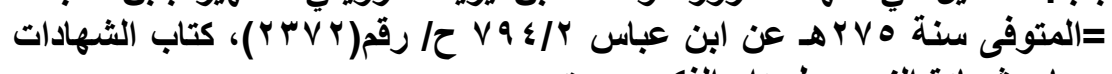

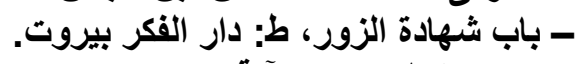

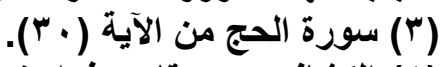

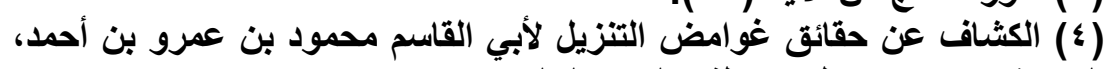
الزمخشري س/ 1 1 ، ط: مصطفى البابي الحلبي. - IrV 
وأيما كان الأمر فالقول الزور في هذا المجال يعني تغير الحقيقة

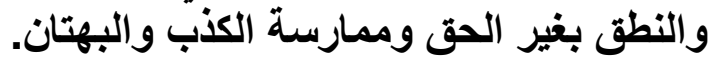
ويقول الإمام سيد قطب في تفسير هذه الآية في كتابه في ظلال

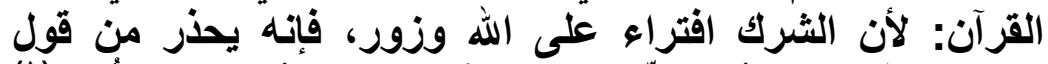

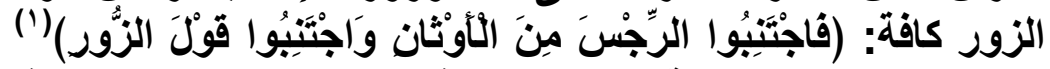

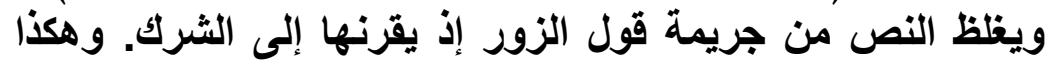

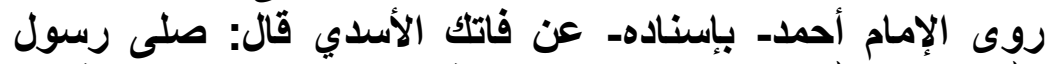

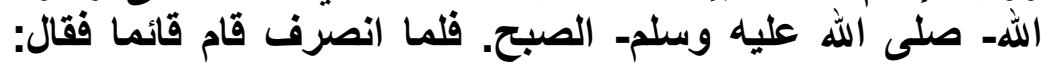

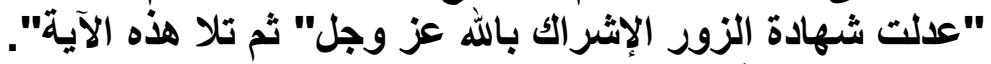

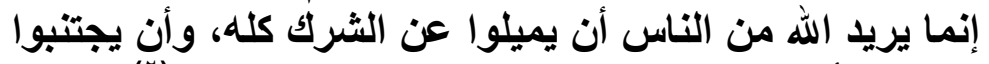

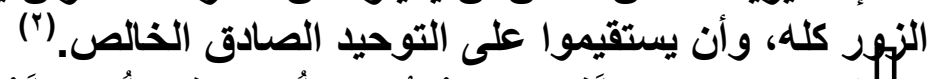

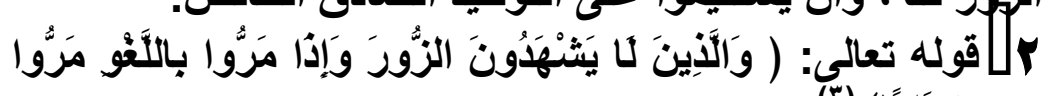

$$
\text { وجه الدرَامَا) ("الي. }
$$

قال ابن عباس: المقصود بذلك الذين لا يحضرون الكنب وولا

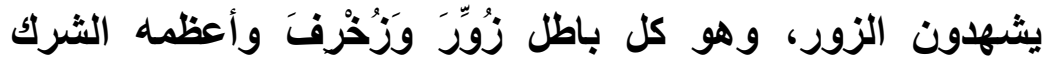

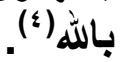
ويمكن أن يقال: إن الله تبارك وتعالى قد ذكر شهادة الزور إلى الى الكي جانب الكبائر الأخرى كالثرك باله، أو الزنا، أو أو القتل، وعقوق الزوق الو الدين. وهو دلالة على عظم جرم شهادة الزئل الزور. ويقول الإمام الزمخشري في تلفسير هذه هذه الآية:

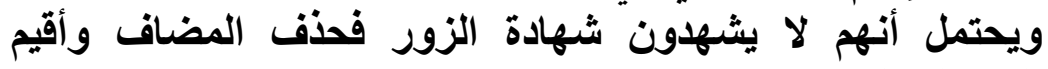
المضاف إليه مقامه. وعن قتادة: مجالس الباطل. وعن أبي حنيفة: اللهو والغناء. وعن

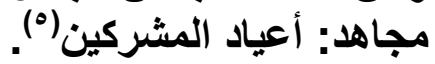

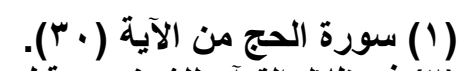

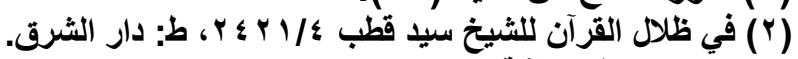

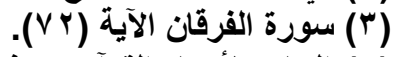

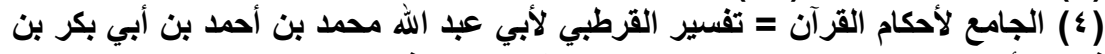

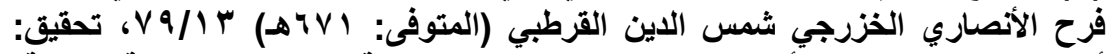
أحمد البردوني وإبراهيم أطفيش الناشر: دار الكب الدصرية ـ القاهرة، الطبعة: الثانية، 
ويقول الثيخ الألوسي في تفسير هذه الآية: والذين لا يشهدون الزّور: أي لا يقيمون الثهادة الكاذبة كما روي عن علي كرم الله وجهه، فهو من الثهادة والزور منصوب على لألى

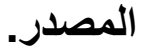

وأخرج جماعة عن مجاهل أن المراد بالزور الغتاء، وعن قتادة أنه

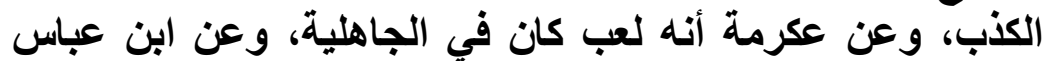

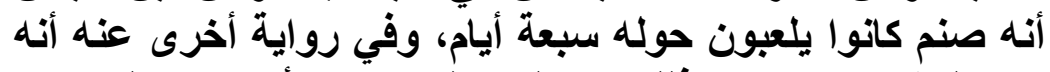

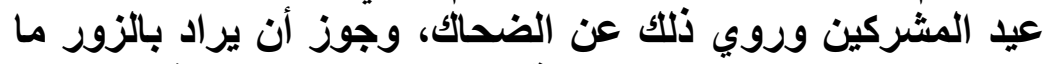

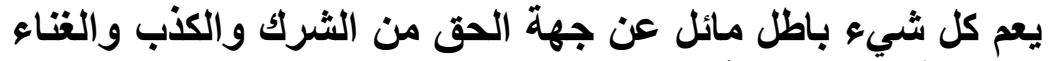

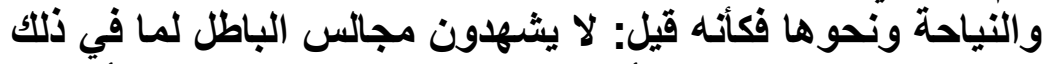
من الإثعار بالرضا به، وأيضا من حام حول الحمى يوشك أن أن يقع

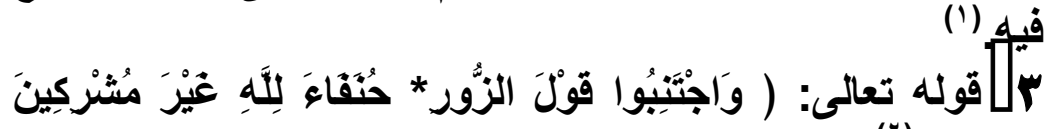

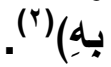

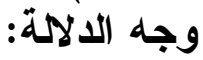

قرن الله سبحانه وتعالى في هذه الآية الكريمة شهادة الزور بالثرك به وهو من أكبر الكبائر، فهذا دليل على تحريمها وكونها

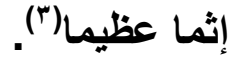

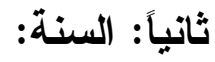

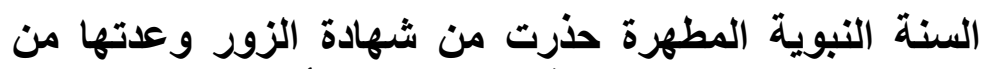

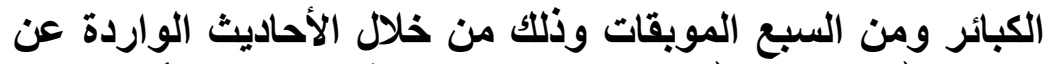

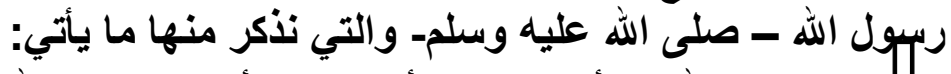
الك عن عبيل الله بن أبي بكر بن أنس، عن أنس -رضي النه الله عنهـ قال: سئل النبي -صلى الله عليه وسلم- عن الكبائر، قال:

(1) روح المعاني في تفسير القرآن العظيم والسبع المثاني للعلامة الألوسي

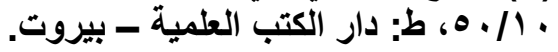

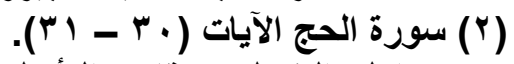

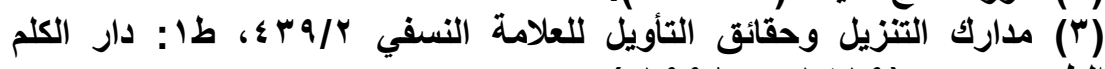

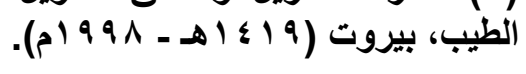


"الإشراك بالله، وعقوق الوالدين، وقتل النفس، وشهادة

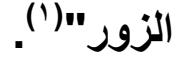

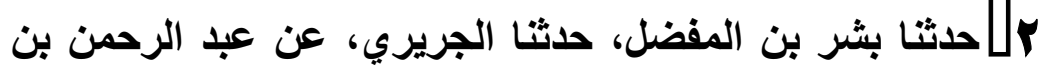

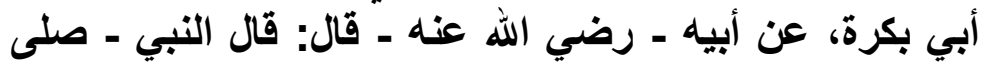

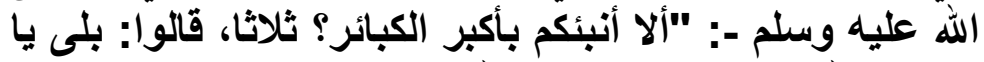

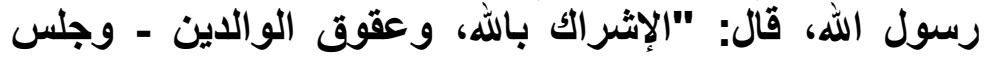

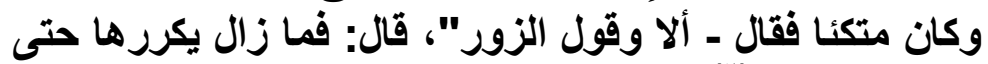

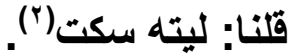
وجه الالاهة من الحديثين:

نبأ الرسول - الحدئن صلى الله عليه وسلم - أصحابه في

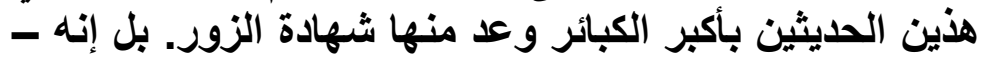

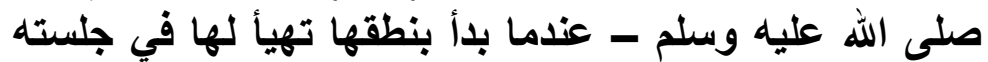
وقام بعد أن كان متكئاً. وهذا دليل على على عظم حرمتها وشئ خطر ها على المجتمع.

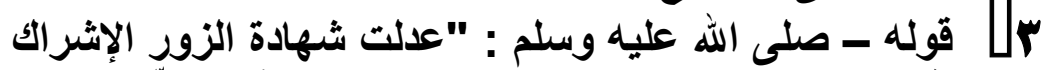

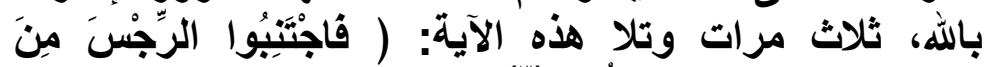

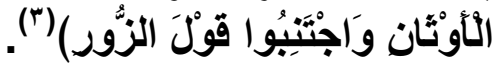
وجه الالالة من الحديث:

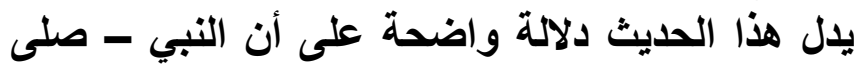

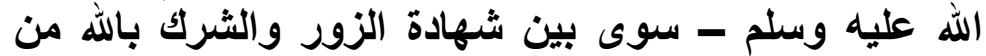
حيث الحرمة والإثم. عله ومئه عالقوله ـ صلى الله عليه وسلم - " لن تزول الإم قدم شاهد الزور

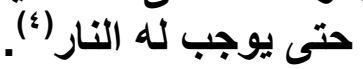

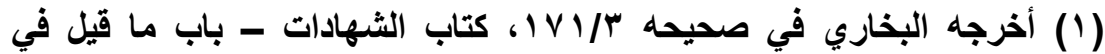

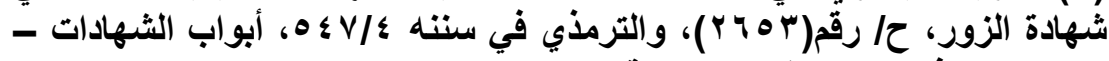

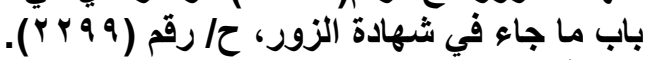

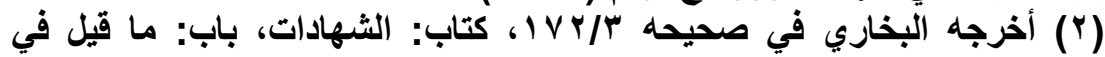

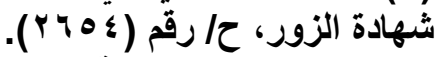

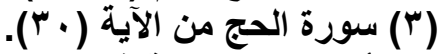

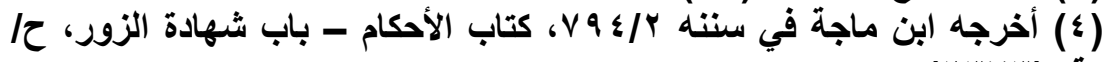

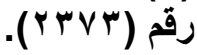


دل الحديث على حرمة شهادة الزور وأن مرتكبه

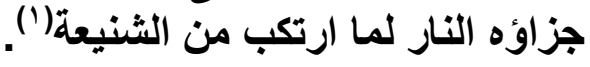

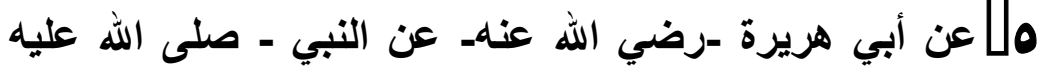

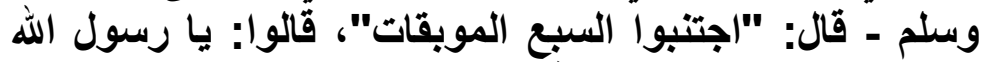

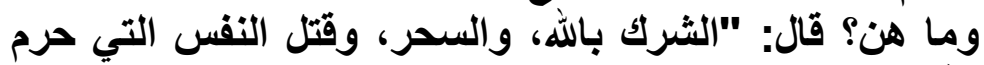

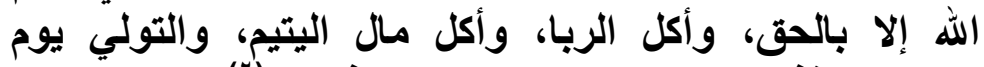

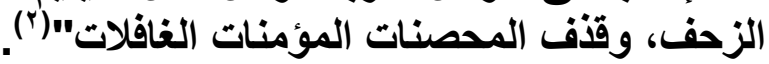

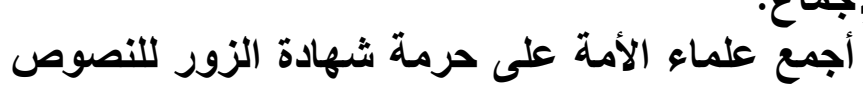

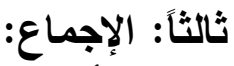

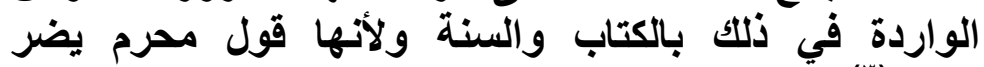

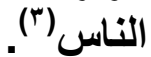

\section{المطلب الثناني}

\section{إنثبات شهادة الزور}

اختلف الفقهاء في كيفية إثبات شهادة الزور إلى أربعة أقوال:

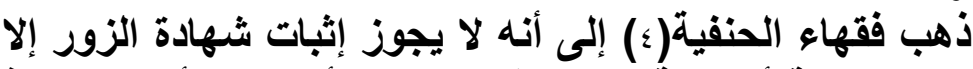

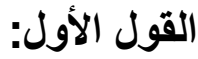

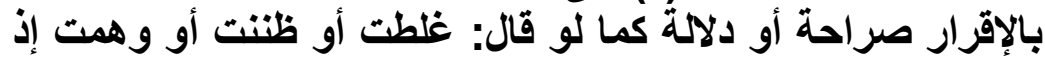

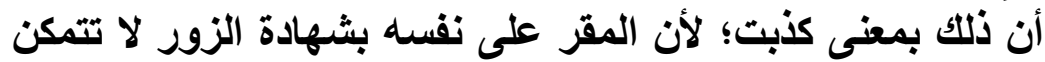

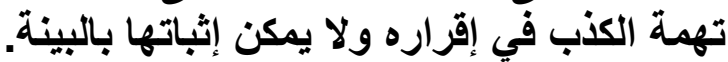

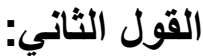

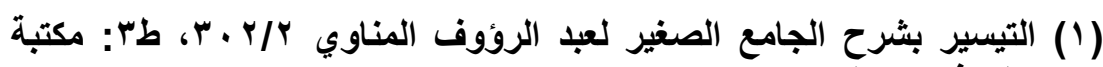

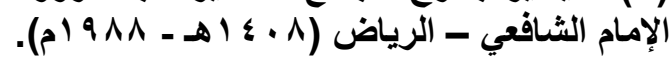

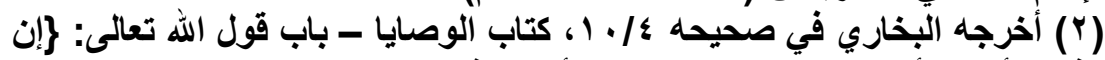

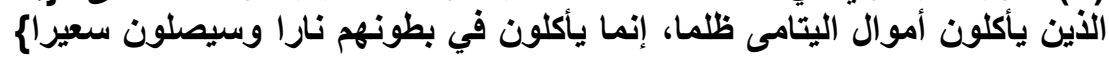

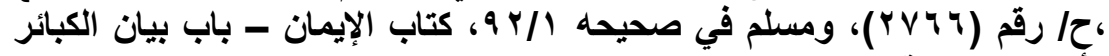

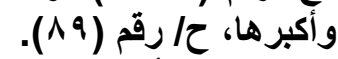

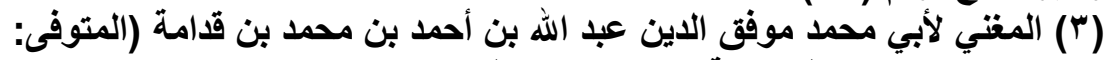

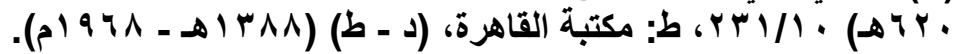

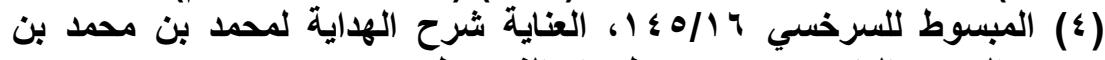

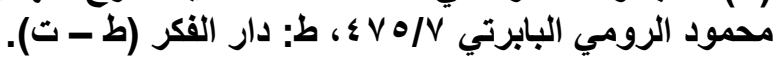


وقد ذهب إليه فقهاء المالكية(1) حيث قالوا لا يعرف شاهد

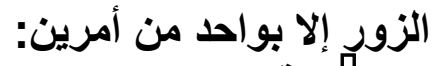

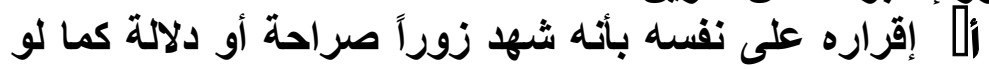

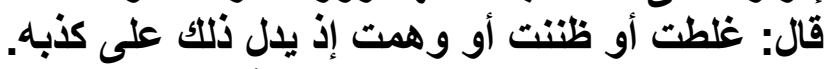

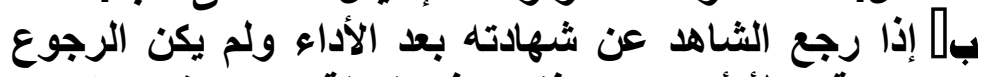

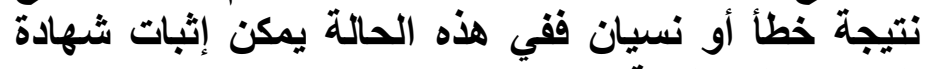

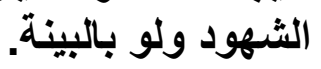

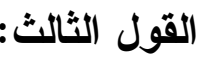

وقد ذهب إليه فقهاء الثافعية(") حيث قالوا: تثبت شهادة

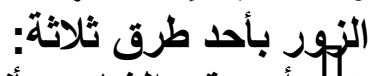

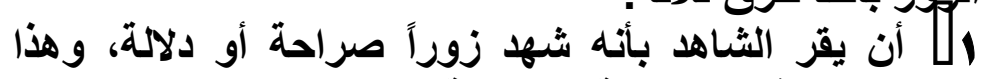
يتفق ومذهب الحنفية والمالكية.

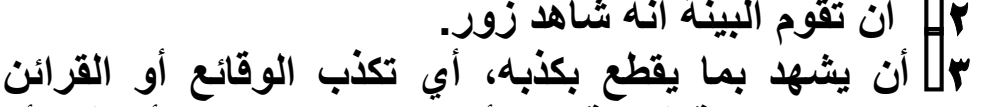

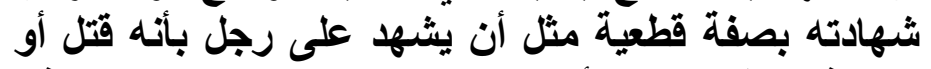

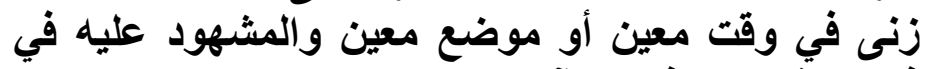
ذلك الوقت كان في بلد آخر.

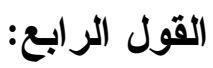

وقد ذهب إليه فقهاء الإمامية حيث قالوا: لا تثبت شهادة

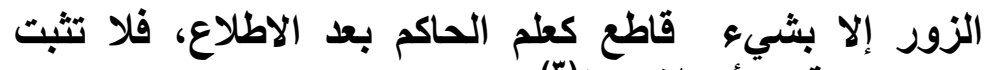

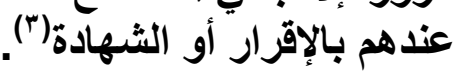

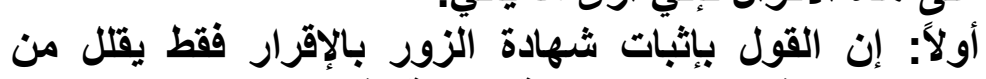

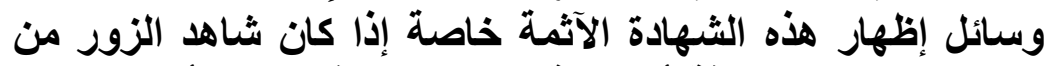
المعتادين عليها كحرفة أو مهنة يقتات منها فلا يمكن أن يقر على الزئ

(1) الجامع لمسائل المدونة لأبي بكر محمد بن عبد الله بن يونس التميمي الصقلي

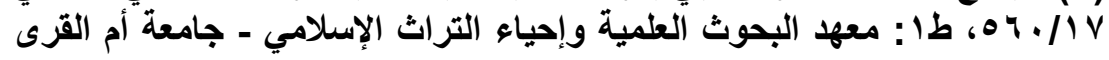

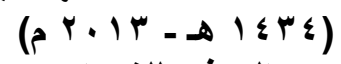

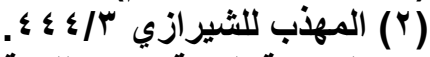

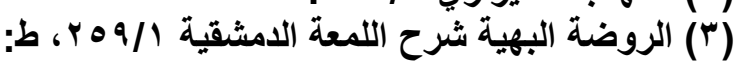


نفسه، فمثل تلكت النوعيات يتحسس طرق الإفلات من العدالة و العقاب الانيوي. ثانياً: لا يجوز القول بأن الثهادة شرعت للإثبات لا للنفي؛ لأن النفي هو إثبات غير الظاهر فيكون إثباتًا. ثُأثاً: أن القول بإثباتها بالبينة فقط - وإن كان يسكهل من

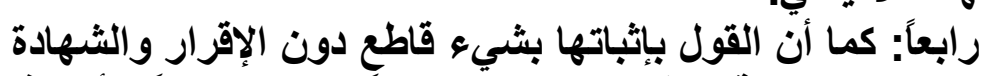

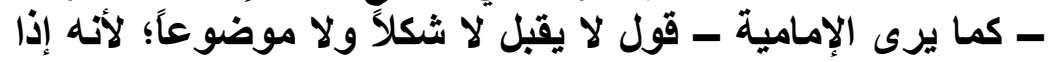
للم يتم الإثبات بالإقرار أو الثهادة فستضيق وسائل الاثبات الأخرى لأنه

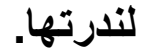
لذا فإني أرى أن يترك السبيل مفتوحاً أمام كافة أدلة الاثبات

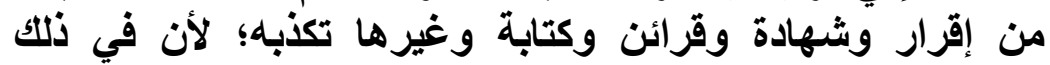

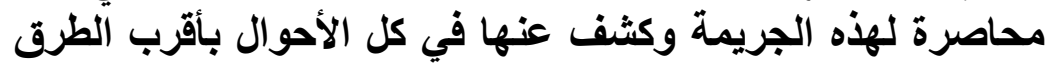

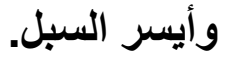

\section{المطاب الثالث}

\section{عقوبة شاهد الزور}

إذا كانت الثريعة الإسلامية لم تضع عقوبة محددة لثاهد

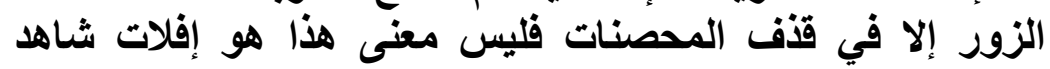

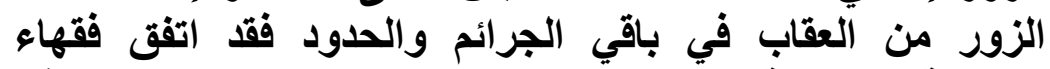

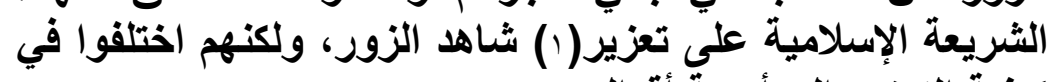
كيفية التعزير إلى أربعة أقوال:

(1) التعزير: عقوبة غير مقدرة وجبت حقاً لله تعالى أو للعبد في كل معصية ليس

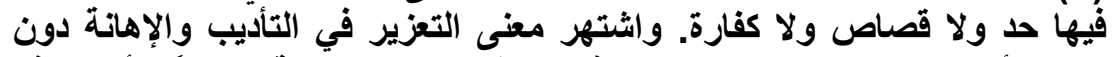

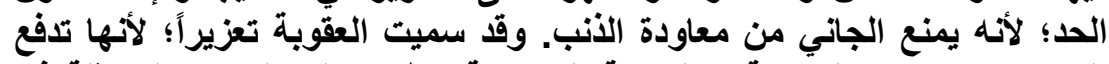

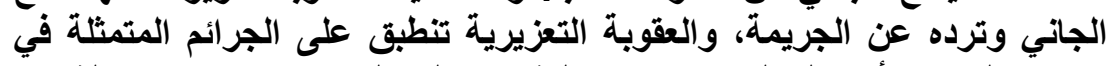

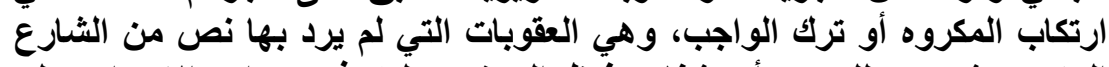

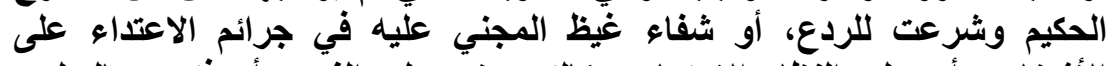

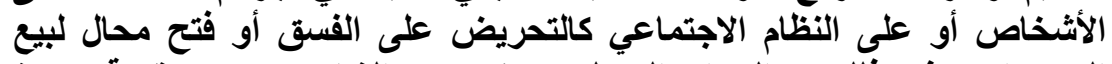

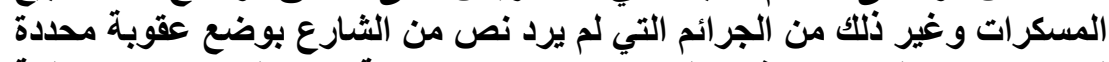

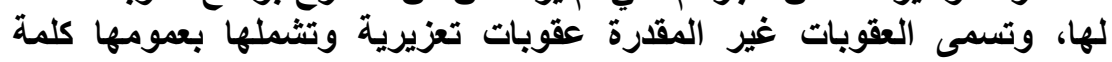

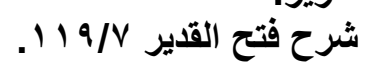




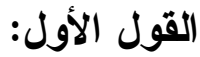

وقد ذهب إليه الإمام أبو حنيفة ـ رحمه الله ـ حيث قال: يعزر

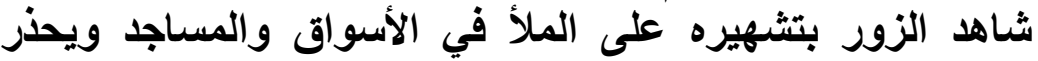

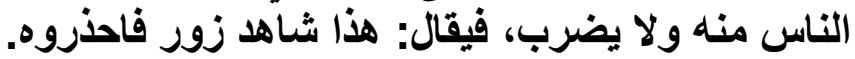

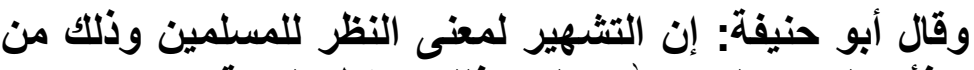

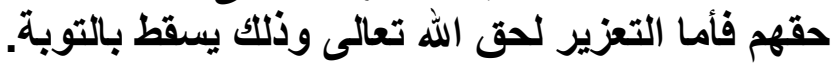

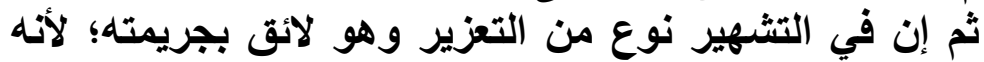

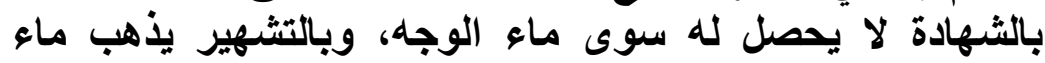

وجهه عند الناس، فكان هذا تعزيراً لايقاً بجريمته فيكتفى بهاه (1).

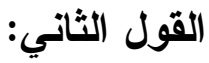

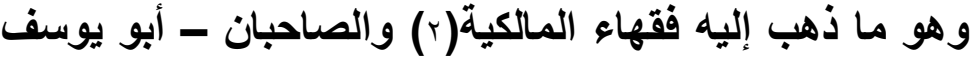

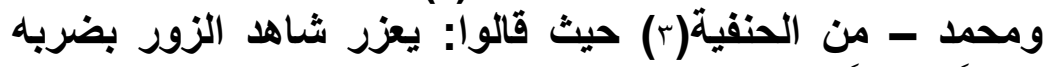

ضرباً موجعاً حتى يكون حديث الناس.

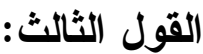

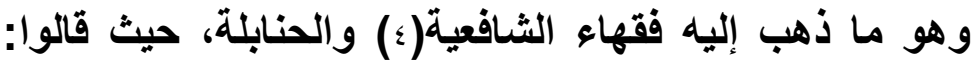

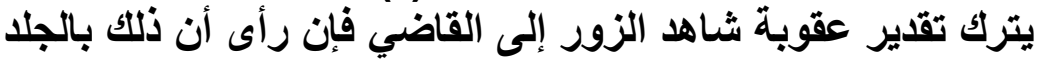

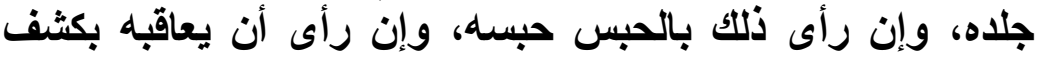
رأسه وإهانته وتوبيخه فعل ذلكا.

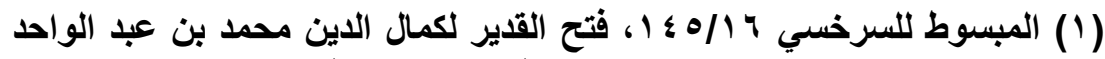

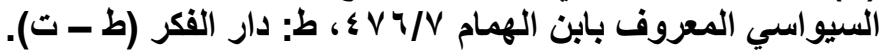
(بار) قال الإمام مالك في شاهل: يضربه القاضي ويطوف به به في المجالس ويضربه

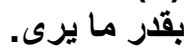
وقال ابن القاسم: وبلغني عن مالك: أنه (شاهل الزور) لا تقبل له شهادة أبداً وإن

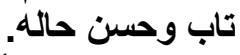

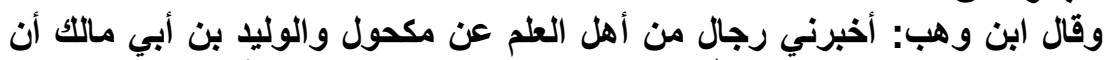

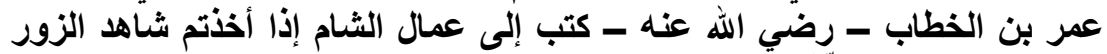

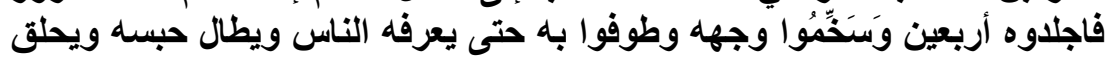

وقال ابن شهاب: أرى أن ينكل بعقوبة موجعة وأن يسمع به حتى يجطوه أحاديث.

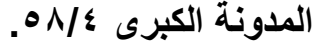

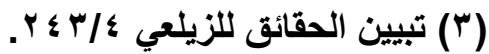

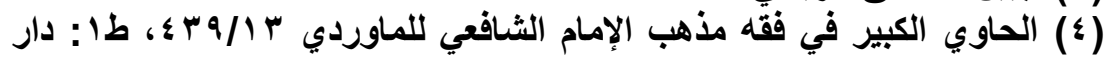

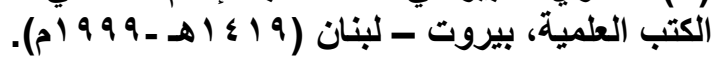


لكن قال فقهاء الحنابلة: إن جلده لا يزيد في جلده على عشر

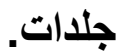
وقال الثافعية: لا يزيد على تسع وثلاثين لئلا يبلغ أدنى وقالز الأوزاعي: في شاهدي الطلاق زوراً يجلدان مائة جلدة

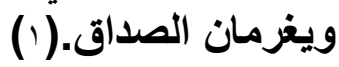

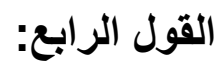

وهو ما ذهب إليه الإمامية حيث قالوا: يجب أن يجلد شاهد

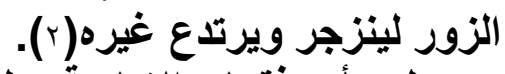

ولم يأت فقهاء الإمامية بلئليل لمذهبهم، ويبدوا أنهم استدلوا

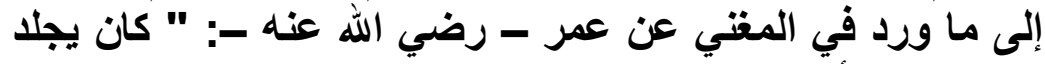

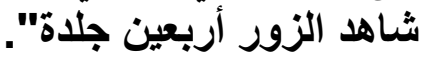

\section{الأدلـــة}

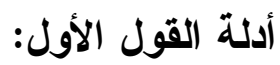

استثل الإمام أبو حنيفة ـ رحمه الله ـ على أن شاهد الزور

يعزر بتثهيره على الملاً في الأسواق والمساجد بالأثر والمعقول:

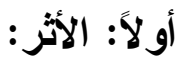

أن شريحاً كان يشهر شاهد الزور ولا يضربه(ب).

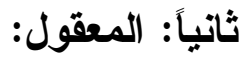

أن الانزجار يحصل بالتشهير فيكتفى بهاه والضرب كان مبالغة

في الزجر ولكنه يقع مانعاً عن الرجوع فوجب التهار التخفيف نظراً إلى

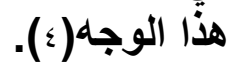

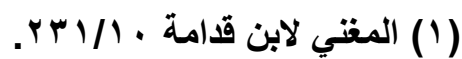

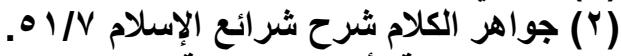

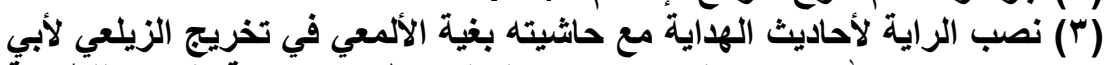

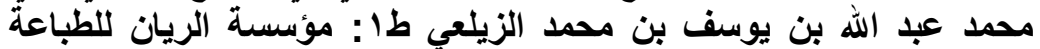

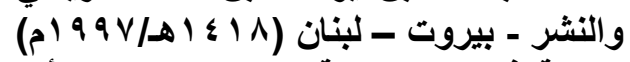

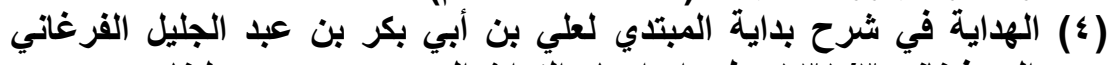

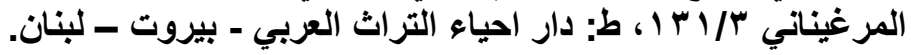


أدلة القول الثاني: - أنقاء

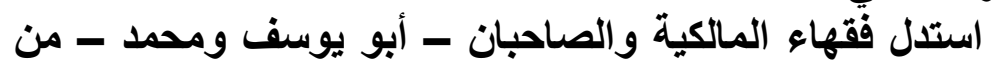

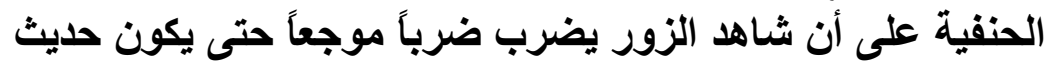

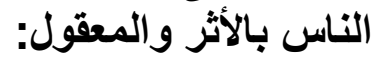

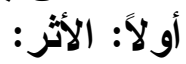

أن عمر بن الخطاب ـ رضي الله عنه ــ ضرب شاهد الزور

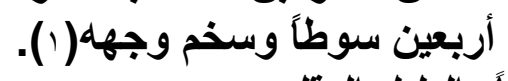

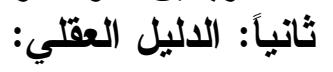

شهادة الزور كبيرة يتعدى ضررها إلى العباد، وليس فيها حد

مقدر شرعاً يلتزم القاضي بهأ(ب).

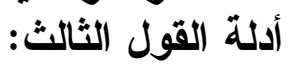

استال فقهاء الثافعية والحنابلة على ترك تقدير عقوبة شاهد

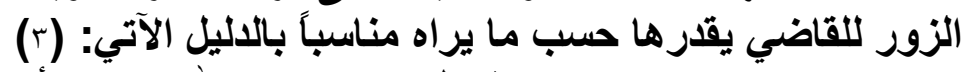

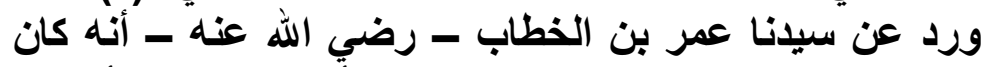
يعزر شاهد الزور بالتشهير، كما روي عنه أنَه كان يجلده أربعين جلدة ويسخم وجها ويطال حبسه (؛ ).

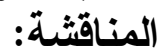

بعد ذكر أقوال الفقهاء وبيان أدلتهم في كيفية تعزير شاهد الزور فإني ألاحظ الآتي:

1. أن القول بالاكتفاء بتثهير شاهد الزور - كما يرى أبو حنيفة

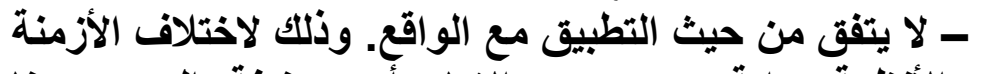

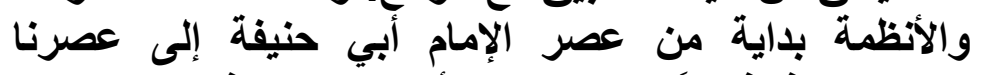

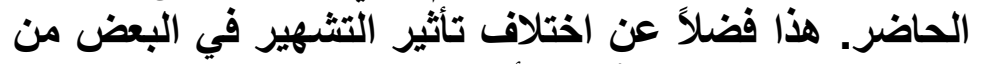

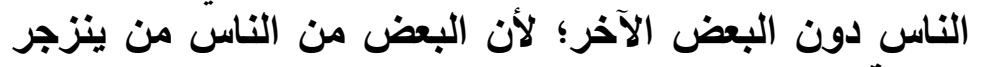

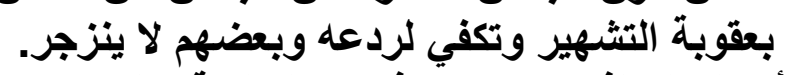

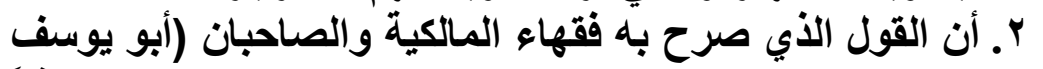
ومحمد) القائل بتعزير شاهد الزور بالضرب الصاء لا يعتبر كافياً

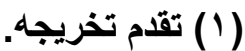

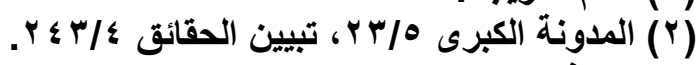

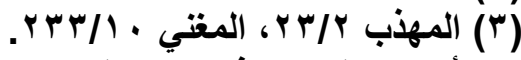

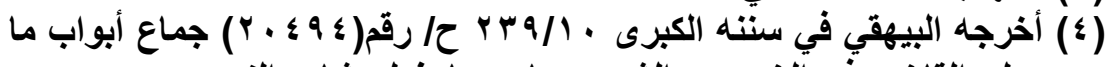

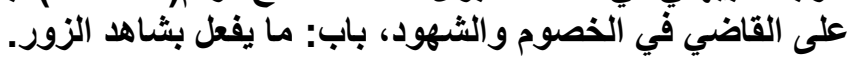


لعقوبة شاهد الزور إذ يصطدم بأمور أخرى تعترضه، مثل: أن أن

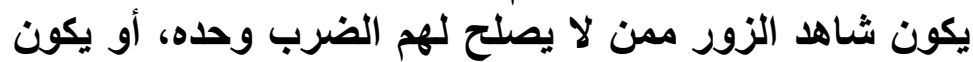

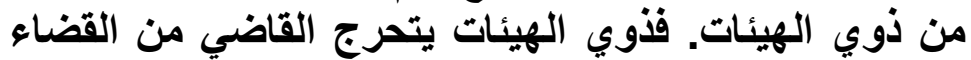

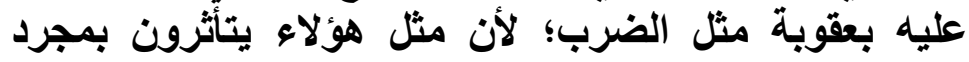

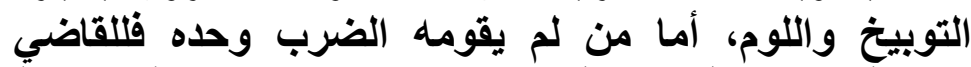
السلطة التقليرية الكاملة في تقاير ما يراه زاجراً ورادعاً لنهؤلاء.

r. أن القول الصادر من الثيعة الإمامية باعتبار عقوبة التعزير

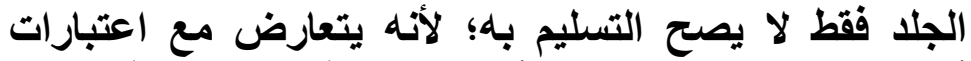

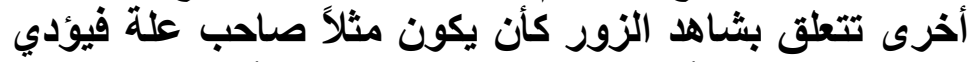

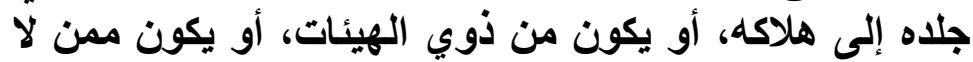

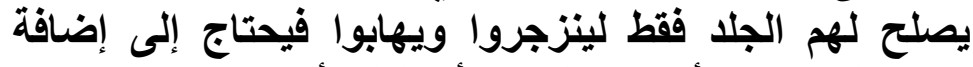
بعض العقويات الأخرى كالحبس أو النفي أو الإبعاد.

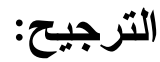

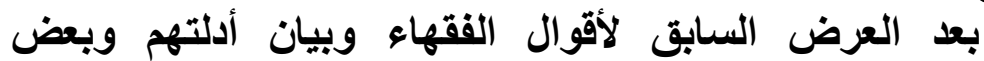

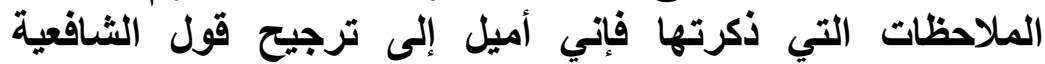

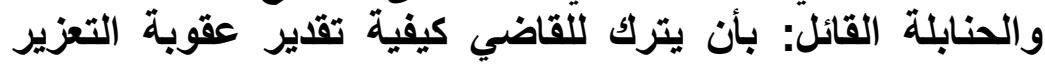
حسب ما يراه وظروف الثخص المعزور؛ لأن القاضي أعلم بمان و هذا القول أولى بترجيحه على غيره من الأقوال الأخرى وذلك

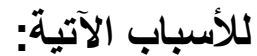

1. أنه أعطى للقاضي حرية التقدير حسب ظروف كلئه كل شخص وما تتطلبه نوعيته وتكوينه ومركزه الأدبي من عقوبة ئلة

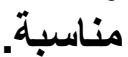

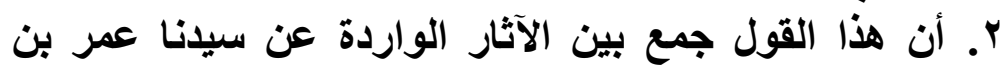

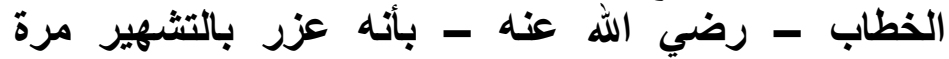

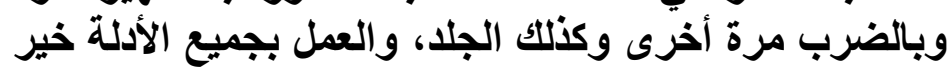

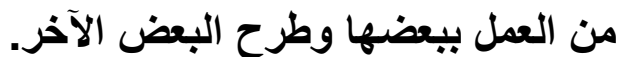

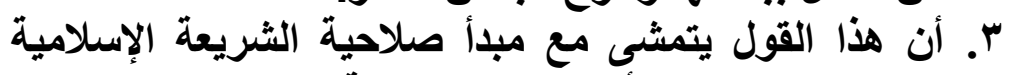

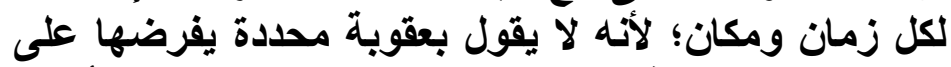

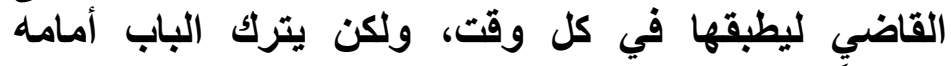
مفتوحاً لكل اجتهاد حسب كل زمن. 
؛. أرى من وجهة نظري الخاصة: أن تكون العقوبة التعزيرية

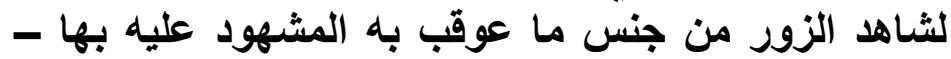

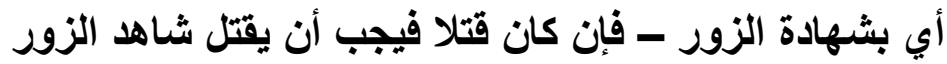

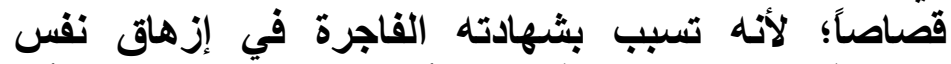

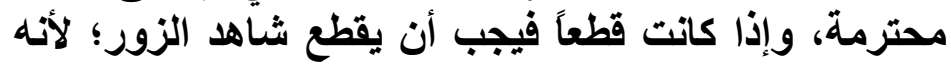

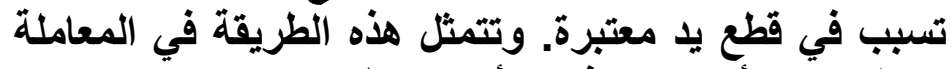

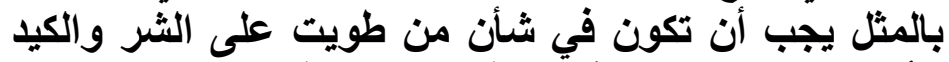
لكلأبرياء لغرض دنيء أو غاية غير شريفة.

ويؤيد ذلكك: للايريا

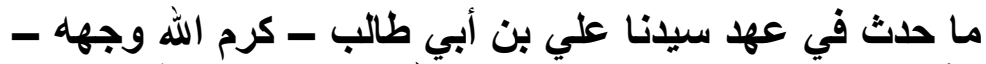

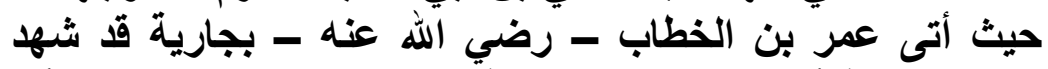

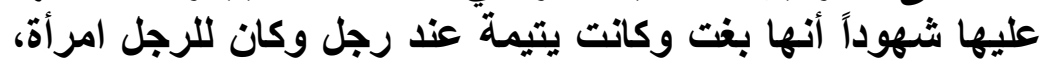

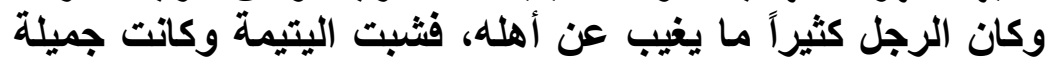

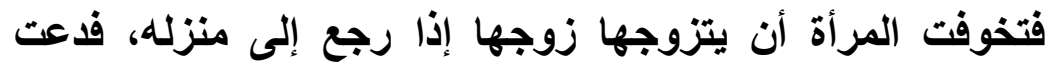
بنسوة من جيرانه فأمسكنها ثم افتضتها بإصبعها فئها فئما قدم زوجها

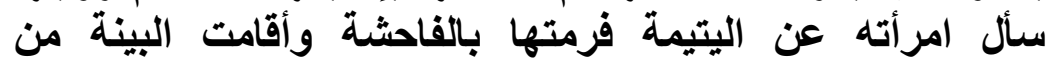

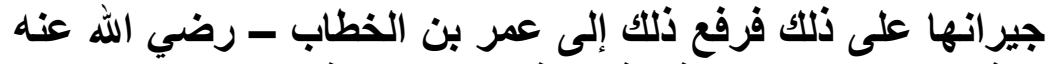

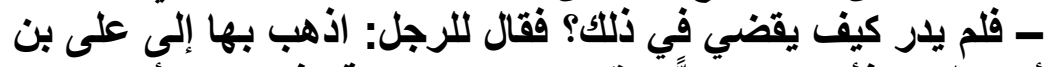

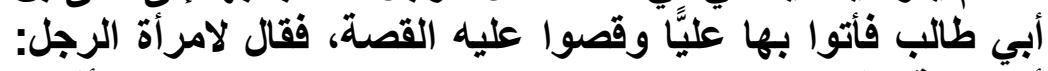

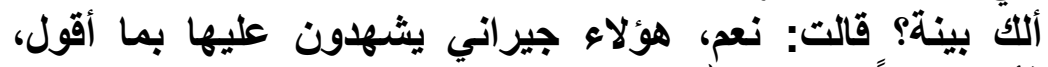

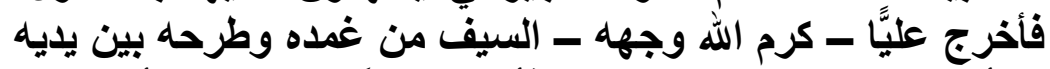

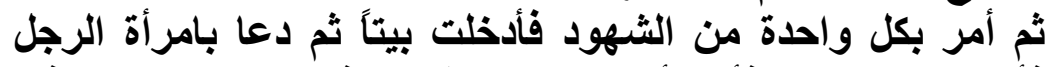

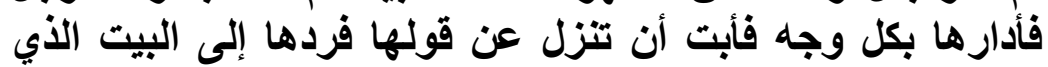

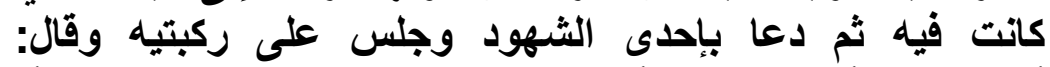

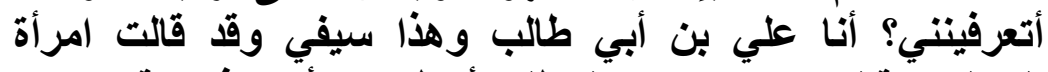

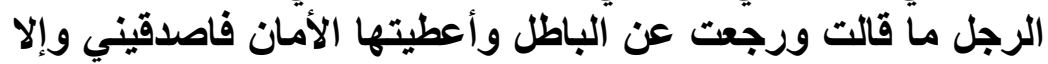

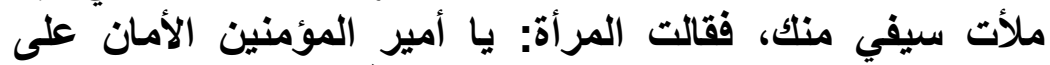

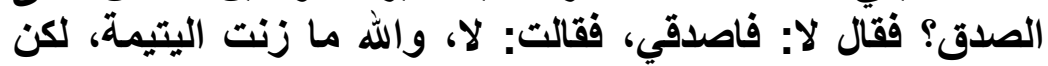

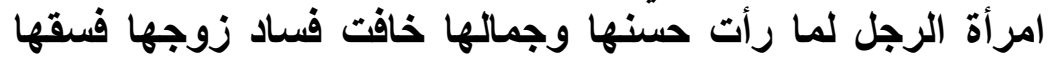

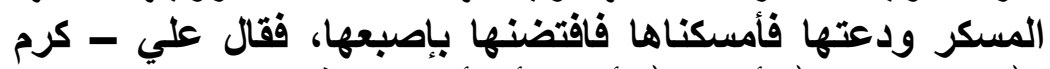

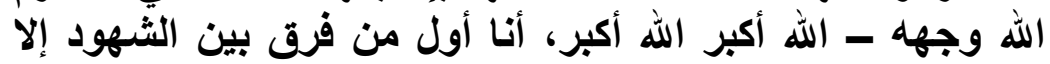

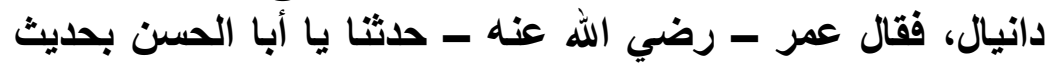
دانيال النبي عليه السلام، فقال علي: إن دانيال كان غلاماً يتيماً 


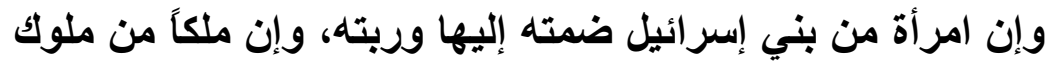

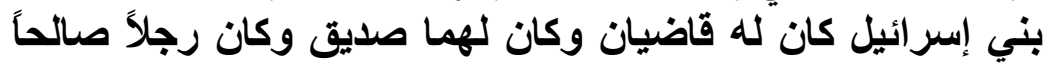

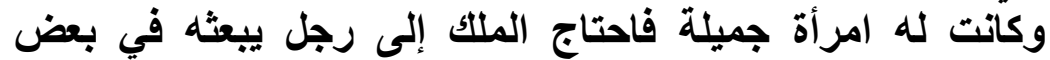

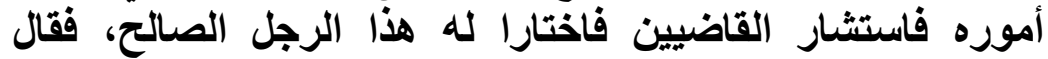

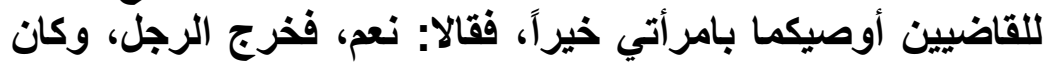

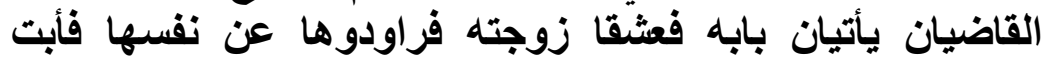

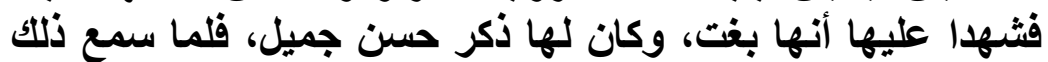

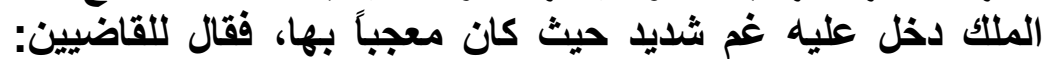

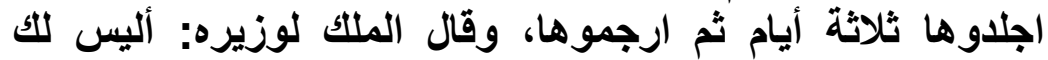

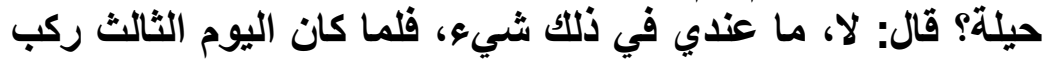

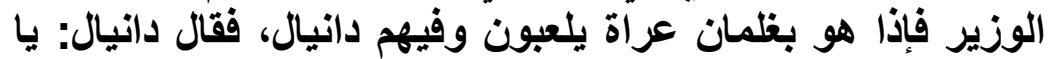

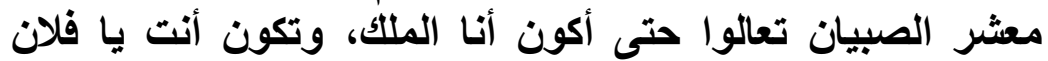

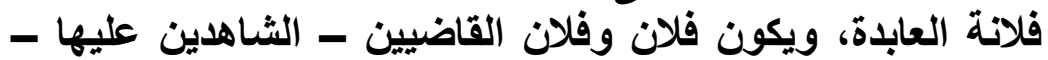

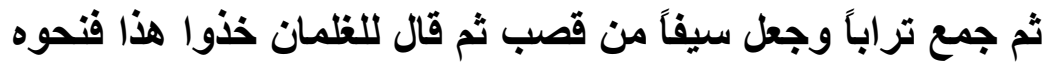

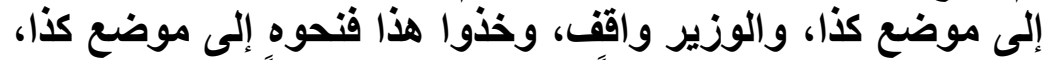

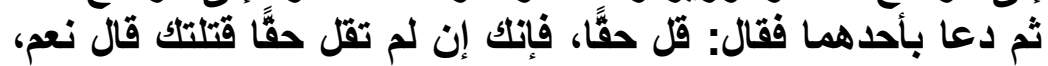

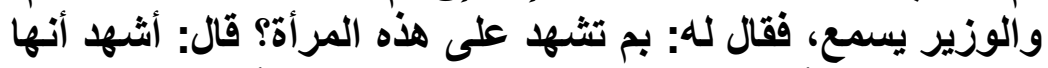

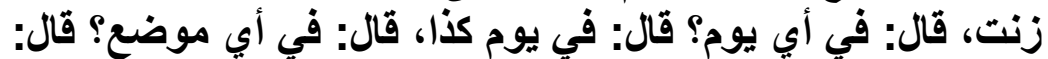

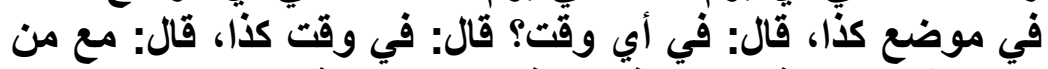

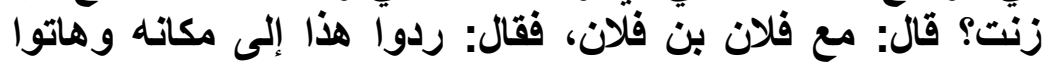

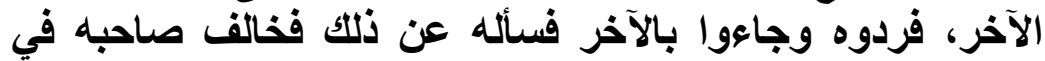

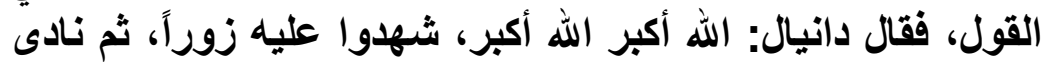

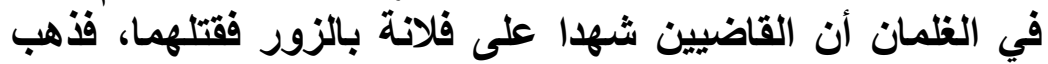

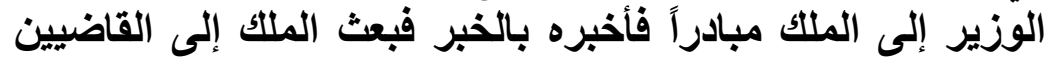

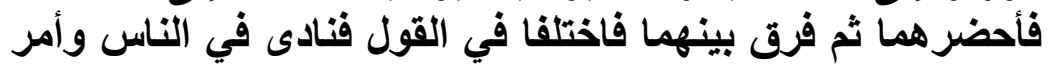

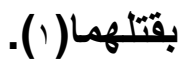

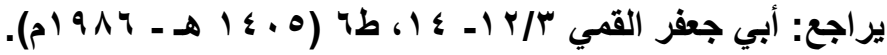

$$
\begin{aligned}
& -1 \leqslant 9-
\end{aligned}
$$




\section{المبحث الثالث \\ الآثار المثرثبة على الحكم بشهادة الزور الزمبر

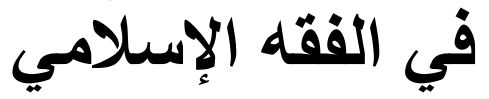

المطلب الأول: الأثر المترتب مطلب على إقامة الحدود في شهادة الزيشتب الزولى خمسة مطالب: الأبثر المطلب الثاني: الأثر المترتب على القصاص بشهادة الزبادور.

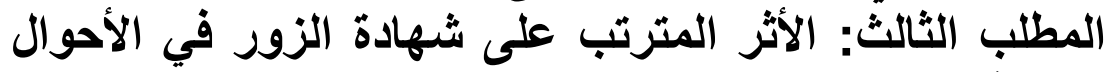
المطلب الرابع: الأثر المترتب على شهادة الزور في الأحوال

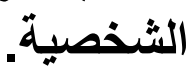
المطلب الخامس: الأثر المترتب على الإكراه في شهادة الزور. 


\section{المطلب الأول}

\section{الأثر المتر تب على إقامة الهدود فيى شهادة الزور}

الحدود هي ما كاتت عقوبتها حقَّا لله تعالى، فلا يجوز التنازل

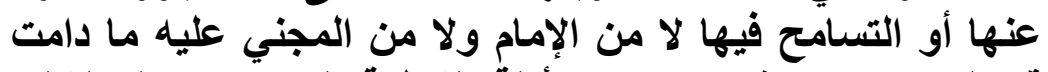

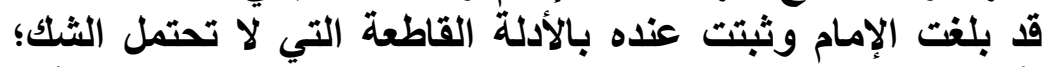

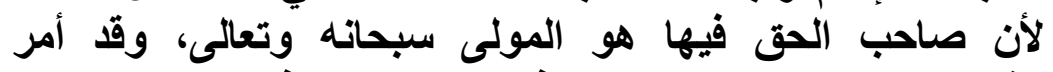

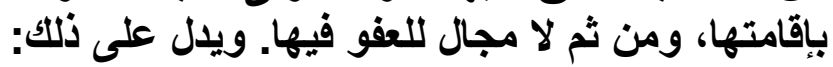

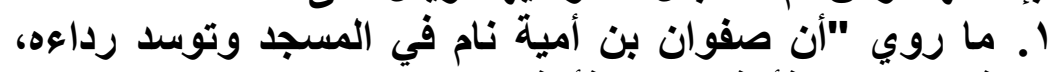

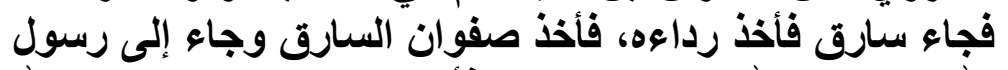

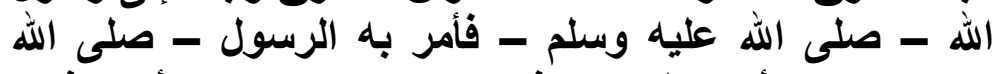

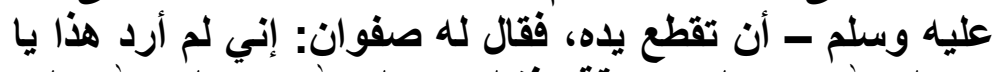

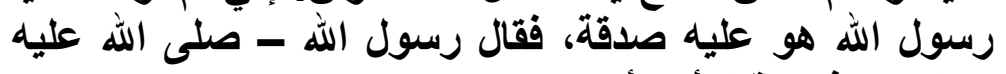
وسلم -: فهلا قبل أن تأتي بهله" (1).

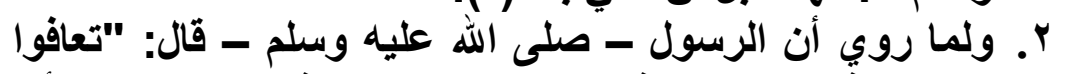

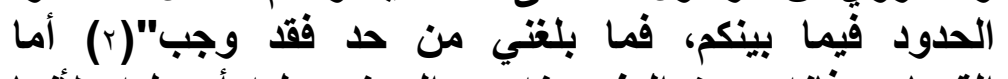

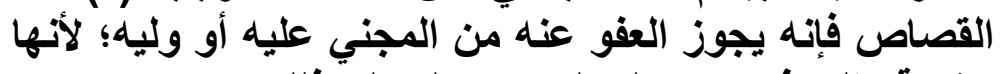

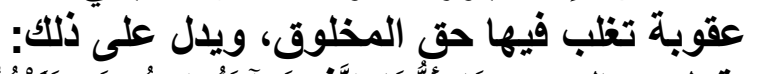

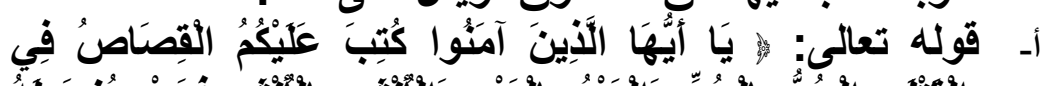

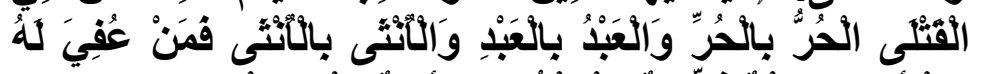

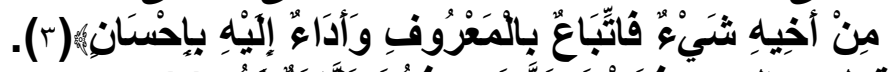

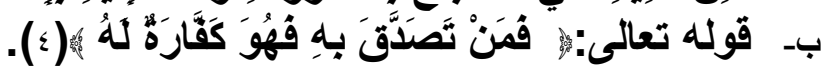

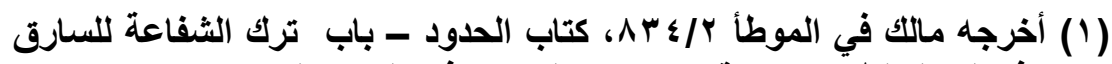

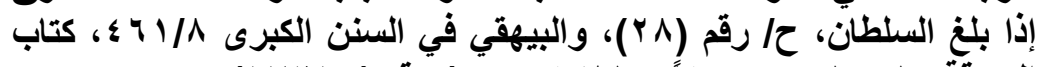

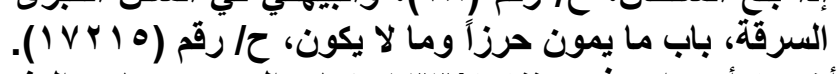

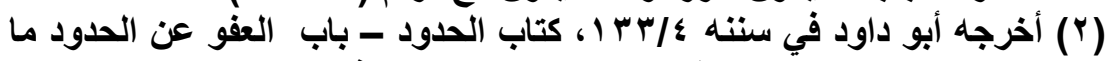

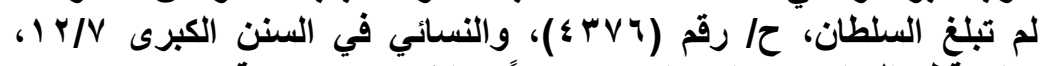

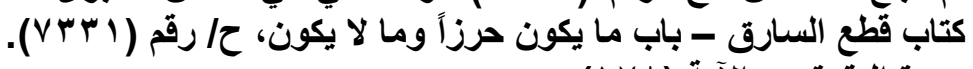

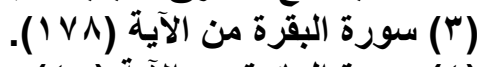

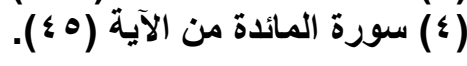


ج- قوله ـ صلى الله عليه وسلم -: " من قتل له قتيل فهو بخير

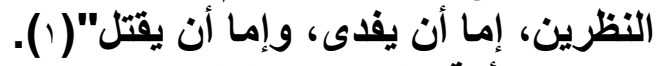

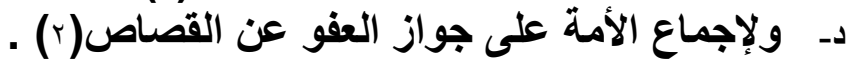

وتتمثل الحدود في حد الزنا، وحد السرقة، وحد الثرب، وحد القذف:

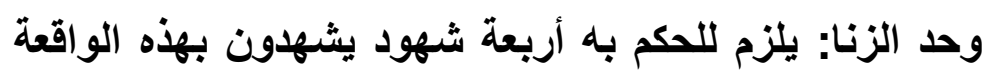

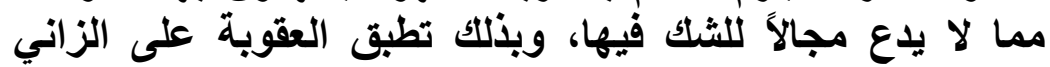

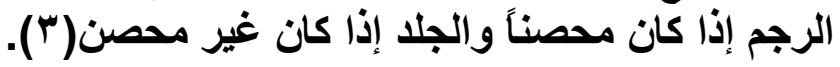

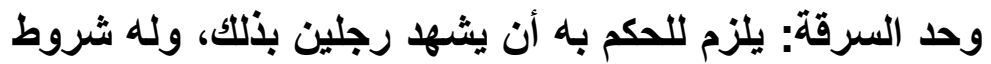

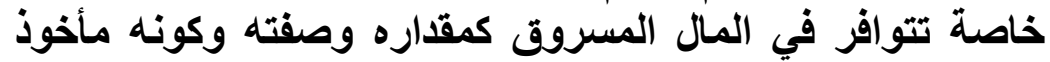
من حرز مثله وغير ذلك من الشروط حتى يتمكن القاضي من

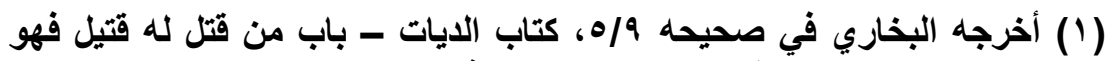

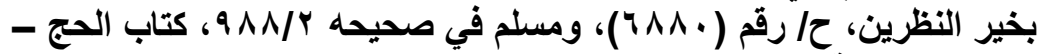

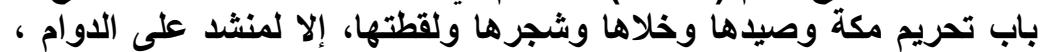

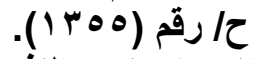

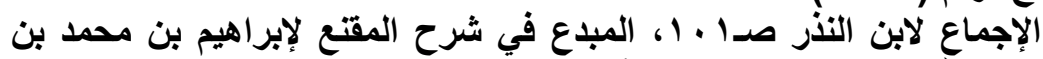

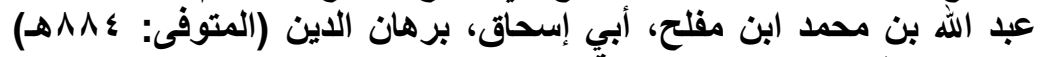

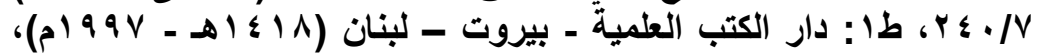

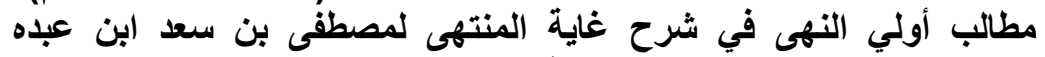

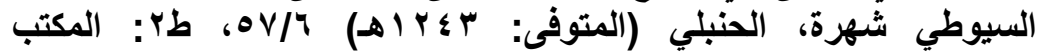

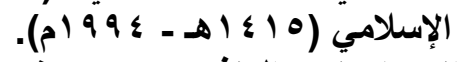

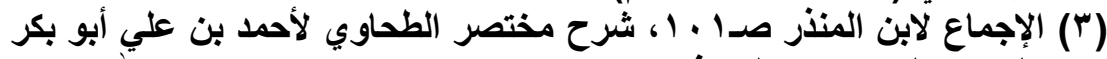

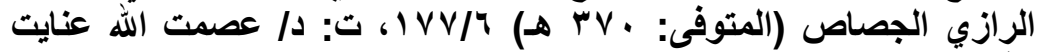

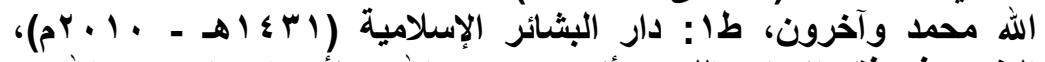

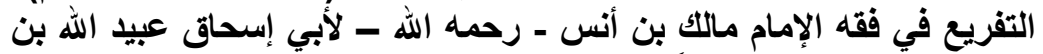

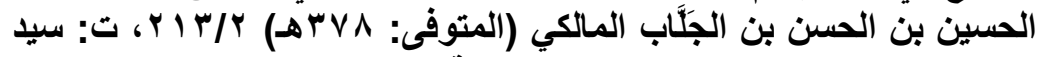

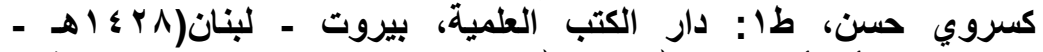

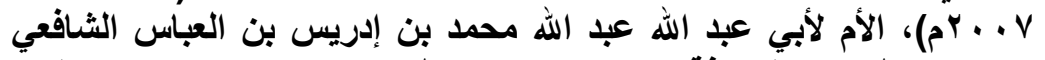

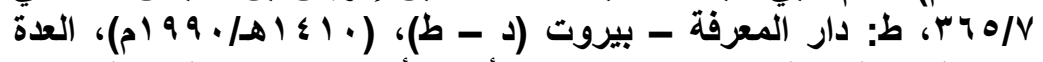

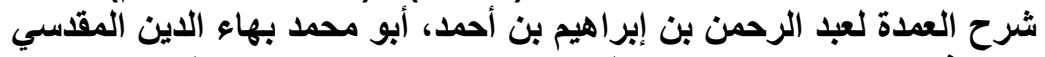

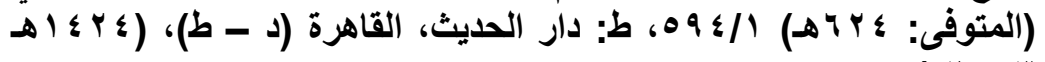

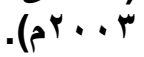


الحكم على السارق وتطبيق الحد عليه وهو القطع (1) ).

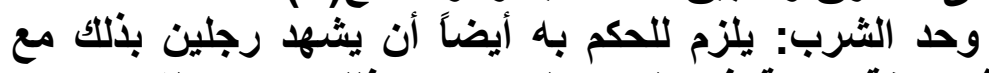

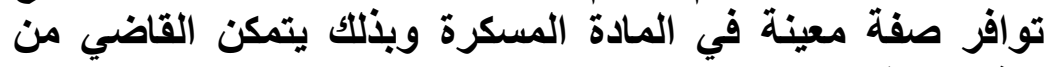

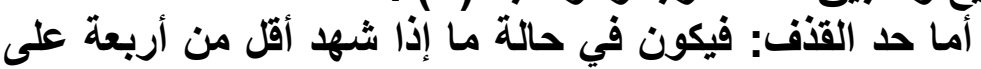

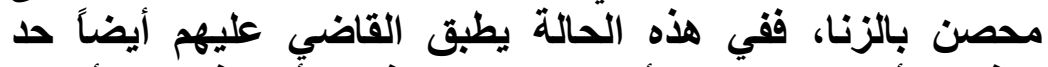

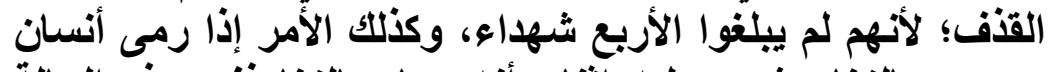

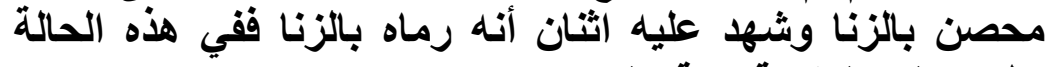
تطبق عليه العقوبة مائة جلاة (بآ).

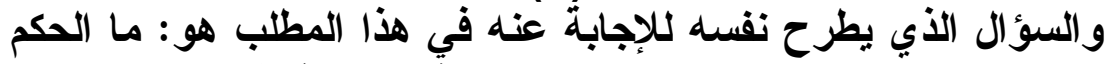

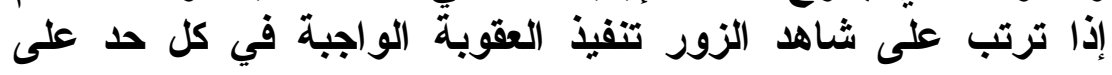

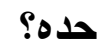

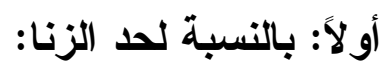

اتفق الفقهاء على أن العقوبة المطبقة في حد الزنا إذا كانت هي الجلد مائة جلدة وذلك في حالة ما إذا كان من شهر علية لئه بالزنا

البلغة السالك لأقرب المسالك المعروف بحاثية الصاوي على الثرح

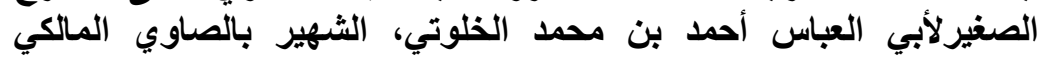

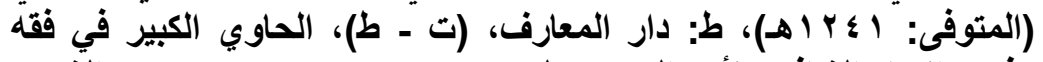

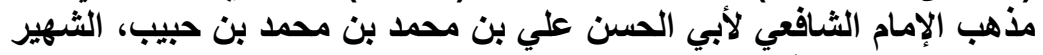

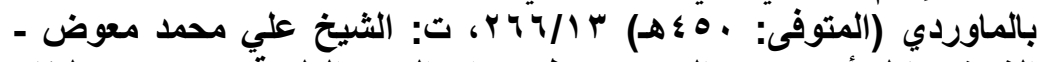
الثيخ عادل أحمد عبد الموجود، طا: دار الكتب الطمية، بيروت - لبنان

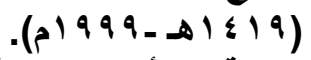

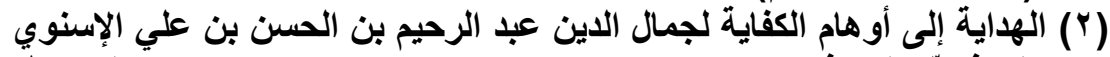

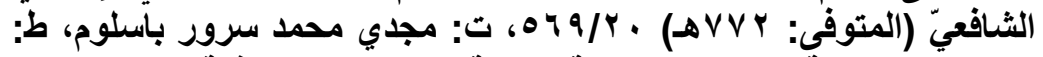

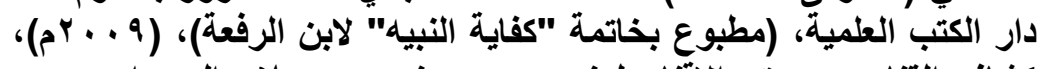

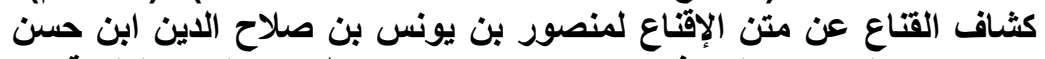

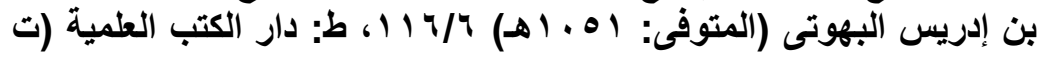
. (b("آ) تحفة الفقهاء لأبي بكر علاء الاين محمد بن أحمد بن أبي أحمد السمرقندي

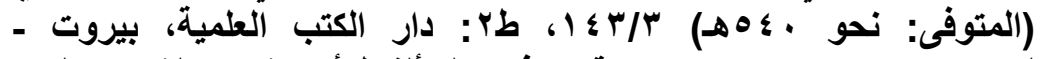

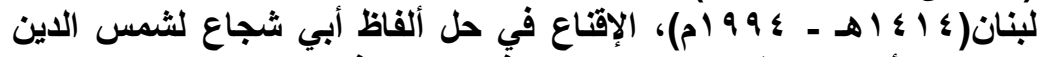
محمد بن أحد الخطيب الثربيني الثافعي (المتوفى: مكتب البحوث والاراسات ـ دار الفكر، ط: دار الفكر - بيروت، (ت - ط). 
غير محصن( (1) فإنه في هذه الحالة إذا تم استيفاء العقوبة وتبين

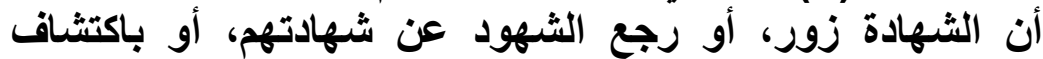

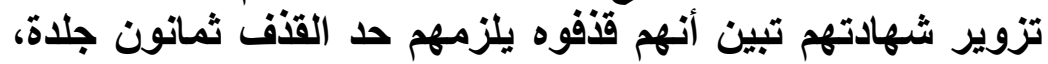
ويدل على ذلك الكتاب والسنة والإجماع.

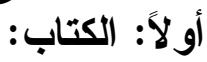

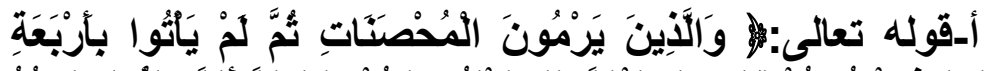

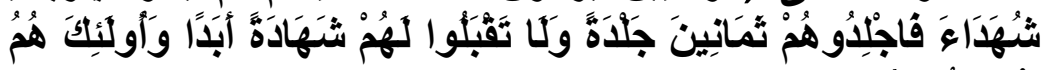

والمعنى: أن من قذف مسلماً أو مسلمة ولم يستطع إقامة البينة

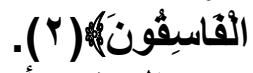
المطلوبة لإثبات قوله فهو كاذب عند الله، أي حكمه في شريعة الله - عز وجل- حكم الكاذب فيقام عليه الحدا.

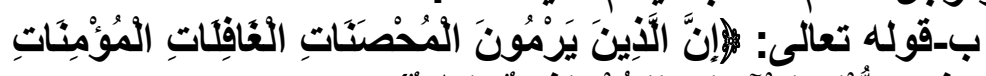

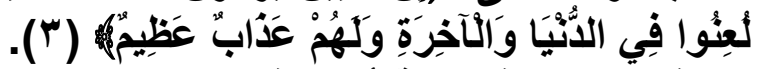

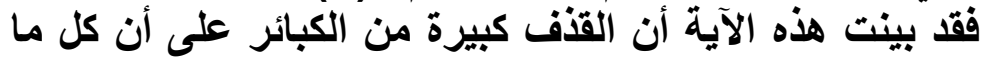
توعد عليه باللعن أو العذاب أو شرع فيه حد فهو كبيرة( ) ).

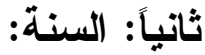

ما روي عن أبي هريرة - رضي الله عنه ـ عن النبي صلى الله

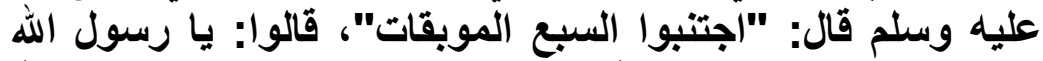

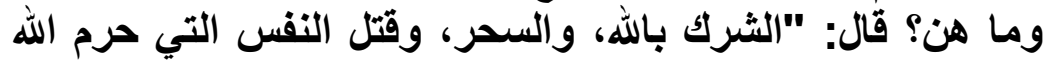

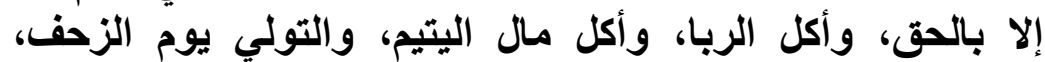

وقذف المحصنات المؤمنات الغافلات" (0). وجه الدلالة من الحديث:

أن الرسول - صلى الله عليه وسلم - وضع قذف الفت المحصنات

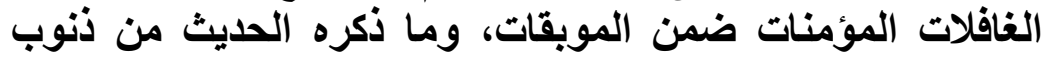

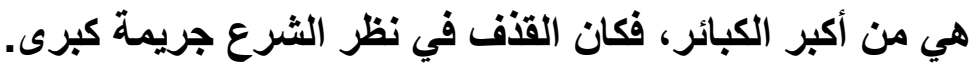

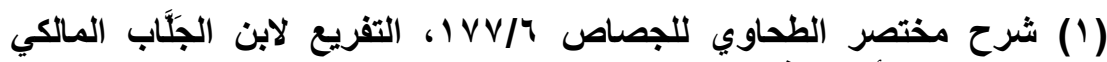

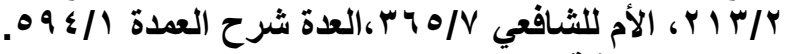

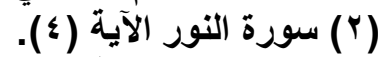

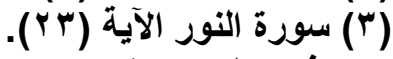

(؛) فتح الباري شرح صحيح البخاري لأحمد بن علي بن حجر أبي الفضل

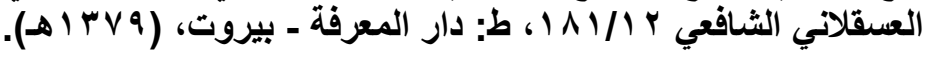

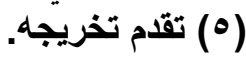


ب-قال عليه الصلاة والسلام: "من قذف ذميا حد له يوم القيامة

بسياط من نار" (1). - (1).

فذل هذا الحديث على أن المسلم له أن يحفظ لسانه ويصونه

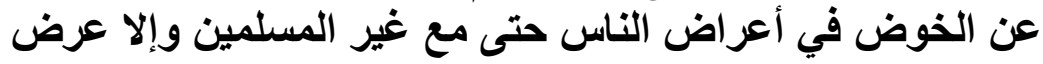

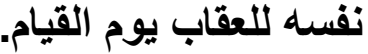

أجمعت الأمة الإسلامية من لان الرسول - ـ صلى الله عليه

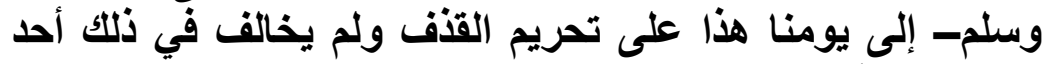
فكان إجماعأ (Y). وتطبيق هذه العقوبة سواء كان الرجوع قبل الحكم أو بعده، وسواء كثف تزوير الشهادة قبل الحكم على أنه زنى أم بعد الحكم الحم

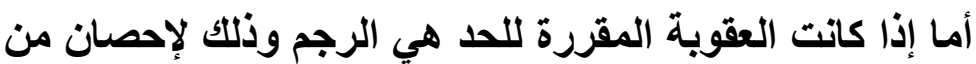
شها عليه بالزنى فقد اختلف الفقهاء في هل تؤخذ منه الدية أم قال ابن قدامة في الثرح الكبير: "وحد شهود الزنا الراجعون

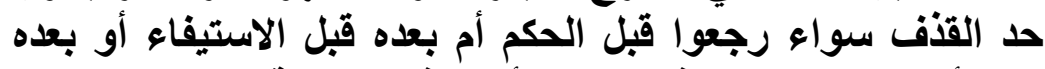

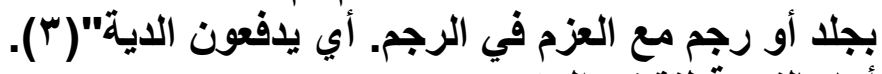

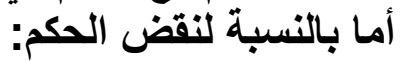
فإذا تبين تزوير الثهادة أو رجع الثهود قبل استيفاء الحكم

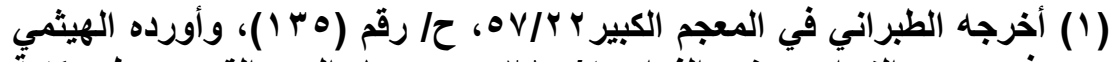

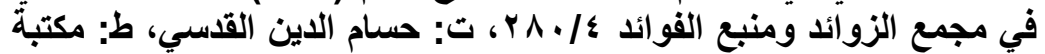

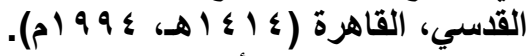

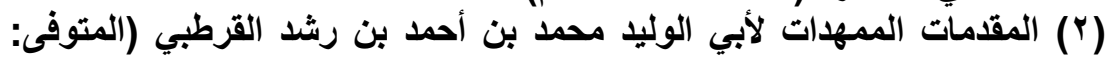

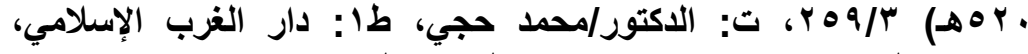

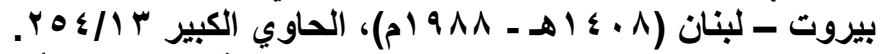

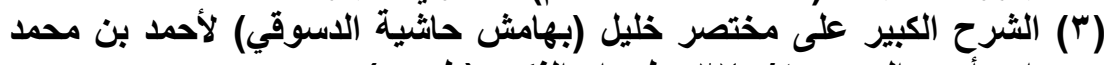

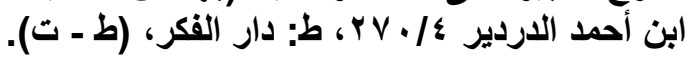


فإن الحكم ينقض إن أمكن ذلك (1)

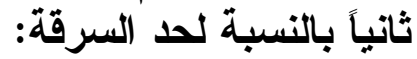

تعل جريمة السرقة من الكبائر التي حرمتها الثريعة الإسلامية،

ويلال على تحريمها الكتاب والسنة والإجماع:

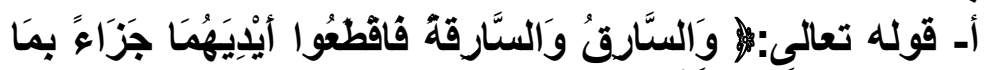

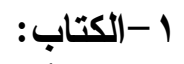

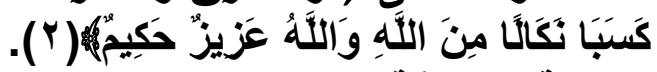

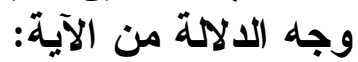

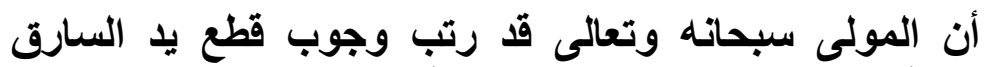
و السارقة على سرقتهما، وهذه العقوبة الثديدة لا تكون إلا على بلى العيد فعل محرم شرعاً.

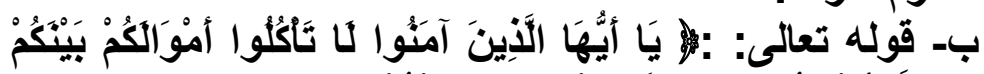

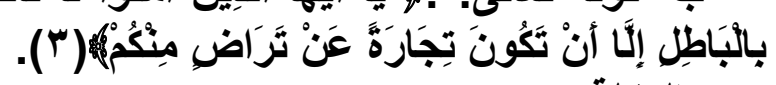

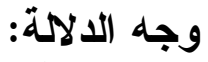

أن الله سبحانه وتعالى نهى عن أكل أموال الناس بالباطل،

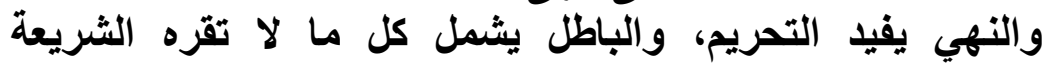

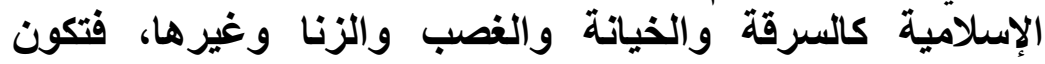

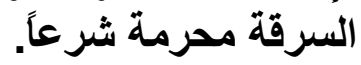

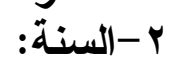

أـ عن أبي هريرة، عن النبي - صلى الله عليه وسلم ـ قال: "لعن الله السارق، يسرق البيضة فتقطع يده، ويسرق الحبل فتقطع

(1) باية المبتاي في فقه الإمام أبي حنيفة لطي بن أبي بكر بن عبد الجليل

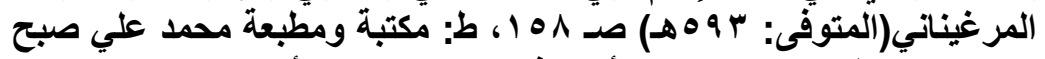

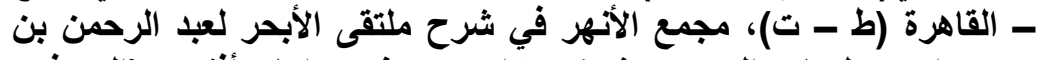

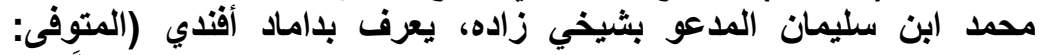

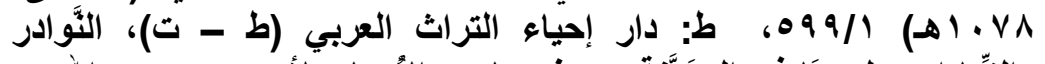

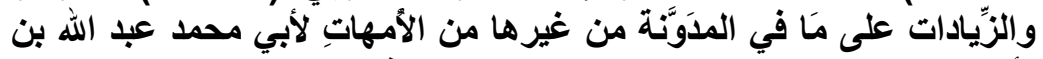
(أبي زيد) عبد الرحمن= =القيرواني، (المتوفى:

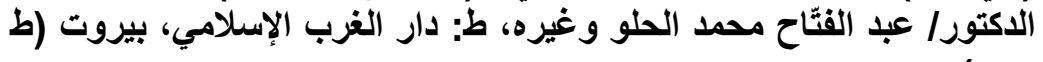
. ت (r)

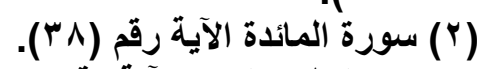

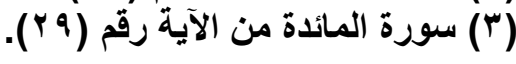




$$
\text { وجه الدلالة: (1). }
$$

هذا الحديث يذل بوضوح على حرمة السرقة لورود اللعن، واللعن لا يكون إلا إذا كان الفعل محرماً شرعاً.

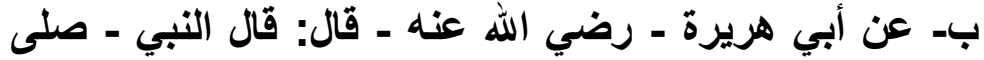

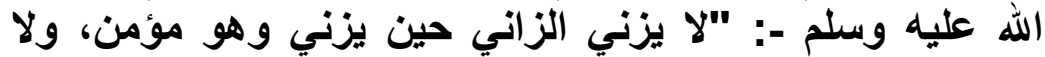

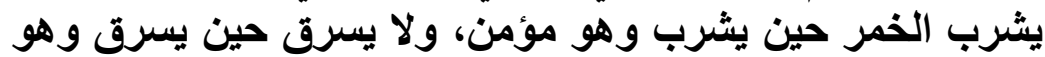

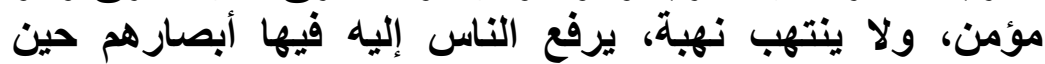

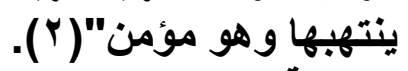

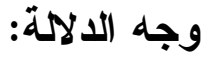

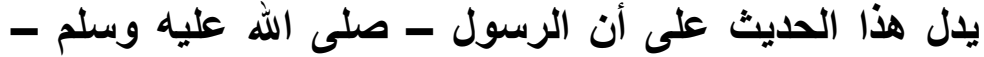

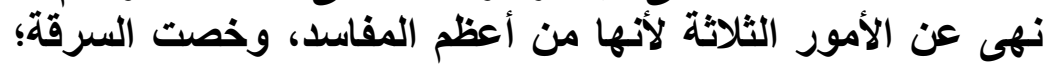
لأنها أغلب الوجوه التي يؤخذ بها مال الغنا الغير بغير حق.

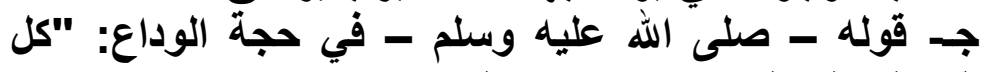
المسلم على المسلم حرام، دمه، وماله، وعرضه" (َّ).

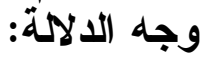
هذا الحديث يال على حرمة النفس والمال والعرض، فالسرقة حرام؛ لأنها اعتداء على حقى الغير.

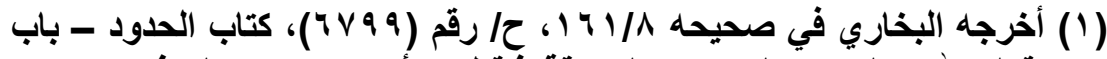

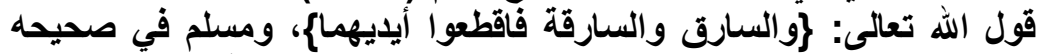

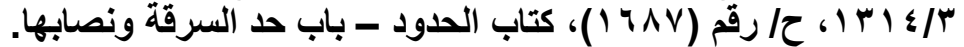

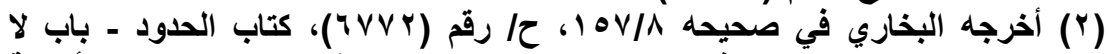

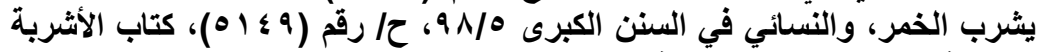

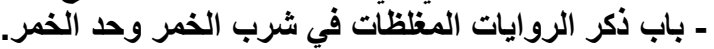

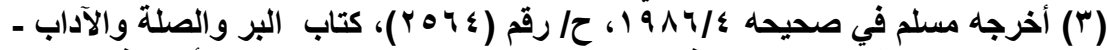

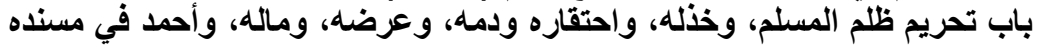

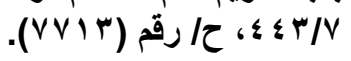


با أما الإجماعاع) أما الإجماع( (1) فقد أجميع فقهاء الشريعة الإسلاميه مع اختلاف

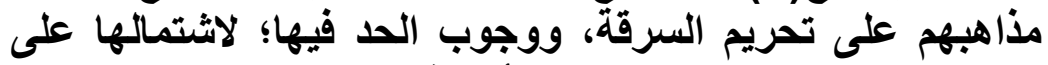

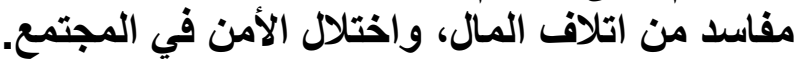

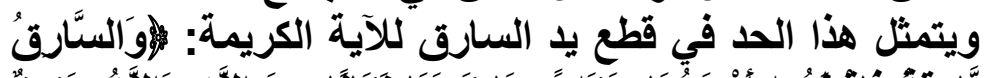

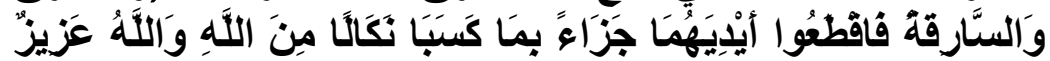

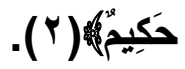

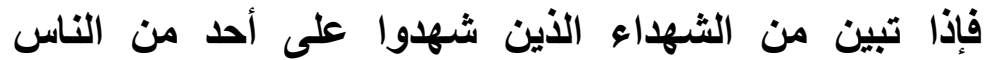

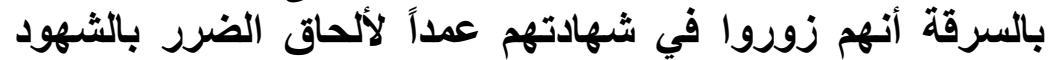

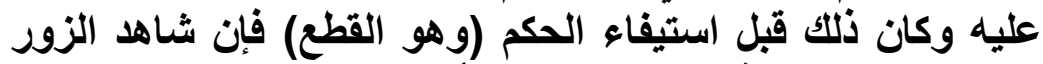

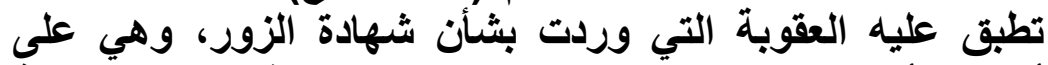

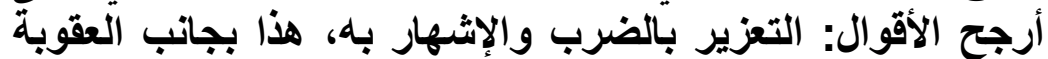

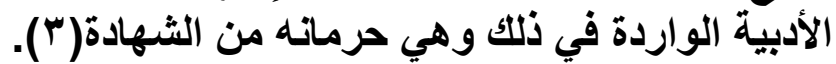

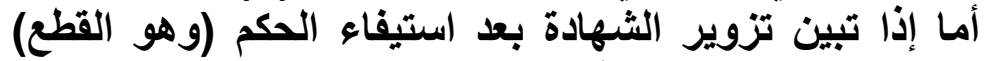
فقد اختلف الفقهاء في عقوبة شاهد الزور بلى على قولين:

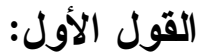

إذا كان الثاهدان قد رجعا وقالا في رجوعهما لقد تعمدنا

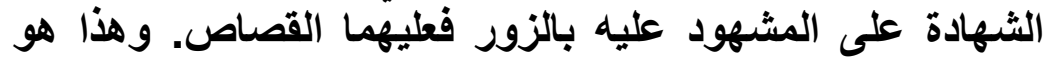

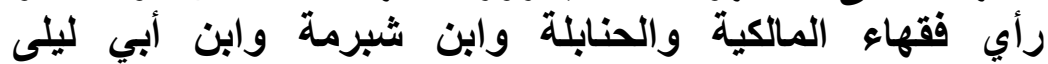
والأوزاعي والشافعي وأبو عبيد(أحنابلة وابن .

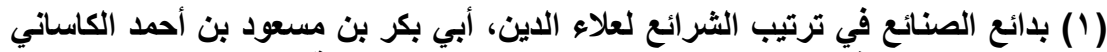

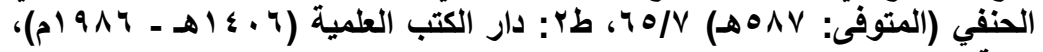

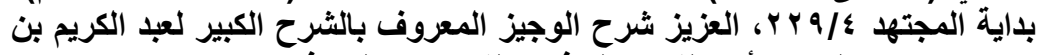

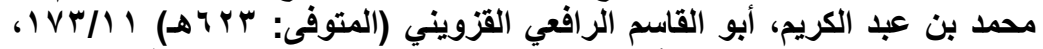

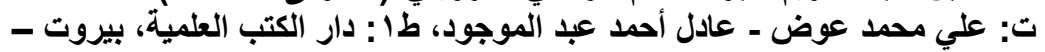

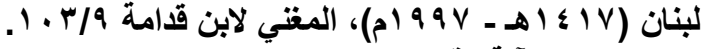

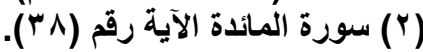

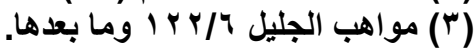

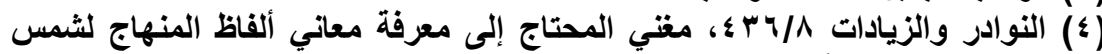

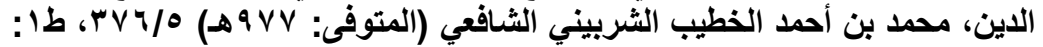

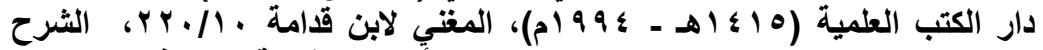

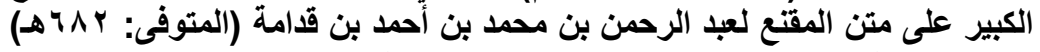

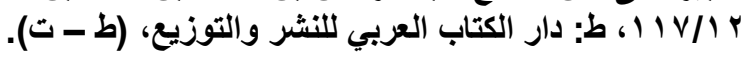


واستدلوا على ذلك بالأثر والمعقول:

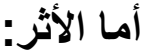

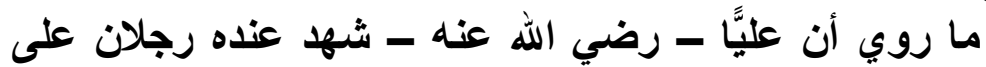

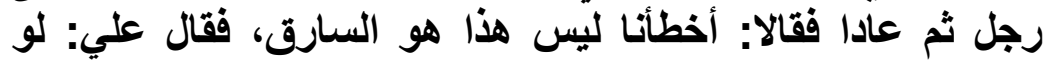

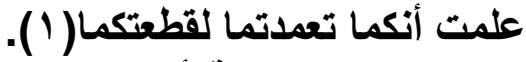

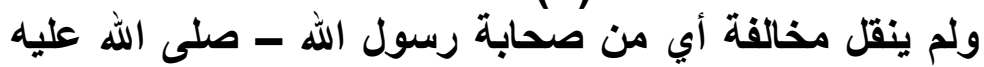
وسلم- لعلي وفي هذا يكون إجماعاً.

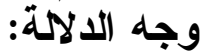

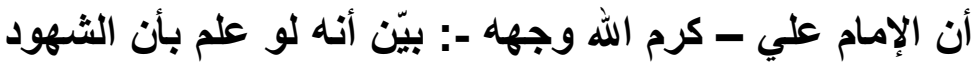

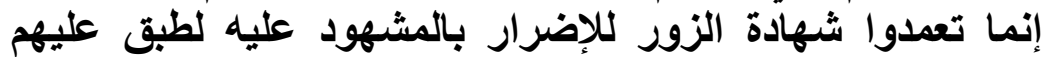

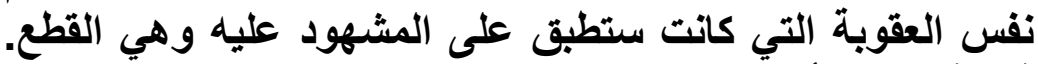

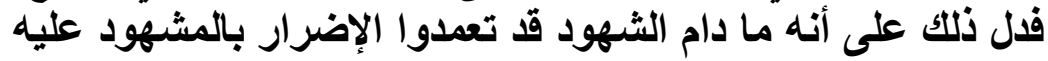
فإنهم ينالون نفس العقاب الأي يناله المشهود العهود عليه.

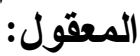

أن الشاهدين تسببا بشهادتهما زوراً عامدين إلى قتله أو قطعه

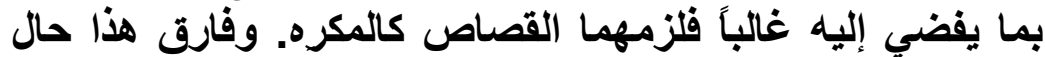

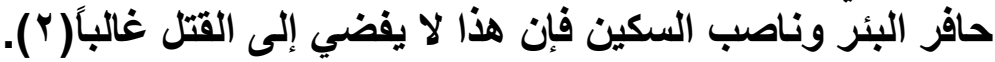
وهو قول الإمام أبو حنيفة حيث قال بعدم القود من الثاهدين

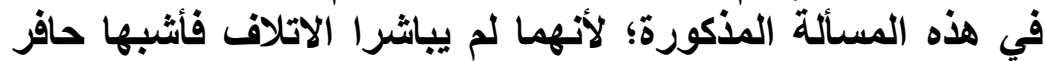

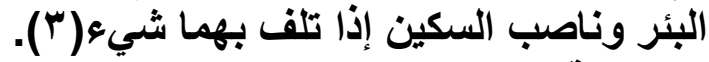

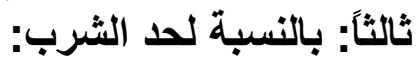

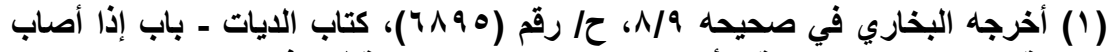

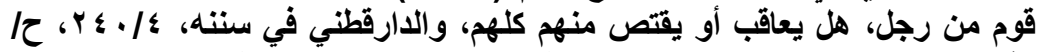

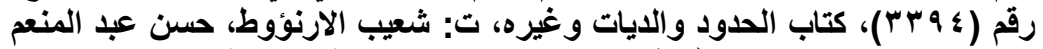
شلبي، عبد اللطيف حرز الله، أحمد برهوم، طأ : مؤسسة الرسالة، بيروت - لبنان

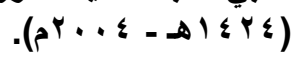

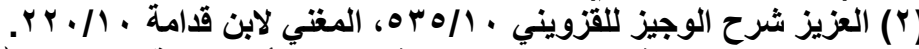

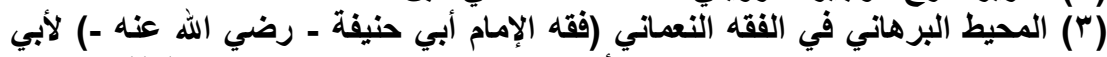

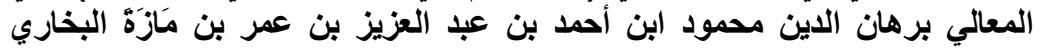

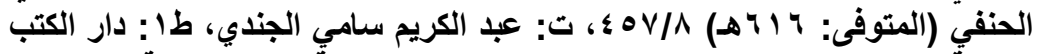

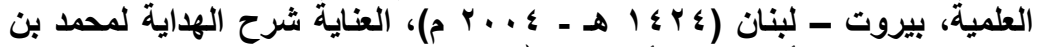

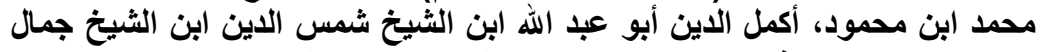

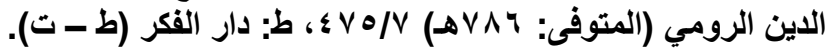


عرف بعض الفقهاء الشرب المحرم بقوله: شرب مسلم مكلف

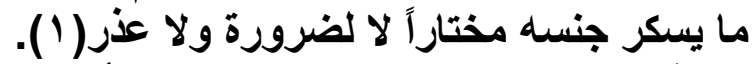

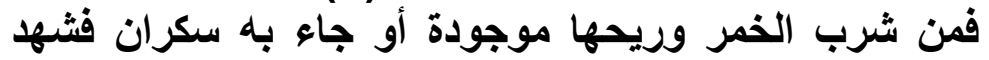

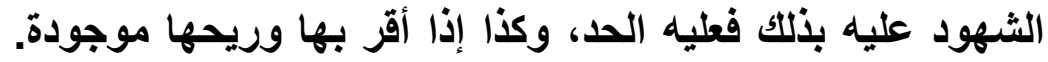

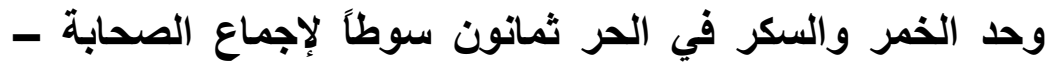

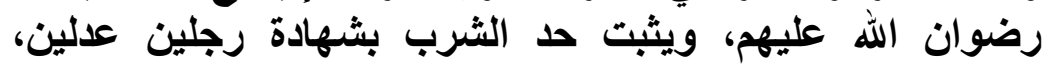
ويثَبت بالإقرار مرة واله واحدة.

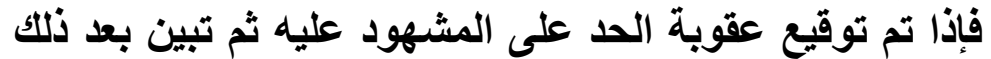

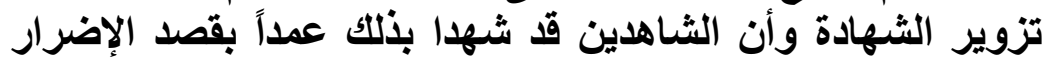

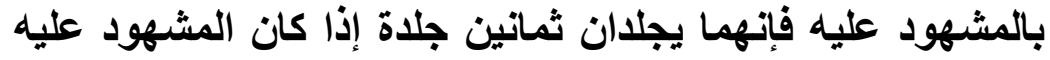

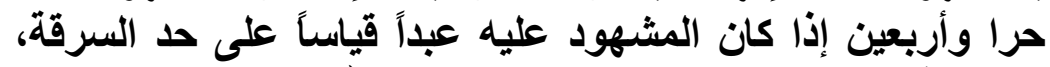

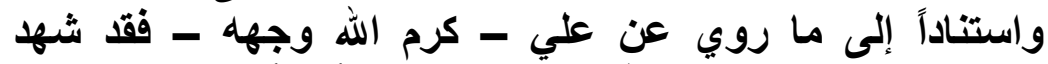

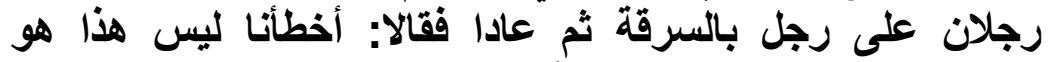

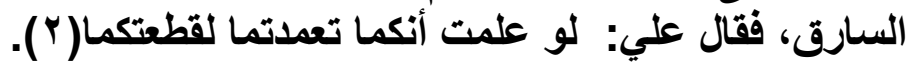

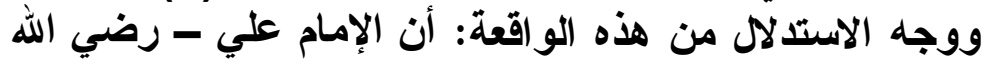

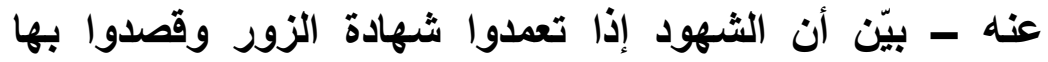

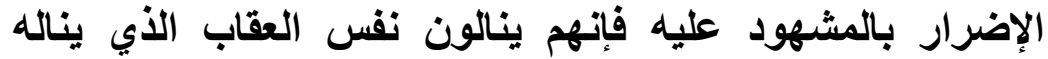

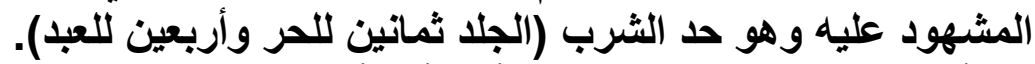

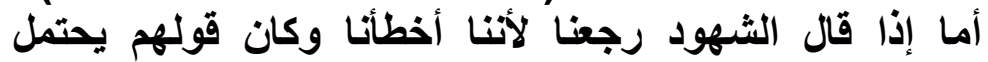

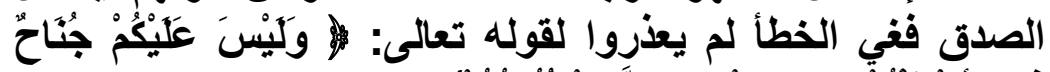

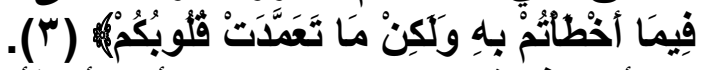

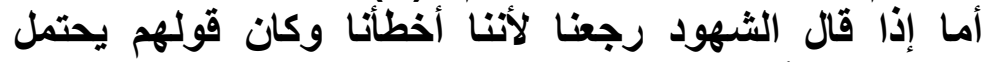

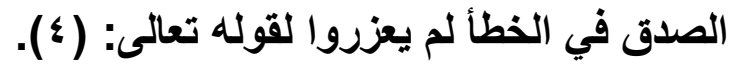

(1) الهداية الكافية الثافية لبيان حقائق الإمام ابن عرفة الوافية. (شرح حدود ابن عرفة

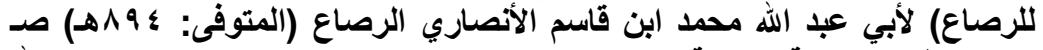

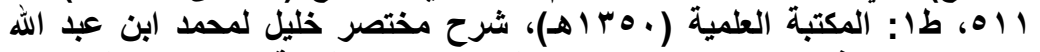

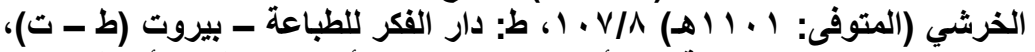

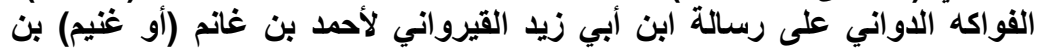

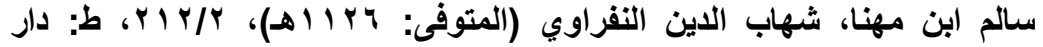

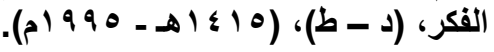

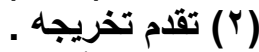

$$
\begin{aligned}
& \text { (؟) سورة الأحزاب من الآية رقم (0). }
\end{aligned}
$$

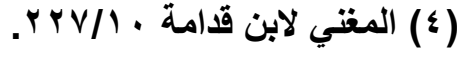


أما إذا كان الرجوع بعد تنفيذ الحكم فإنهم يضمنون الدية، فإذا

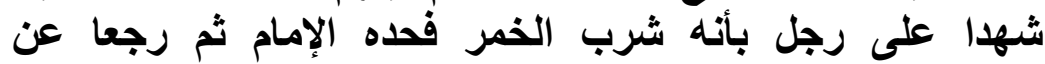

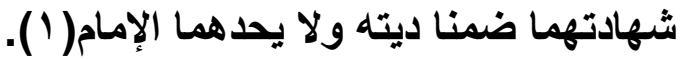

عرف بعض الفقهاء القذف بأنه: رمي مكلف ولو كافرا آدمياً

$$
\text { رابعاً: حـ القذف: }
$$

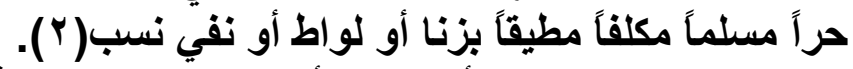

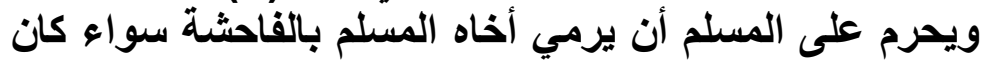
صادقاً عند نفسه في اتهامه أم كأن كاذباً. أما في حالة الكنب فإنه بهتان وظانيان وانلم، والكنب من أقبح المحرمات. وأما في حالة كونه صادقاً عند نفسه فلأنه كثف لنف للأسرار

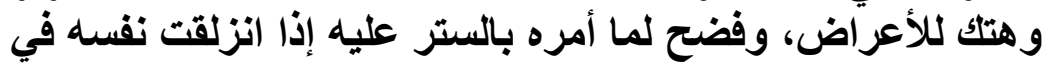

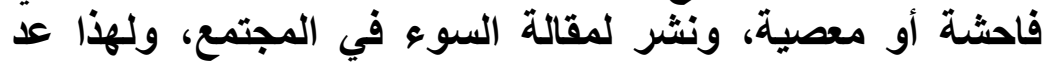

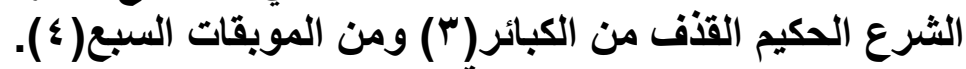
ويستال على تحريمه بالكتاب و السنة والإجماع:

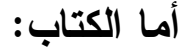

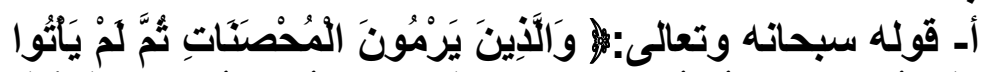

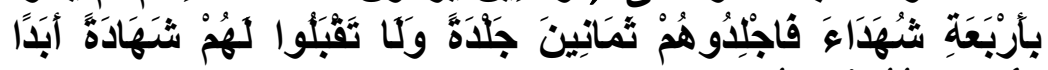

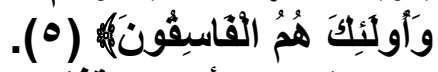

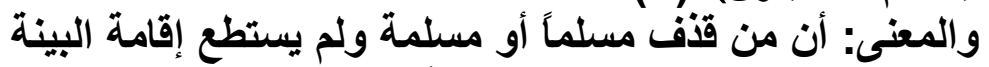
المطلوبة لإثبات قوله فهو كاذب عند الله وحكمه حكم الكاذب يقيناً.

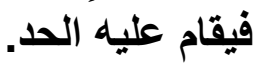

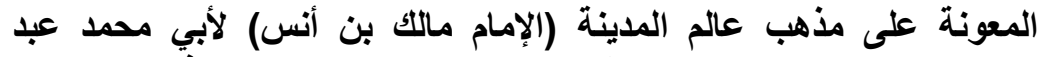

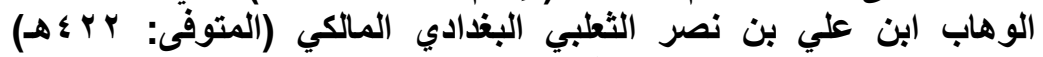

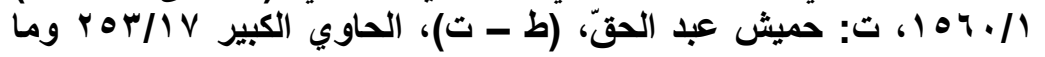

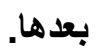

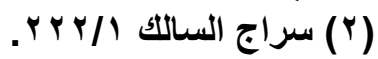

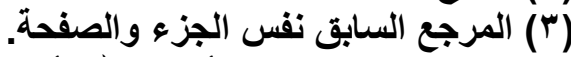

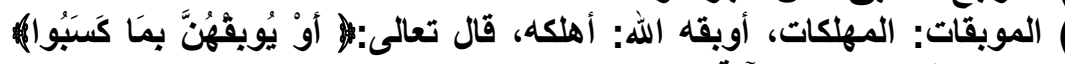

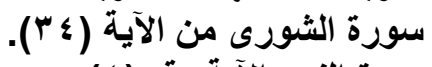

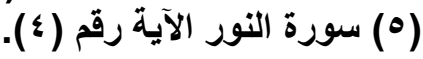




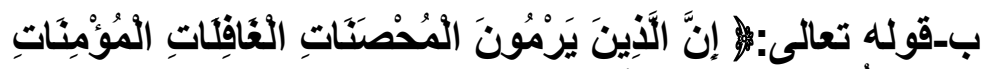

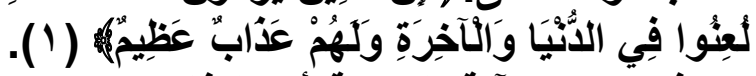

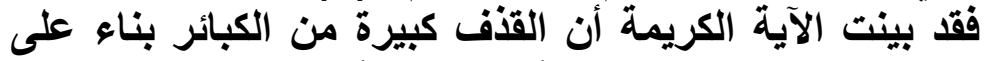

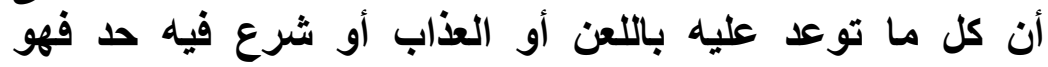

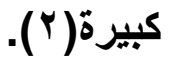

كما بينت الآية أيضاً أن الرامي للمؤمن والمؤمنة الحر بالزنا

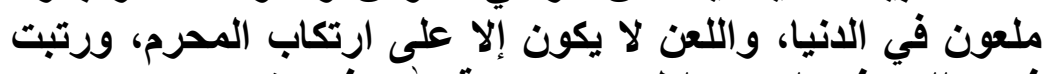

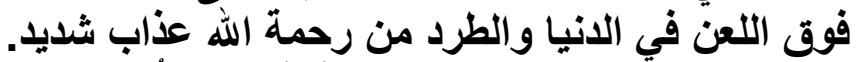

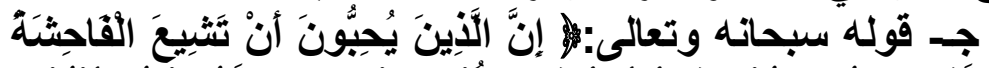

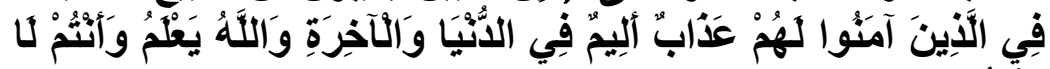

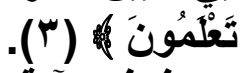
فهذه الآية بينت أن الذين يحبون إثاعة الفاحشة بأي شكل من

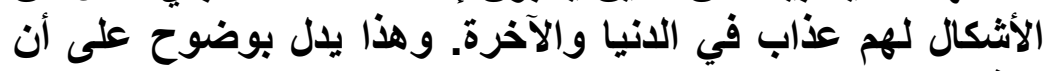
القذف حرام وكبيرة من الكباب في الائر.

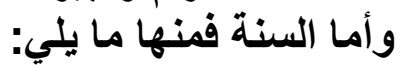

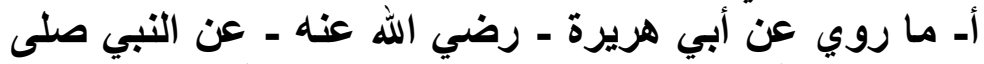

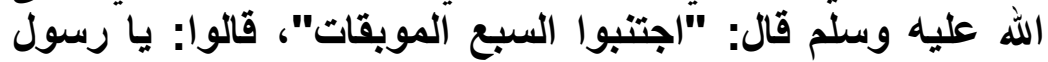

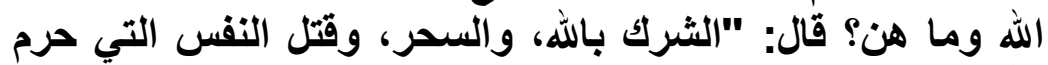

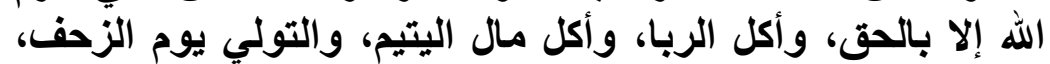

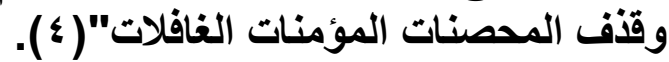
وجه الدلالة:

أن الرسول - صلى الله عليه وسلم - وضع قذّف المحصنات

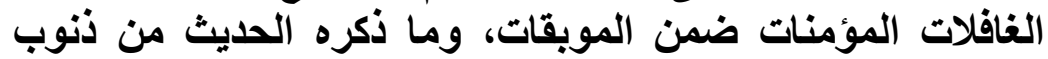
هي من أكبر الكبائر، فكان القذف في نظر الثرن الثرع من أكبر أكبر الكبائر.

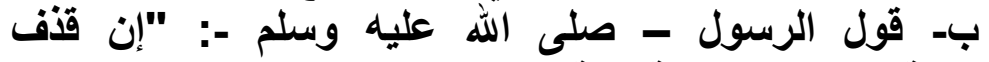
المحصنة ليهزم عمل مائة سنة" الرسول. 
فهذا الدايث يدل على أن القذف يحبط الأعمال كغيره من

$$
\text { الأنوب العظام (1). }
$$

جـ قول النبي ـ صلى الله عليه وسلم -: "من قنف ذميًّا حـ له

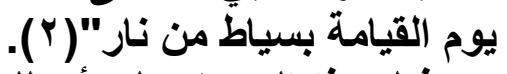

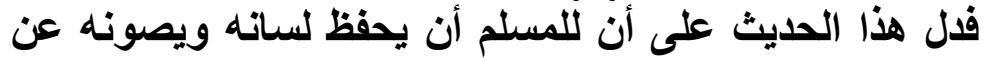

الذوض في أعراض الناس حتى مع غير المسلمين ألمان وإلا عرّض

نفسه للعقاب يوم القيامة.

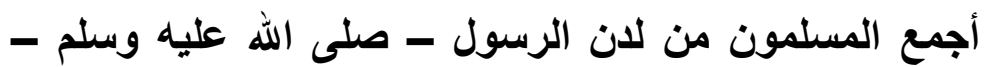

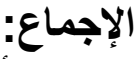

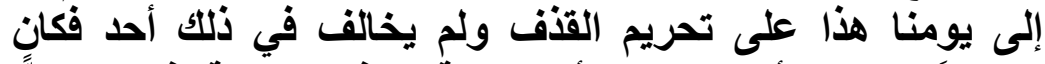

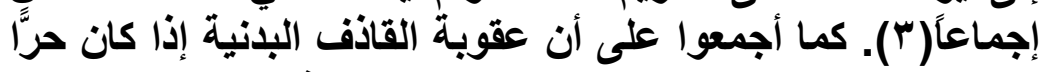

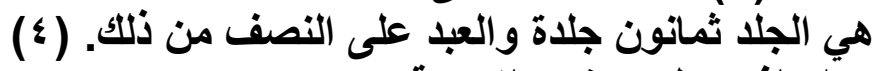

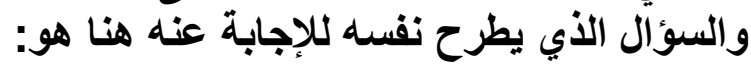

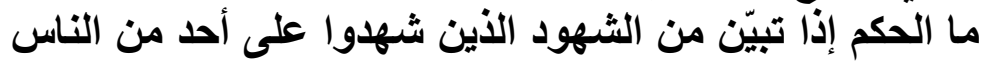
بالقذف أنهم قد زورّروا في شهادتهم عمداً لإلحاق الضرر بالثهاد الثهود

عليه؟

ولكلإجابة عن ذلكك نقول وبالله التوفيق:

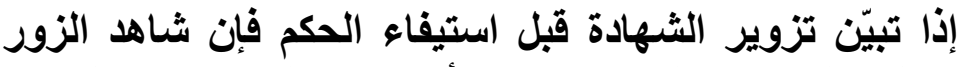

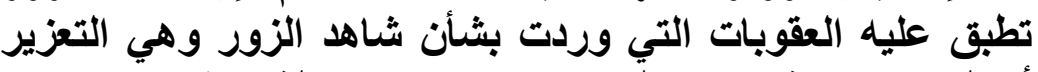
أو الضرب والإثهار به إلى جاتب حرماتها من الثهات الثهادة.

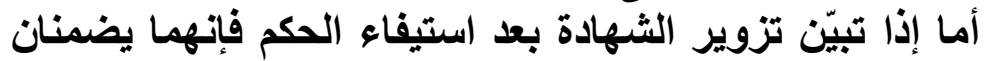

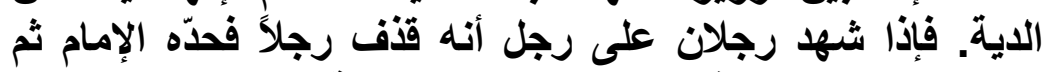

رجعا عن شهادتهما فإنها لا يضمنان إلا الدية وليس عليهما حـ.

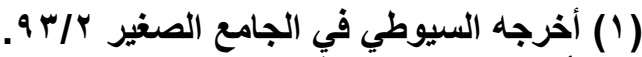

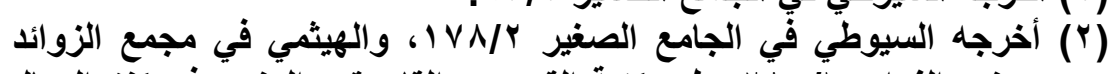

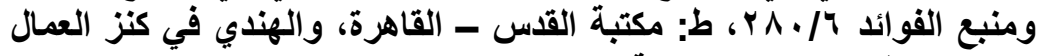

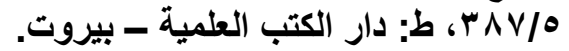

(r) الإجماع لابن المنذر صده ؛، كفاية الطالب الرباني بهامش حاشية العدوي

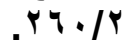

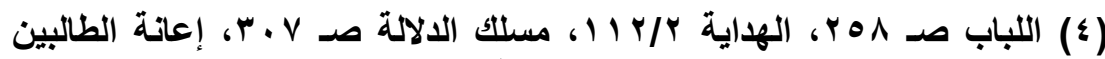

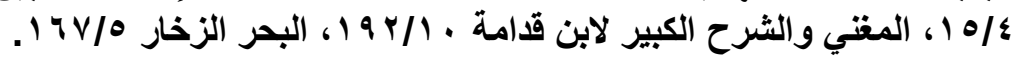




\section{المطلب الثانبي}

\section{الأنثر المتر تب على القصاص بشهمادة الزور}

إذا تبيّن تزوير الثهادة في الجرائم التي يترتب عليها الحكم

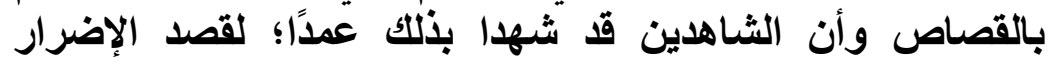

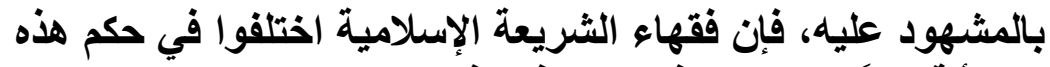

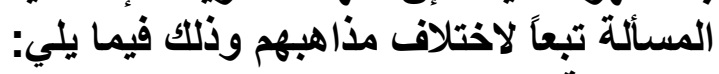

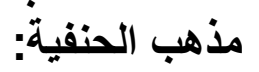

إذا رجع الشاهدان عن شهادتهما بالقتل قبل أن يقتص منه إنه

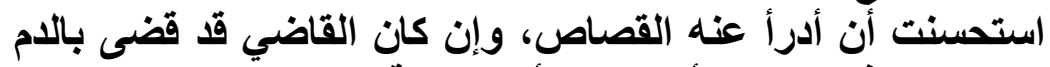

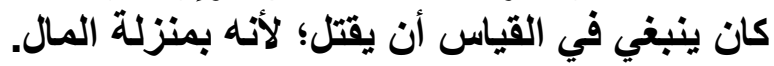

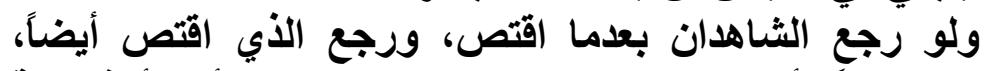

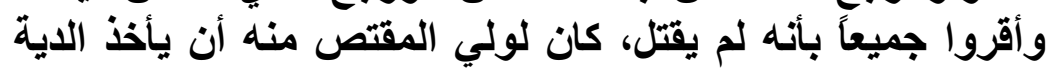

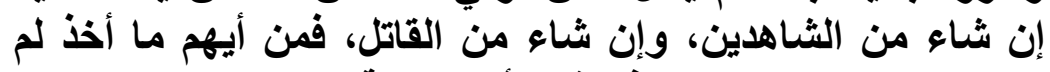

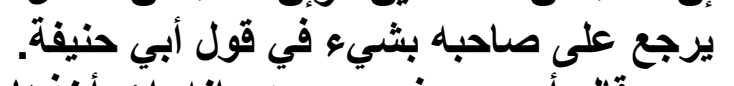

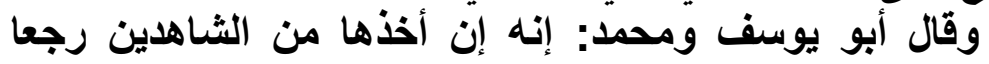

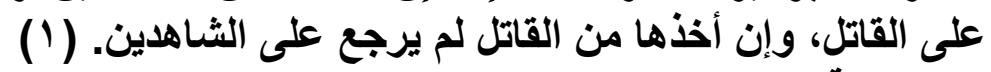

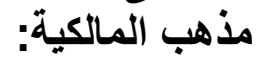

إذا رجع الشاهلان عن شهادانهما في الجرائم التي يترتب عليها

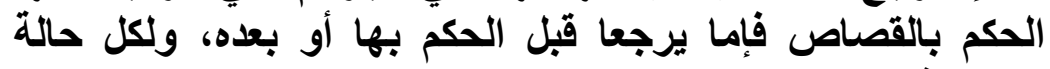
حكمها فيما يلي: الحياصن الرجوع قبل الحكم بالشهادة: فيمان:

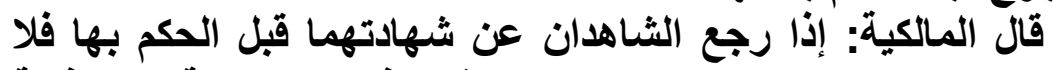

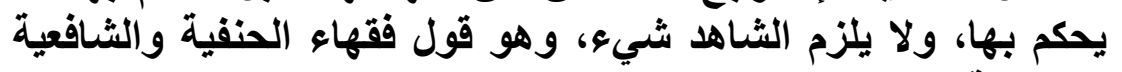

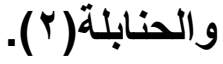

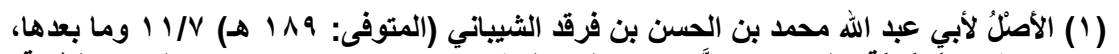

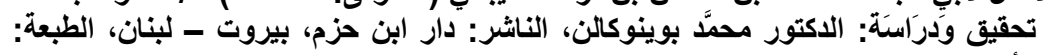

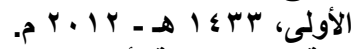

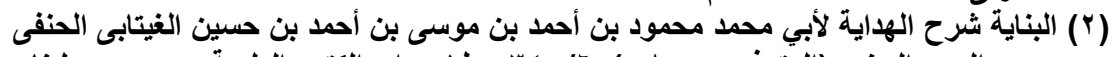

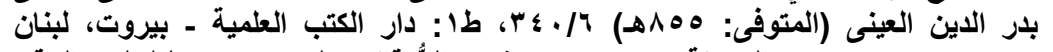

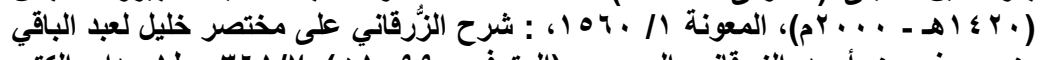

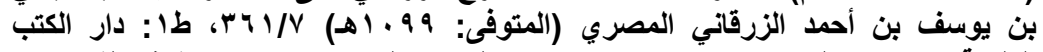

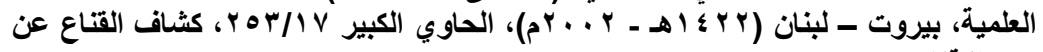

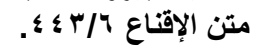




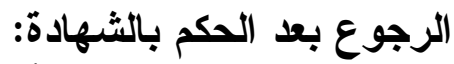

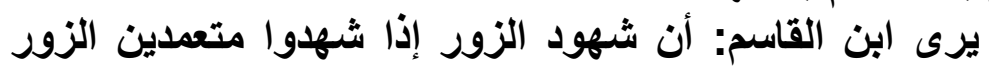
في شهادتهم يوجعان ضرباً ويطال سجنهما ويغرمان الدية في الزي وقال أثثهب: يغرم الثاهدان الدية إذا لم يتعمدا الزور، ويقتص

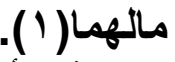
منهما إذا تعدا الزوري.

أما إذا رجع أحد الثهود عن شهاديادته بعد أن صدر الحكم

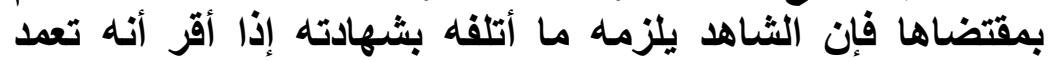
الزور، ثم إن شهادته التي رجع عنها بعد الحكم إن كانت في دم التهات

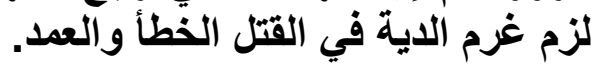

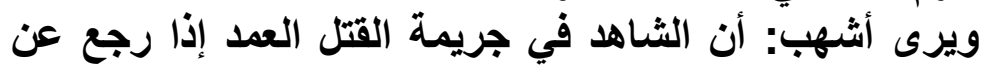

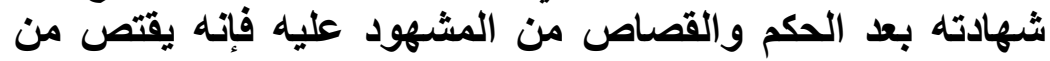

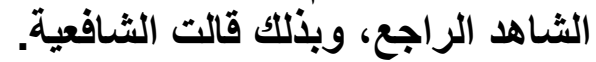
ويلاحظ: أنه إذا علم ولئ الثام كذب الثئه الثهود واقتص من المشهود عليه فإنه يقتص منه. آنها وقال المالكية: لا غرم على الثهود إذا شهدوا على على ولي الام بأنه

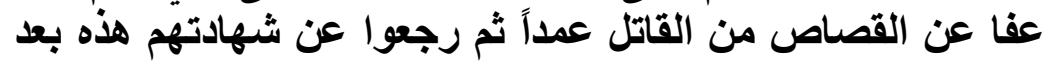

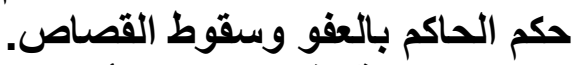

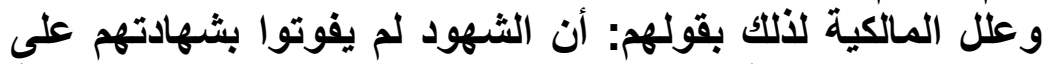

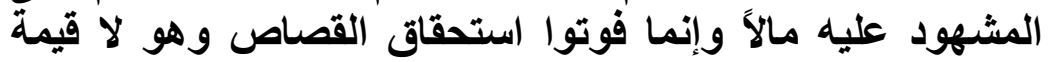

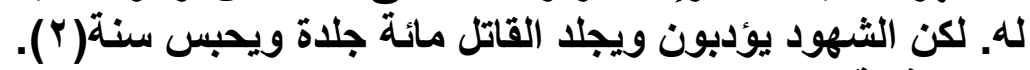

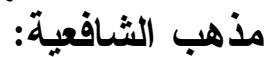

قتّم الثافعية حالات الرجوع عن الثهادة في الجرائم التي يترتب عليها الحكم بالقصاص الثات الى ثلاث حالات:

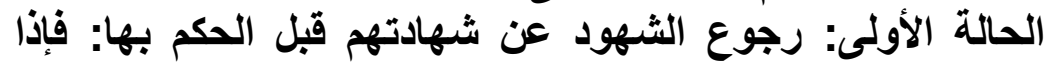
رجع الثهود عن شهادتهم قبل الحكم امتنع الحكم بها وإن أعادو العها؛

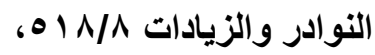

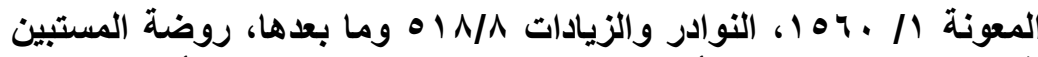

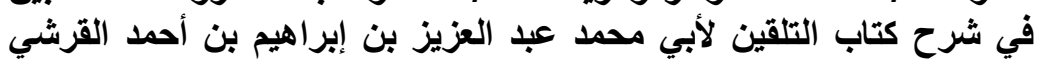

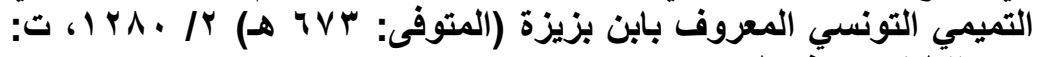

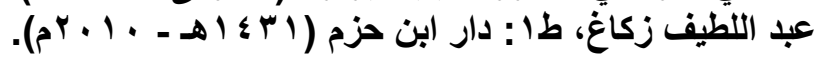


لأنه لا يدري أصدقها في الأول أم في الثاني، فلا يبقى ظن الصدق فيها.

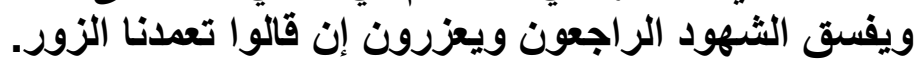

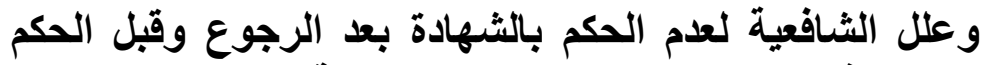

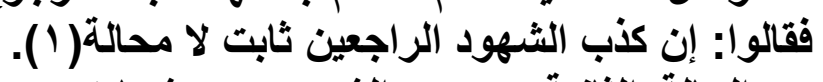

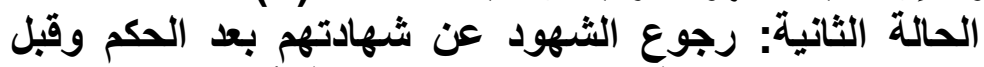

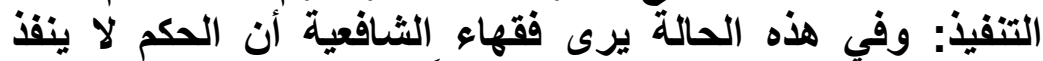

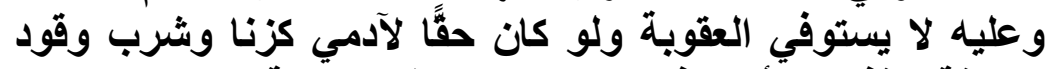
وسرقة وقفف؛ لأن هذه عقوبات تسقط بالثبهة، والثة والرجوع عن الشهادة شبهة.

الحالة الثالثة: رجوع الثهود عن شهادتهم بعد الحكم وبعد

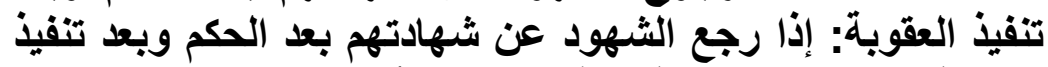

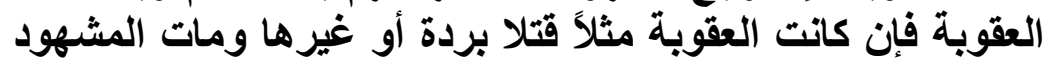

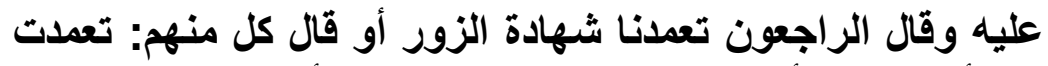
ولا أعلم حال أصحابي لزمهم القود بشرط الزمال أن يجهل ولي الدام

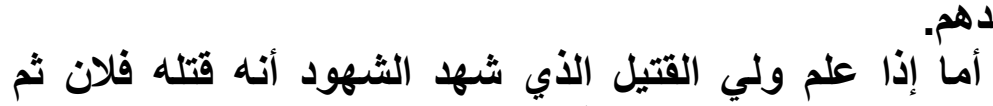

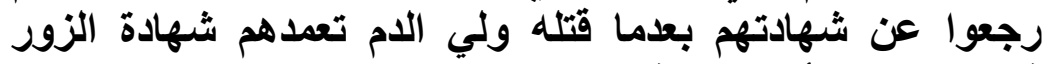

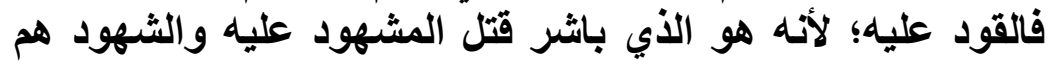

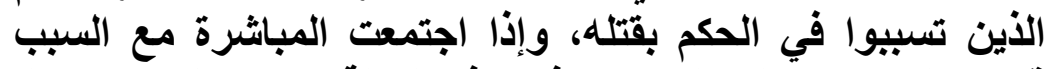

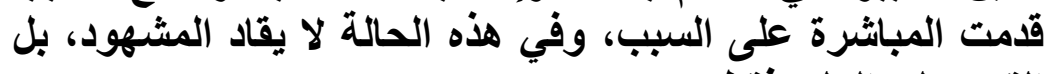
القود على الولي فقط.

وإذا آل الأمر في حالة علم الثي الولي بتعمد الثهود أن يشهاوا زوراً أو جهله إلى الآية فتجب الآية مغلظة وفي مالهمه.

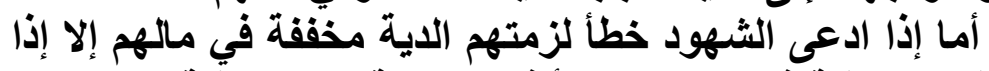

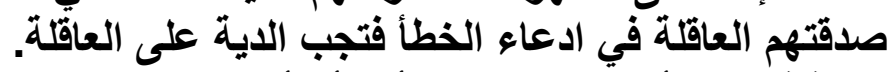

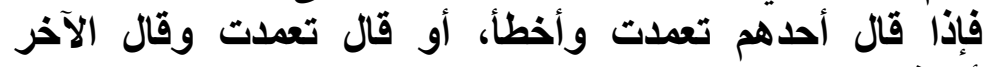
أخطأت فالقود على المتعد. وإذا آل الأمر إلى الدية فعلى المتعدد قسط من دية مغلظة، و على المخطئ قسط من الاية مخففة (1).

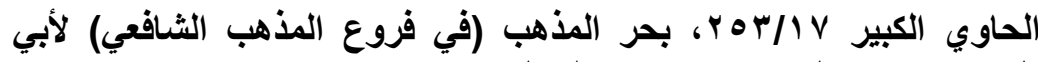

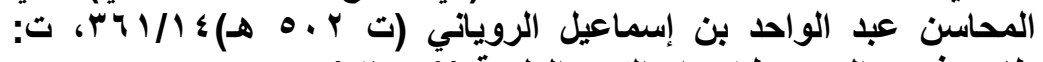

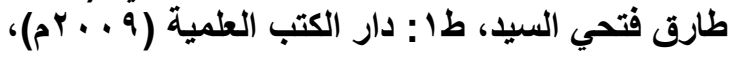




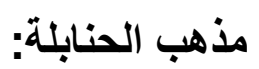

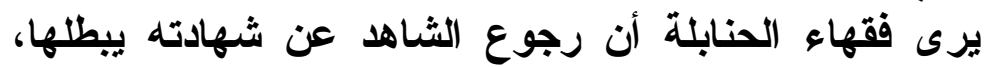

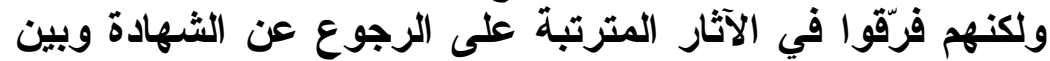

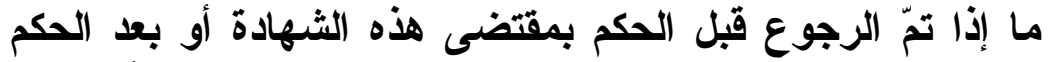

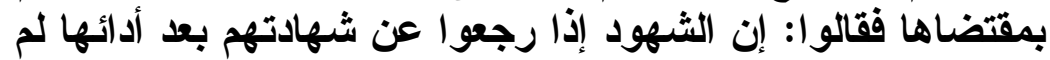
يخل الحال من واحد من أمور ثُلاثنة:

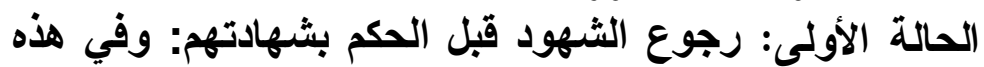

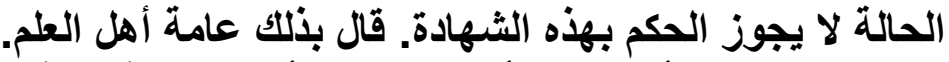

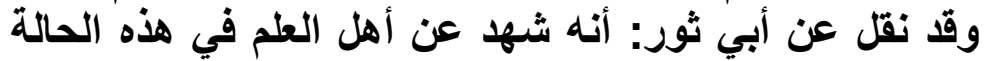

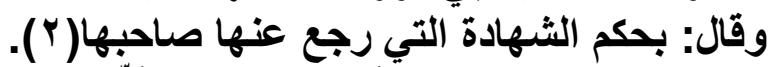

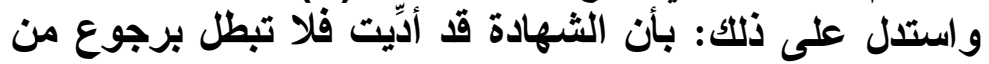

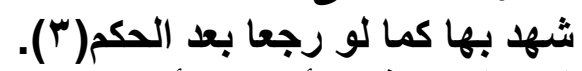
وقد نوقش هذا الرأي بما يأتي:

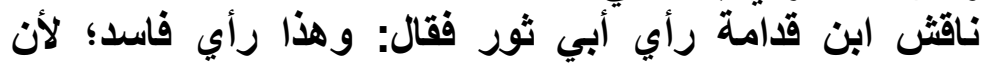

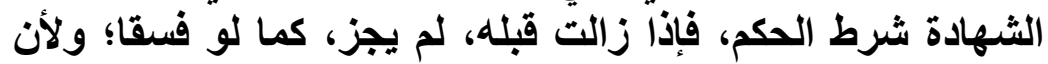

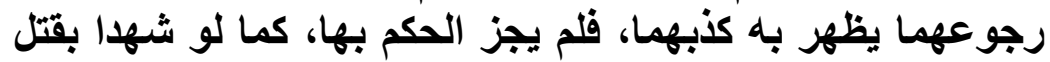

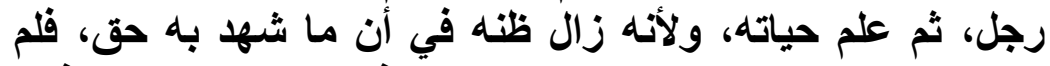

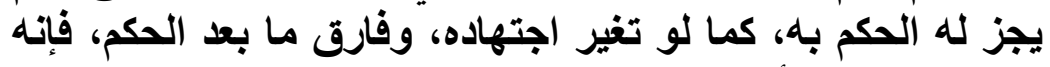

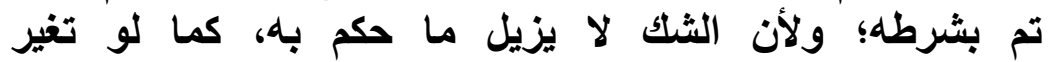

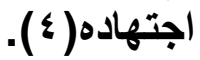
الحالة الثانية: رجوع الشهود بعد الحكم وقبل الاستيفاء:

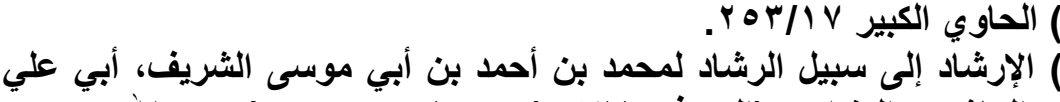

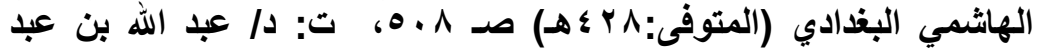

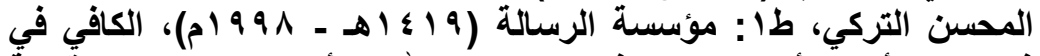

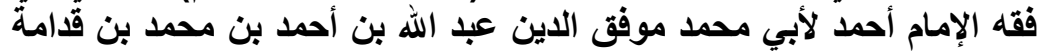

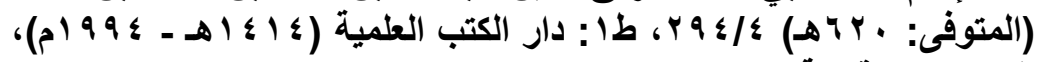

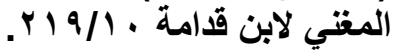

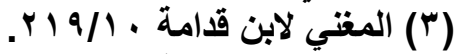

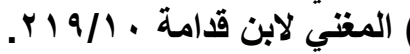


إذا رجع الثاهدان بعد الحكم بثهادتهما لكن قبل الاستيفاء

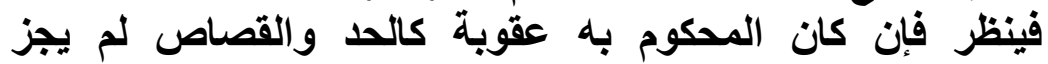

الحالة الثالثة: رجوع الثهود بعد استيفاع الحكم:

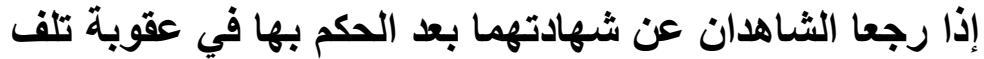

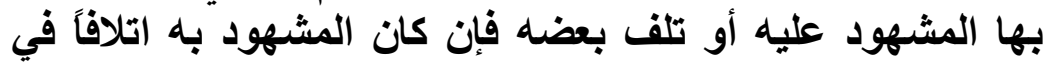

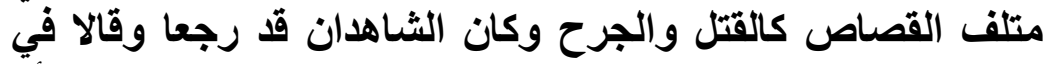

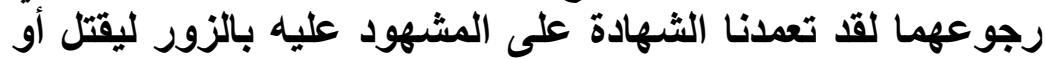

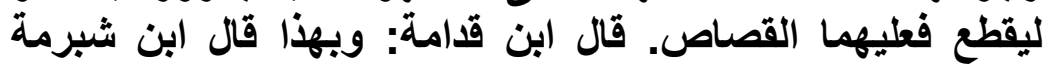

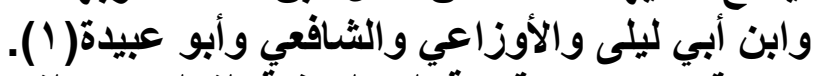

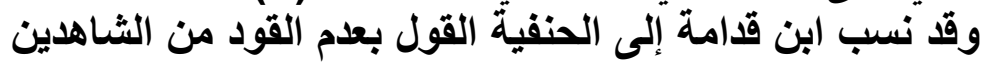
في المسألة المذكورة لأنهما لم يباشُرا الاتلاف فأنشبها حافر البئر

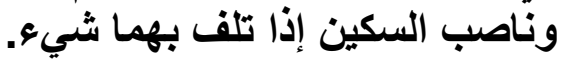
أما إذا لم يتعدد الثهود اتلاف المشئ المشهود عليه بأن بأن قال

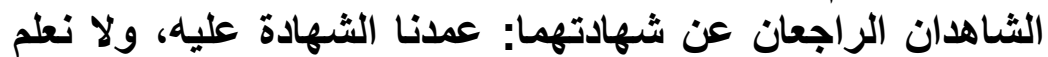
أنه يقتل بهذا. وكانا ممن يجوز أن يجهلا ذلكت، وجبت الدية في

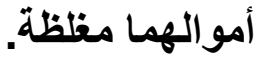
وعلل الحنابلة لرأيهم المذكور بقولهم: إن ما حدث بالثهادة

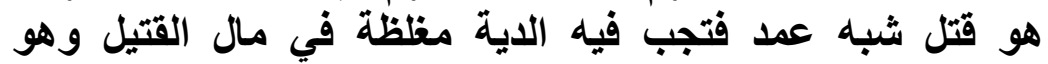

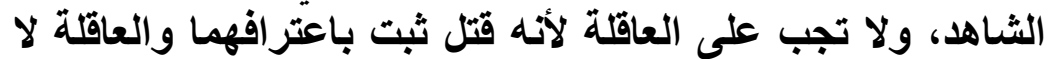
أما لو قال أحد الثاهدين عمدت قتلهاله. وقال الآخر: أخطأت.

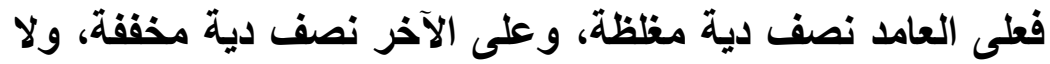

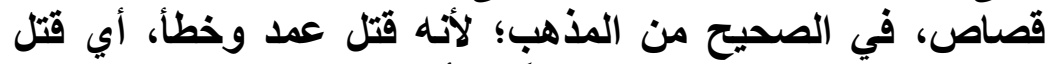
يسمى بثبه العمد كما يسمى عمداً خطأ.

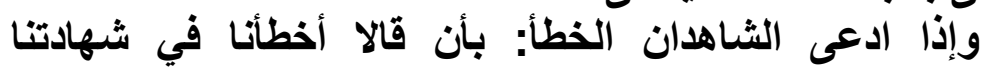
فعليهما الاية في أموالهما؛ لأن العاقلة لا تحمل الاعترافت(ب). 


\section{المطلب الثالث}

\section{الأثر المترتب على شمادة الزور في الأهوال المدنية}

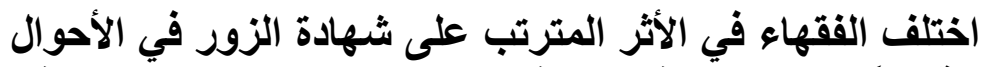

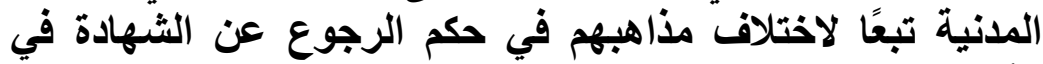

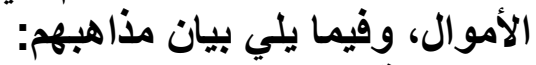

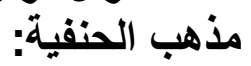

قالوا شهـا ببيع بأقلّ من قيمته ثم رجعا ضمنا قيمته.

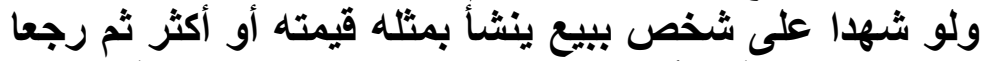

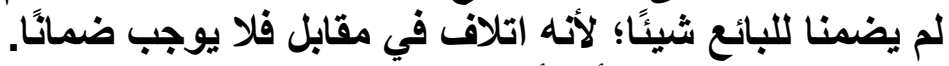

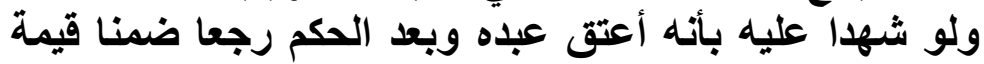

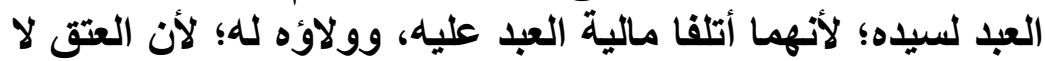
يتحول إليهما بهذا الضمان، فلا يتحول الولاء لاء إليهما.

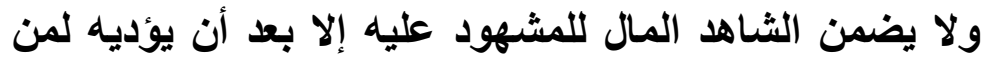

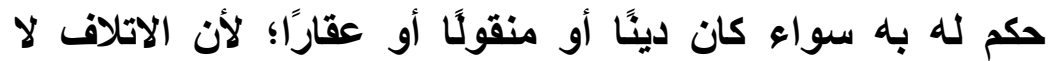

يتحقى إلا بعد التأدية فوجب أن يكون الضمان كنلك. (1)

قالوا: إن الرجوع عن الثهادة بعد الحكم بمقتضاه لا ينقض له اله

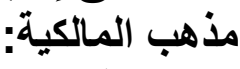

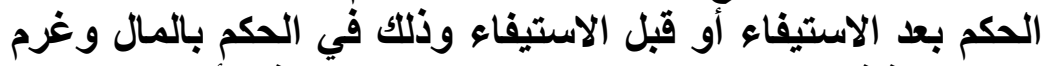

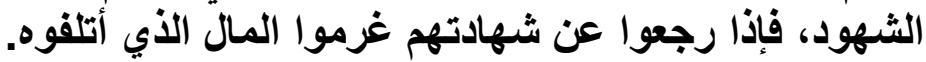
ويكون دفع الثهود الراجعون المال الذي أتلفوه إلى الثى المشهود الثهاد

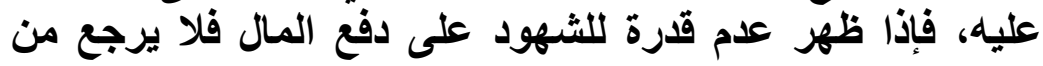

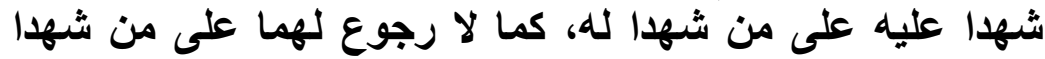

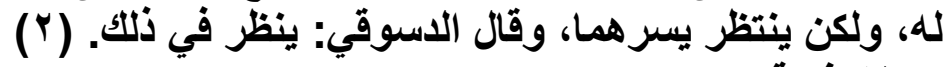

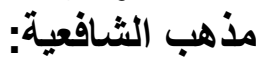

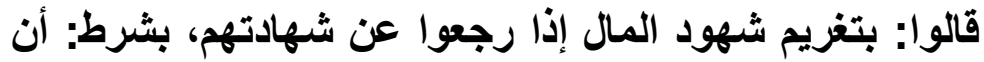

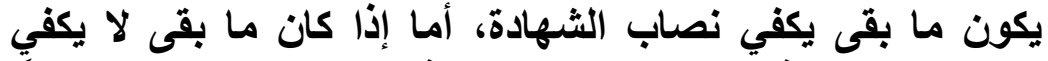

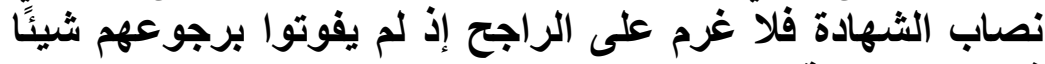
فقد بقيت الحجة بمن بقى. فئم

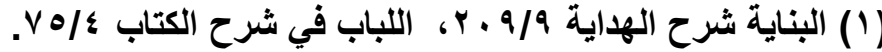

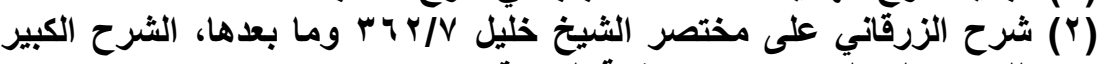

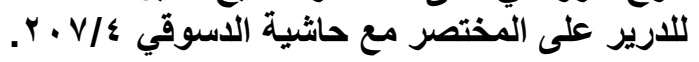


ويقسم الغرم على الثهود الراجعين بالسوية بينهم عند اتحاد

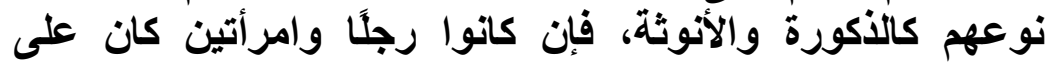

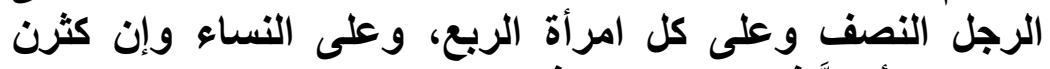

النصف؛ لأنهنَّ فيه كرجل، و هكذا. (1)

قالوا: إذا رجع شهود الإثبات بعد الحكم عن شهادتهم وكان إنان

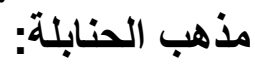

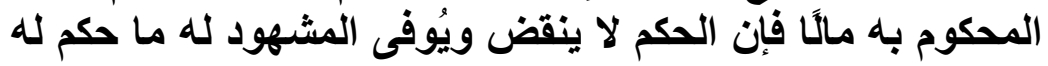

و وعللوا ذلك بقولهز: إن حق المشهود له وجب له فلا يسقط

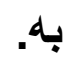

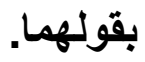

ويحقق هذا: إن حق الإنسان لا يزول إلا بيينة أو إقرار

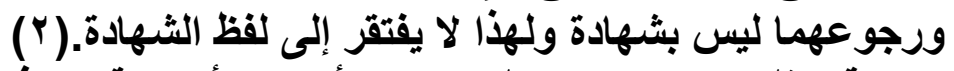

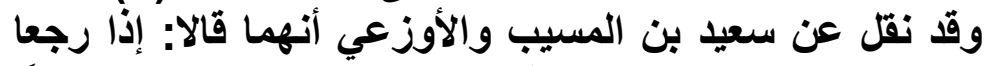

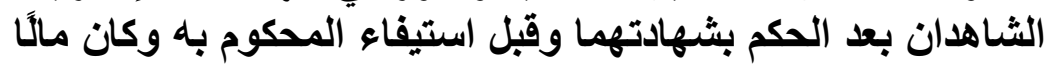

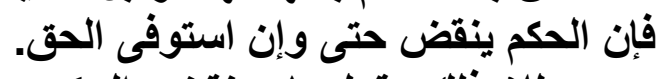

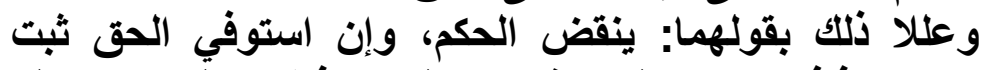

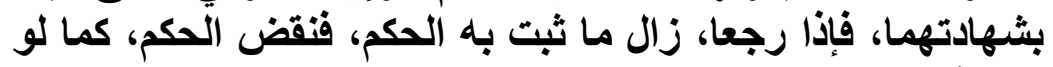

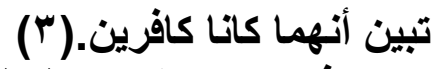

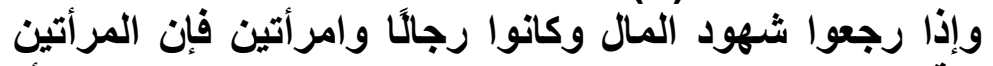

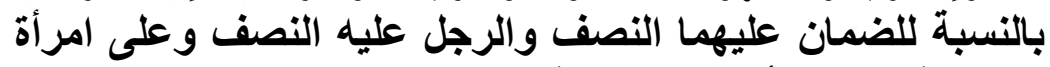

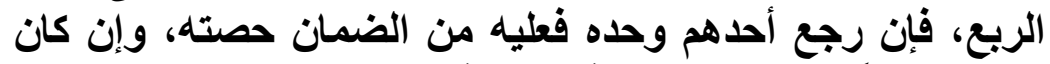

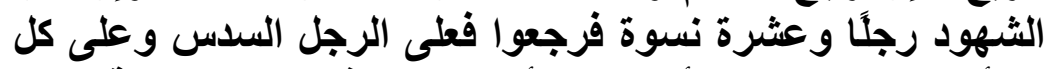

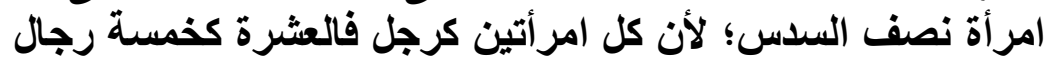
وبهذا قال أبو حنيفة والثافعي.

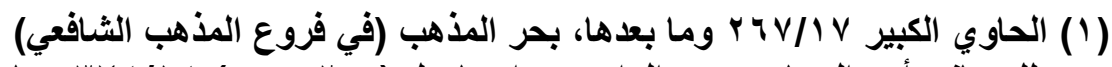

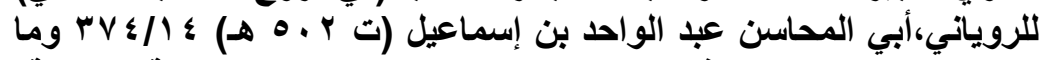

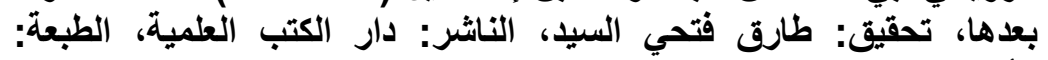

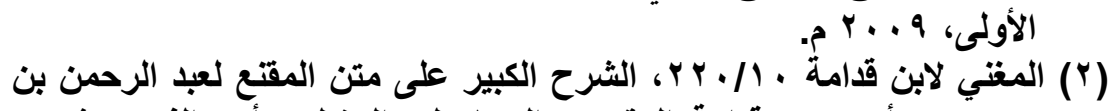

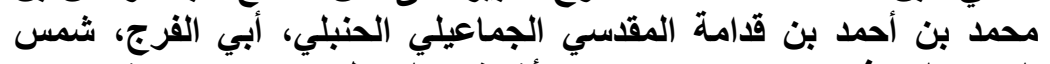

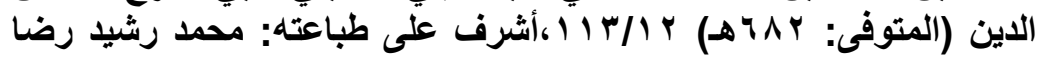

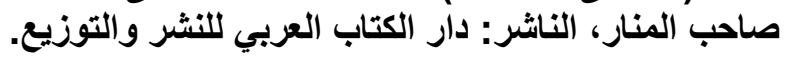

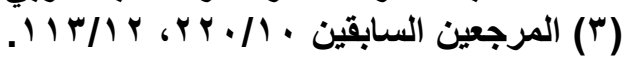


وإذا حكم الحاكم بثاهلا ويمين فرجع الثـاهلا غرم جميع المال؛

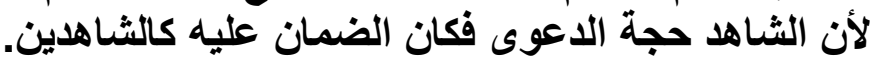

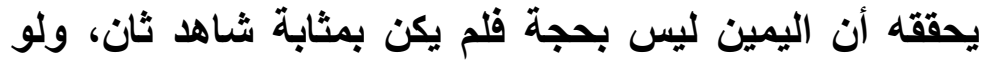

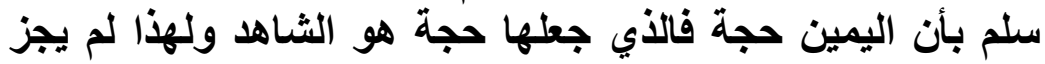
تقديمها على شهادته بخلاف شهادة الثاهد الثاني.

\section{المطلب الرابـ \\ الأثر المترتب على شهادة الزور في الأحوال الشخصية}

تتمثل مسائل الأحوال الثخصية في الزواج و الطلاق وما يترتب

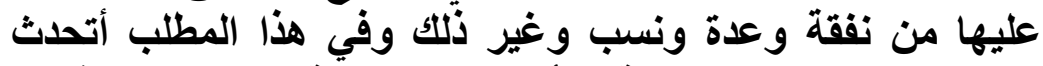

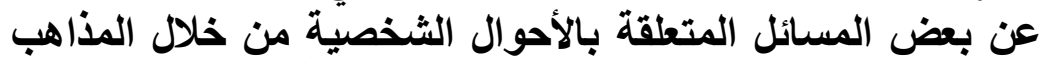
الفقهية لبيان حكم شهادة الزور فيها فأقول وبالله التوفيق:

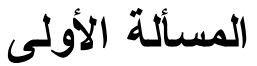

لو شها على رجل بأنه طلق زوجته ثُلائا بعد الاخول وحكم

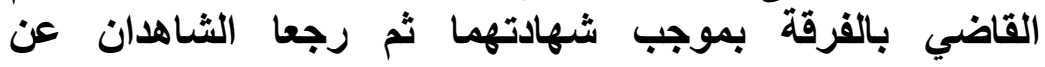
ذهب الحنفية: إلى أنهما لا يصدقان على إبطال الطلاق، ولا

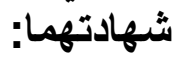
ضمان للزوج على الثناهاين. أما كونهما لا يصدقان على إبطال الطلاق، فنلتك لوجوه:

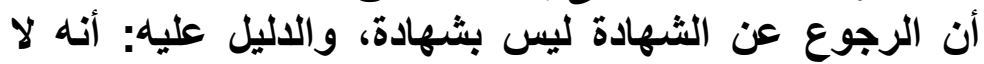

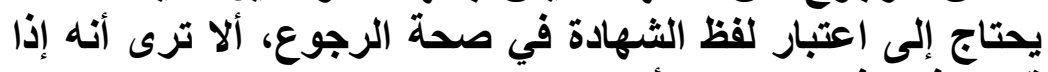

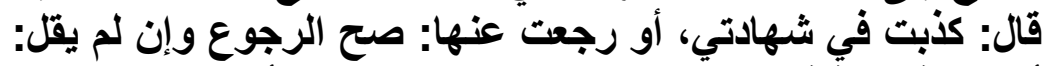
أثهال بذلك، فُإذا لم يكن الرجوع شهادة، لم يجز أن يفسخ به حكم

أنه مكذب نفسه في الرجوع عن الثهادة الأولى، فلا يثبت حكم

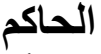

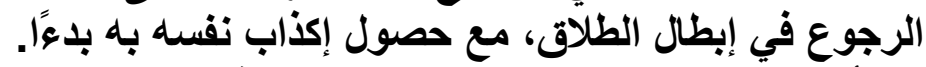

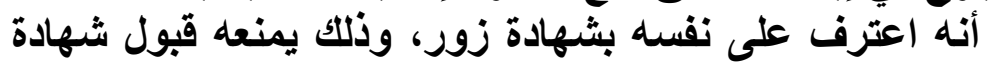
أخرى منه لو شهذ بها، كذلك يمنع تصديقه على إبطال حق الغير برجوعه. 


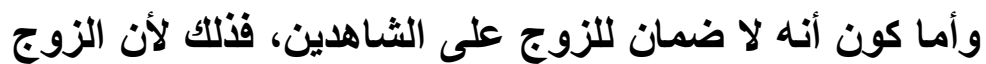

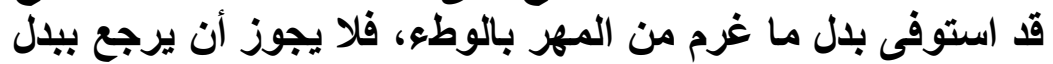

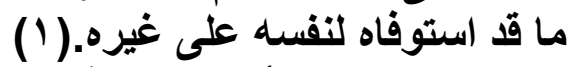

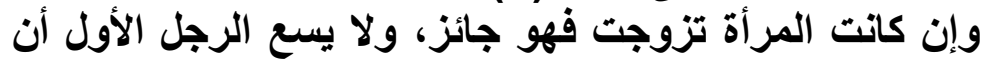

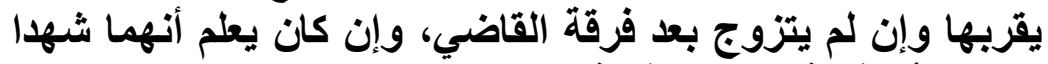

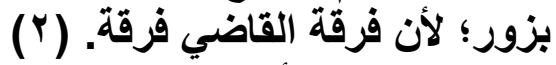
ولو تزوجها أحد الشَاهدين؛ حل له وطؤها، ورئ وإن كان يعلم أنهما

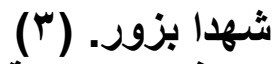
ذهب المالكية والحنابلة: إلى أنه لا شيء على الثئ الثاهاين، ولكن

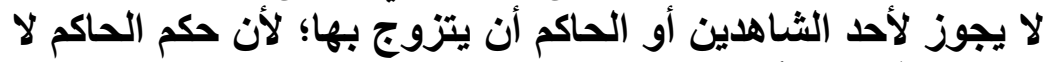

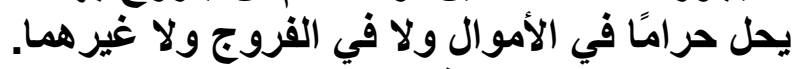

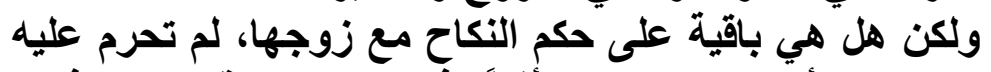

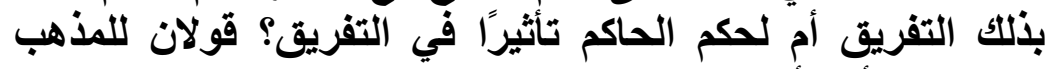

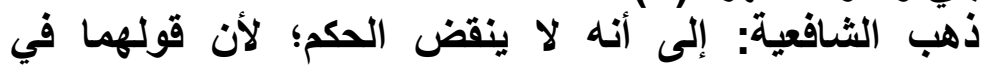

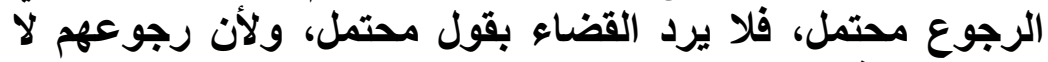
يقبل بالنسبة له، لكن يجب الغزم على الثاهدين، وهو مهر المثل؛

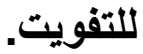
ومحل رجوع الزوج عليهم بشروط: 1. 1. أن لا يصدقهم. r. أن لأكون شهُهادتهم على حي وإلا فلا غرم عليهم.

(1) شرح مختصر الطحاوي لأحمد بن علي أبو بكر الرازي الجصاص الحنفي

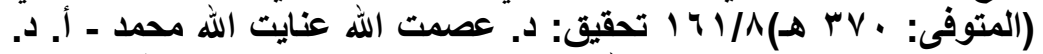

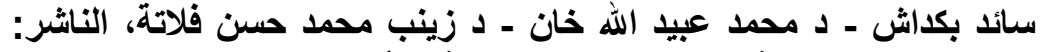

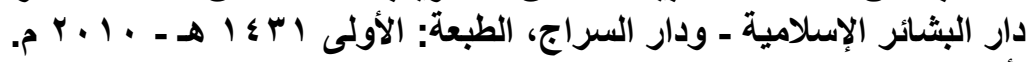

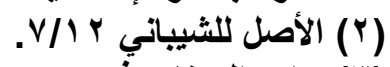

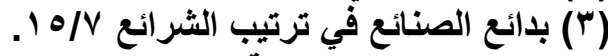

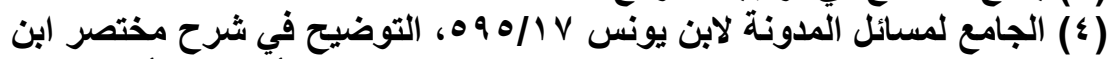

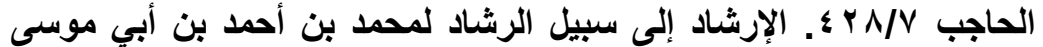

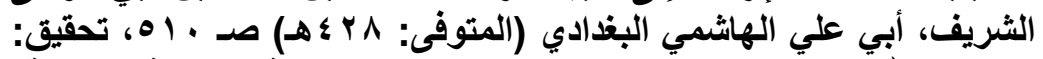

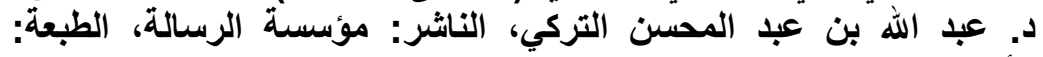

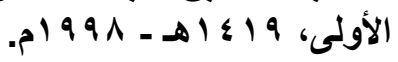




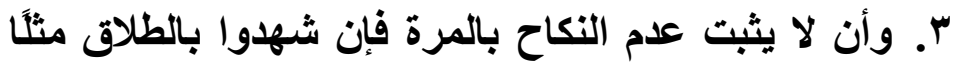

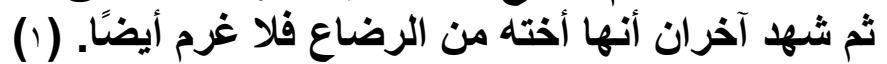

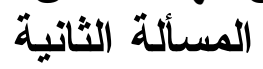

لو شهـا على رجل بأنه طلق زوجته قبل الاخول، وبعد الحكم

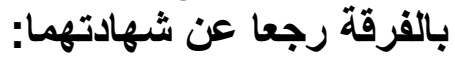

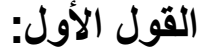

ذهب الحنفية، والمالكية في قول، والثافعية في قول، الثقال

والحنابلة: إلى أن الثناهدين يضمنا للزوج في فصف المهر.

وذلك لوجهين:

أحدهما: أن الطلاق قبل الاخول يسقط المهر كله، كهلاك المبيع المباف

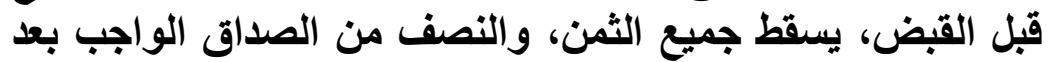

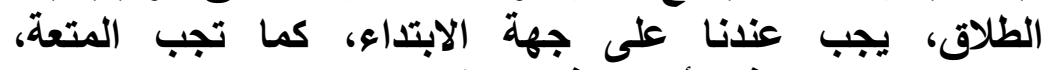

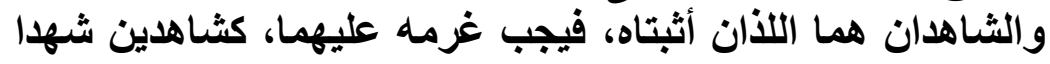

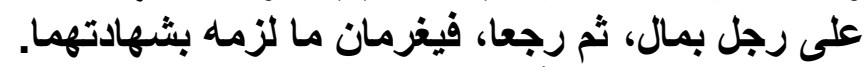

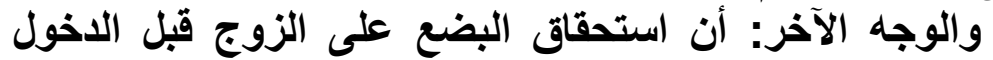

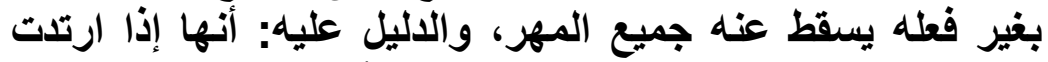

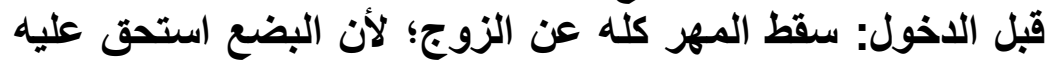

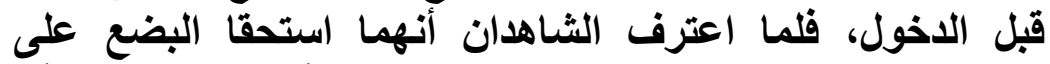

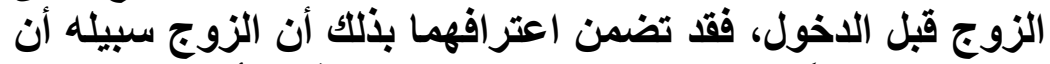

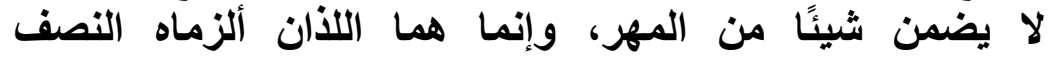

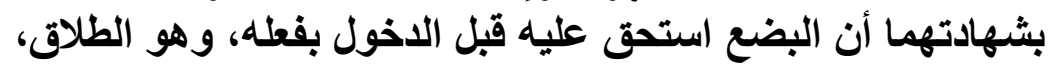

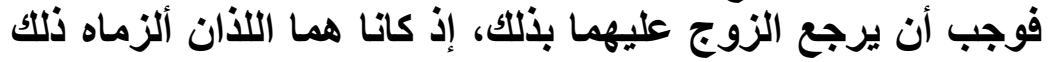

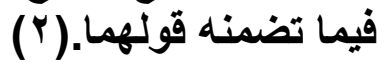

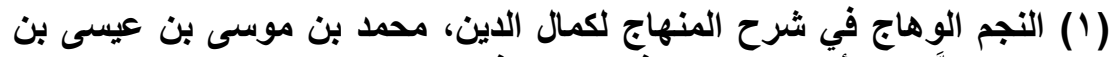

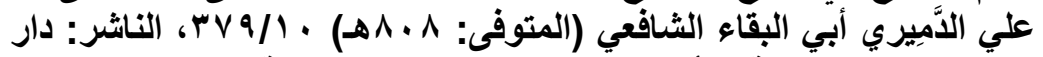

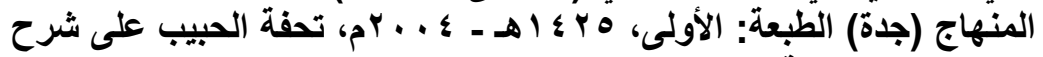

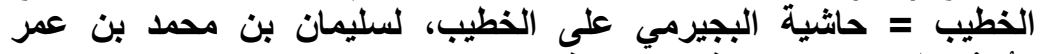

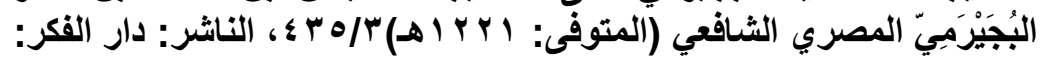

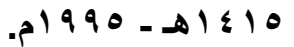

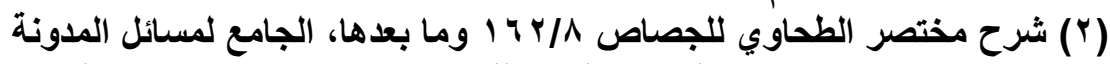

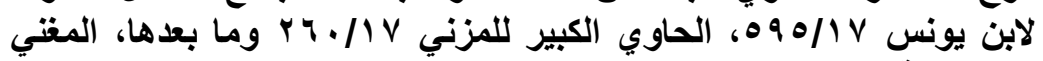

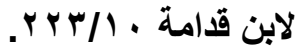




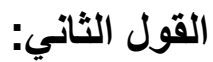

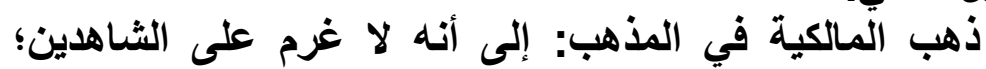

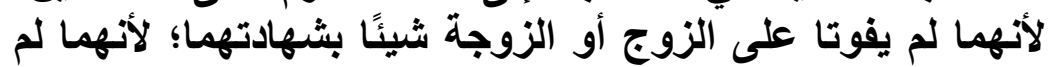

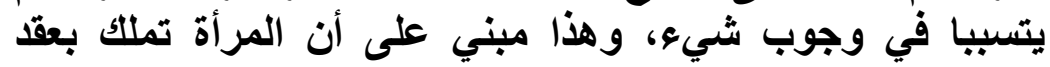

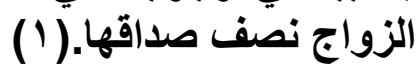

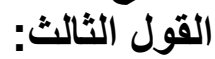

ذهب الثافعية في قول آخر: إلى أن الشاهدين يضمنا مهر

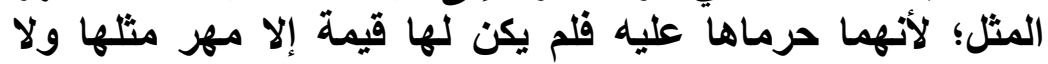

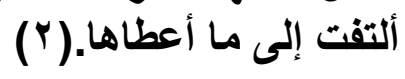

\section{المطلب الفامسر

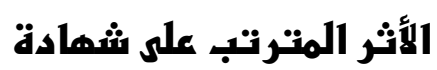

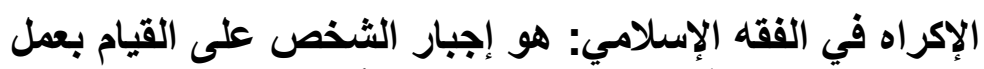

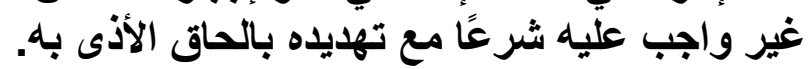

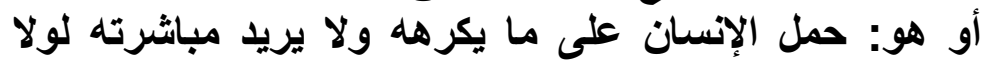
الحمل بالو عيد. والاكراه في شهادة الزور بعد إكراهًا بغير حق؛ ولذلك فإن

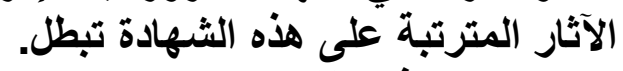

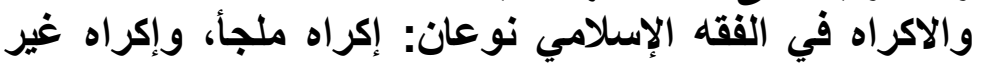

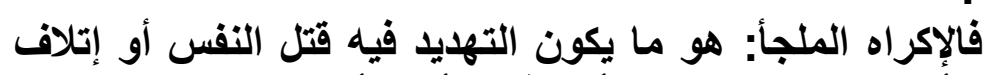

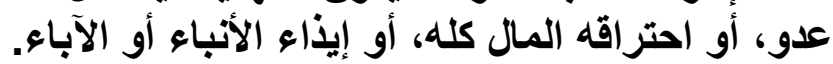

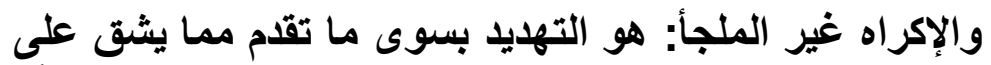

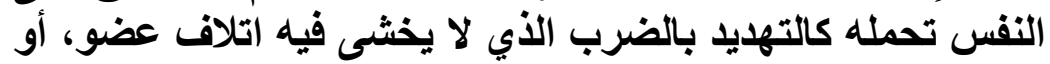
إتلاف بعض المال. والإكراه بنوعيه لا يؤثر في الأهلية بل المكره مع هذا الإكراه

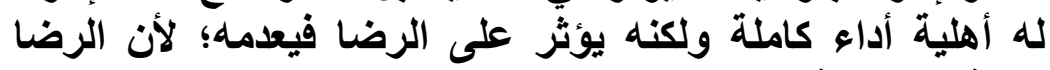

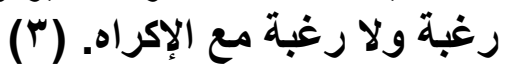

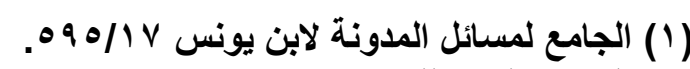

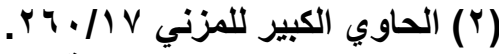

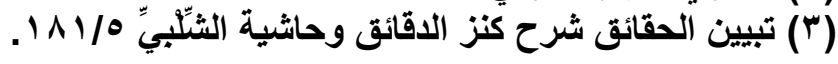

$$
\begin{aligned}
& -I V \varepsilon=
\end{aligned}
$$


والسؤال الذي يطرح نفسه هنا هو الأثر المترتب على الإكراه في وللإجابة على ذلك أقول وبالله التوفيق:-

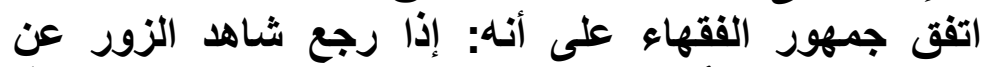

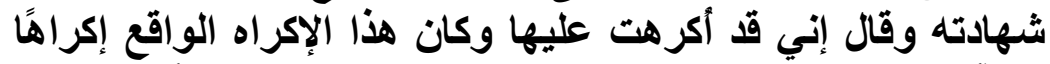

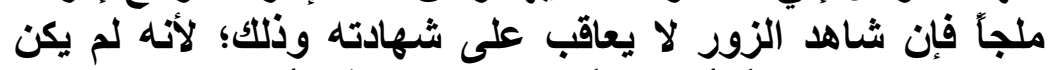

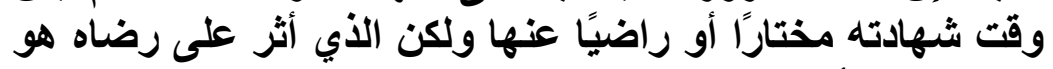
الإكراه الملجأ الواقع عليه.

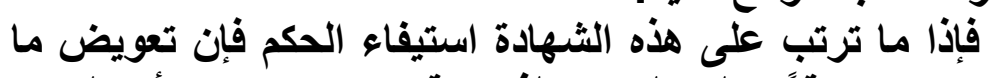

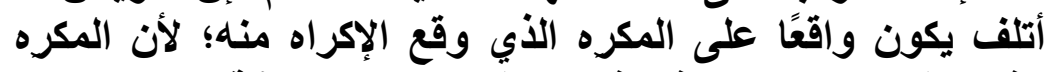

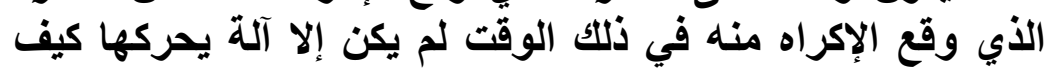
(1) يشاءي وفع الأر وذهب فقهاء الحنفية إلى القول: بأن المكرَه مؤاخذ بأقو الده(؟).

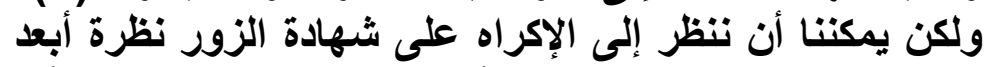

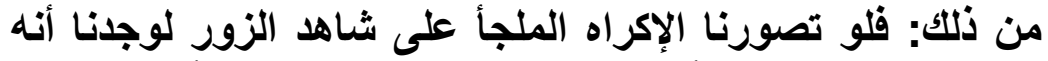

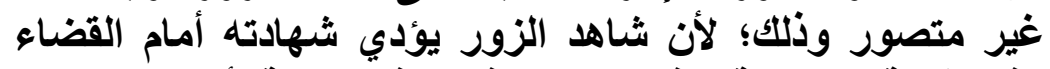

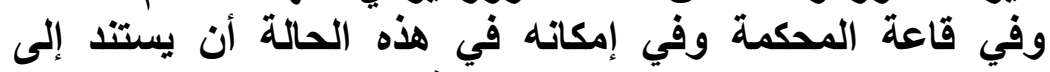

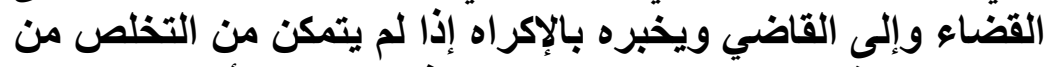

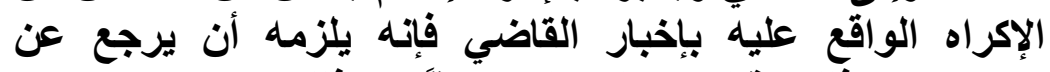

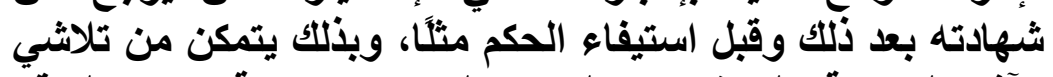
الآثار المترتبة على شهادته الزور والتي كانت نتيجة الإكراه الواقع

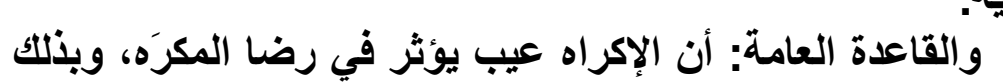

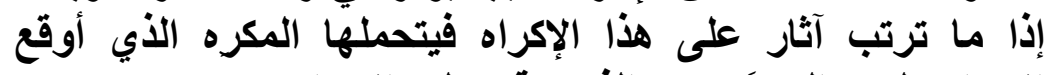
الإكراه وليس المكرَه وهو الذي وقع عليه الإكراه.

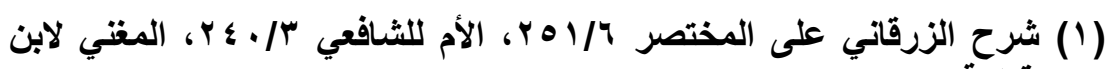

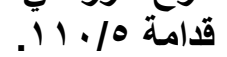

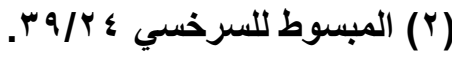




\section{خاتمة البمث}

النتائج التي توصلت إلبها من هذا البحث

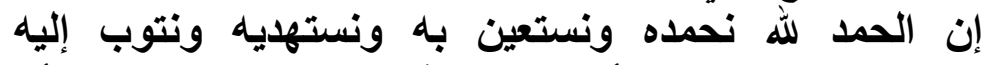

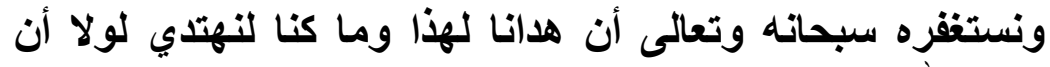
هدانا الله.

ونصلي ونسلم على سيد الخلق وإمام المرسلين وخاتم النبيين

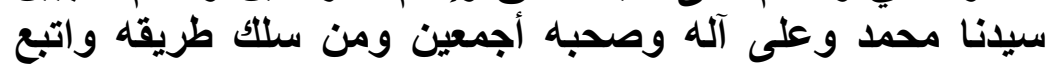
سنته إلى يوم الاين. - سمئ.

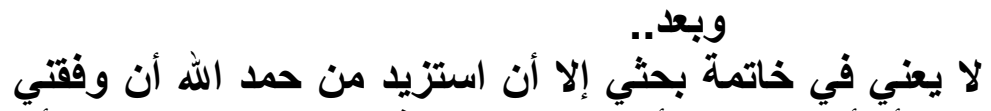

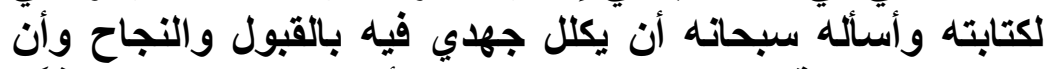

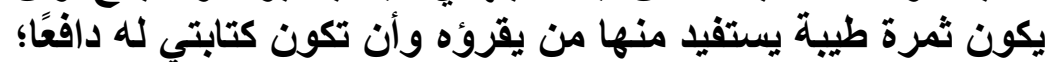

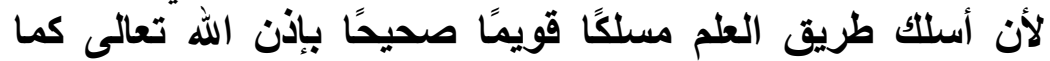

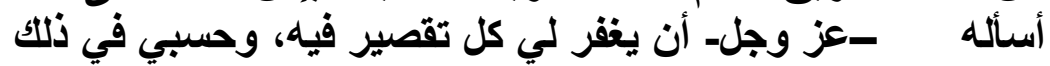

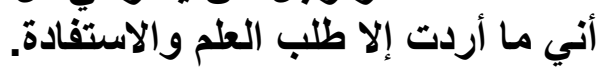

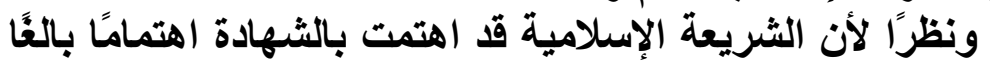

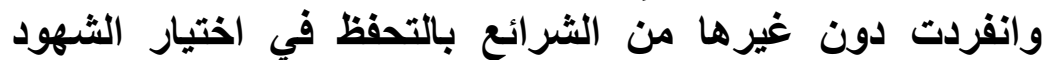

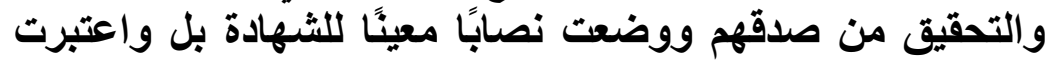
الشهادة الزور من أكبر الكبائر.

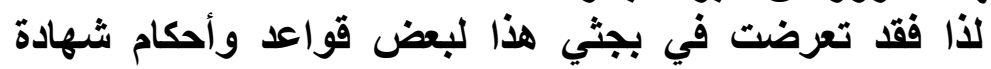
أما عن النتائج التي توصلت الإسي إليها فيمكن إجمالها على النحو الزور في الفقه الإسلامي. التالي:ا. تعرضت في باية الأمر إلى تعريف الشهادة في اللغة وعند

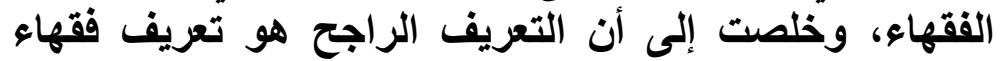

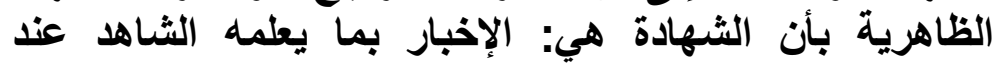

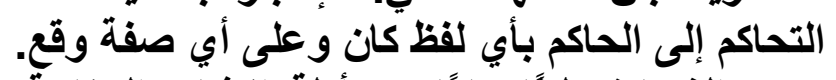

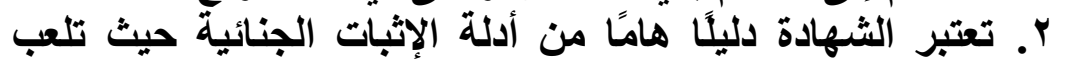

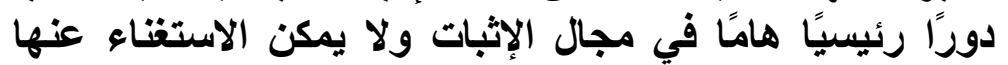

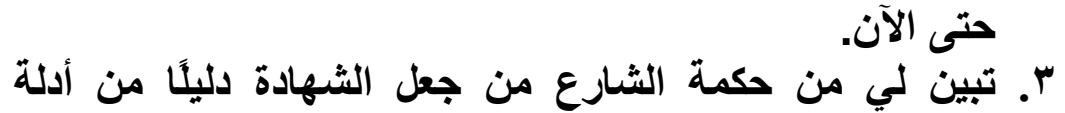

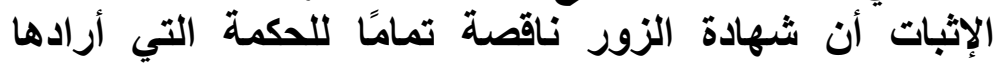
الشارع من الثهادة. 
؛. كما تبين لي من خلالل العرض للنظرة التاريخية لثهادة الزور

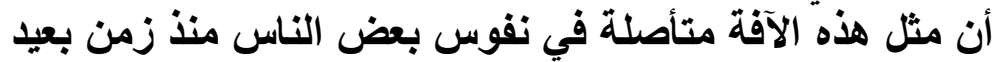
وقد وضعت كل شريعة على حدة العقوبة الزاجرة لمرتكبها

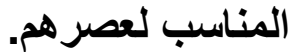
๑. هذر الإسلام من شهادة الزور وحرمها وعدها من الكبائر.

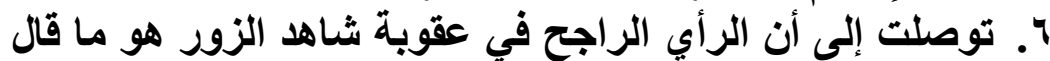

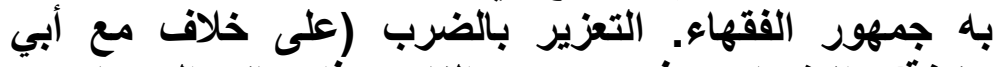

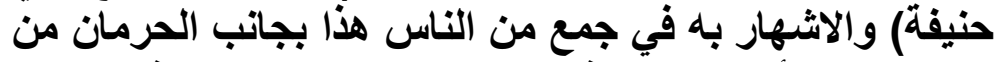

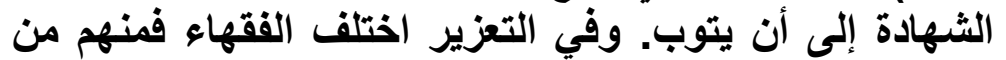

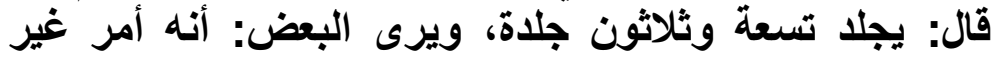

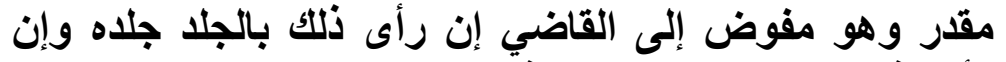

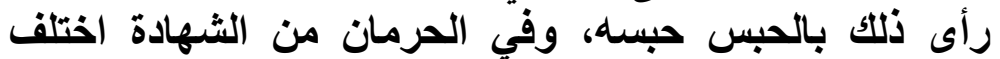

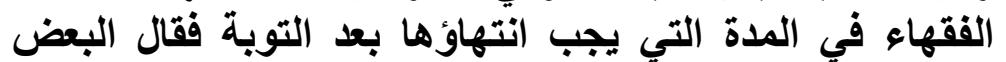

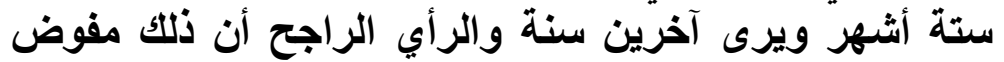

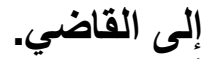
V. أن الرجوع عن شهادة الزور أمر مرغوب فيه حيث فيه خلاص

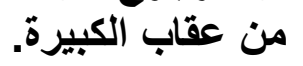
^. يجوز في أضيق الحدود استخلاص الحق بشهادة الزور إذا كان قائمًا بعينه وليس من سبيل للحصول عليه غير طريق شهادة الزئ 9. والزوب تعزير الثهود عند الرجوع عن شهادة الزور قبل الحكم وبطلان الثهادة وعدم الحكم بها اتفاقا.

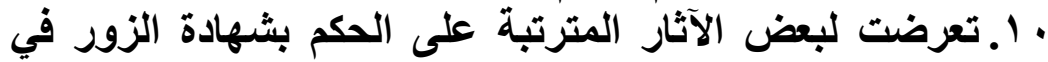

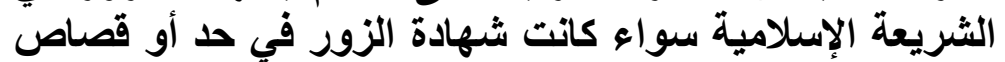

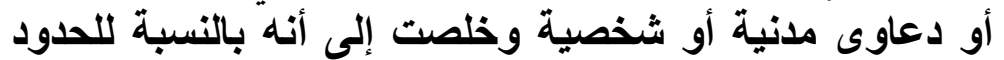

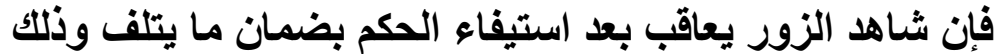

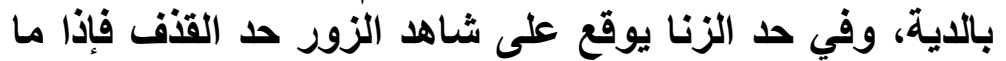

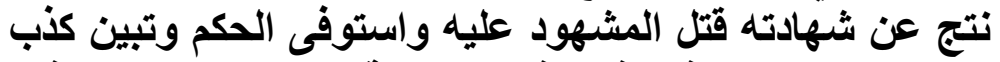

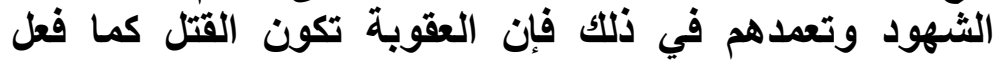

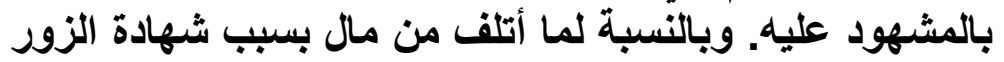

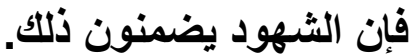
11.وتعرضت أيضًا للأثر المترتب على الإكراه في شهادة الزور وخلصت إلى أن شاهد الزور في إمكانه أن يتخلص من الإكراه 
الواقع عليه خاصة، وأن الثهادة تؤدي أمام القاضي وفي مجلس القضاء وهو بذلك يكون في إمكانه أن يفشي سر من النّامي أكر هل على الثهادة.

rا.خلصت أخيرًا إلى أن العقوبة التي يجب تطيقها على شاهـا

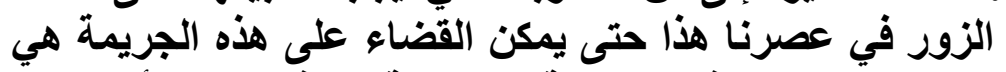

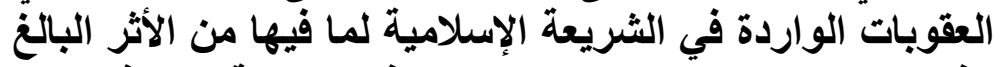

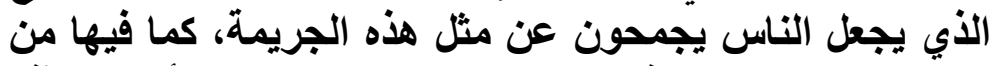

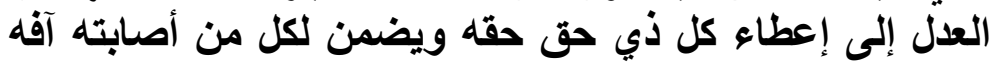

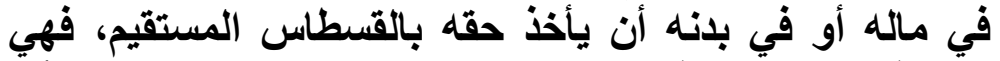

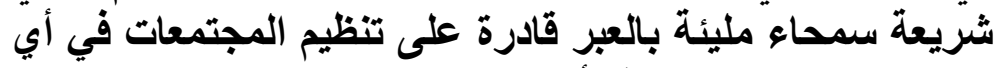
زمن كان لمرونتها وعظم أحكامها. 


\section{فهرس المصادر}

أولًَا: القرآن الكريم جل من أنزله.

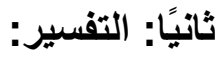

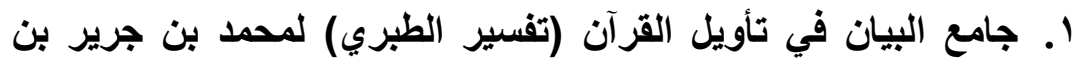

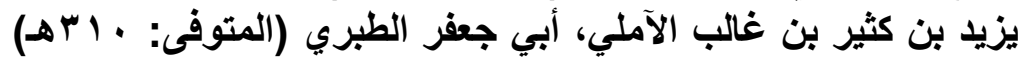

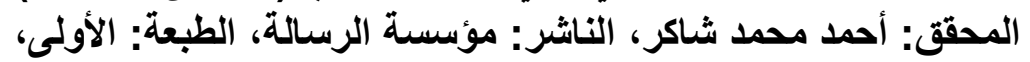

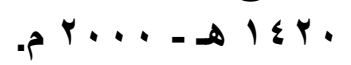

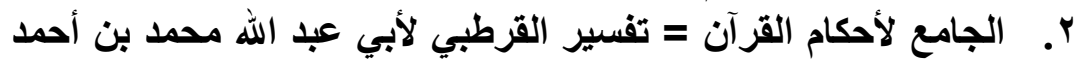

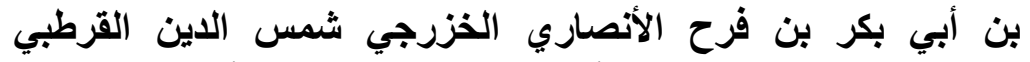

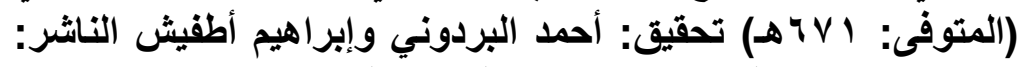

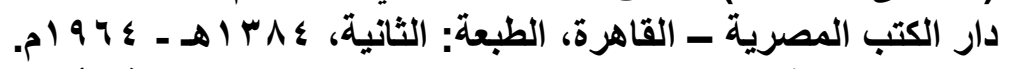

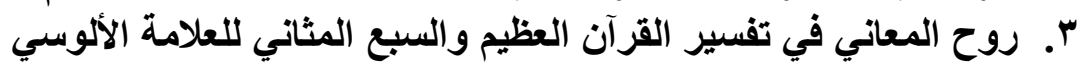

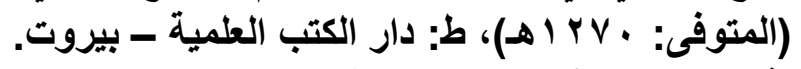

؛. في ظلال القرآن للشيخ سيد قطب إبر إبراهيم حسين الشاربي (المتوفى:

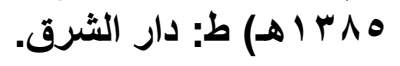

๑. الكشاف عن حقائق غوامض الثرف التززيل (تفسير الزمخشري) لأبي القاسم

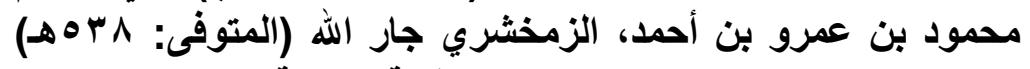

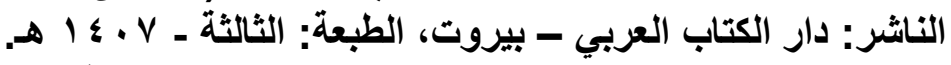

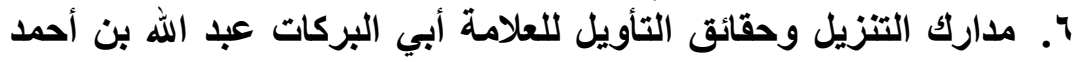

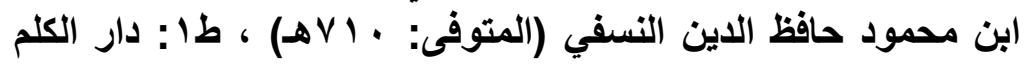

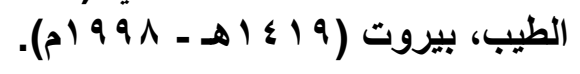

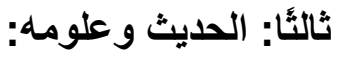

ا. الجامع المسند الصحيح المختصر من أمور رسول الله صلى الله عليه

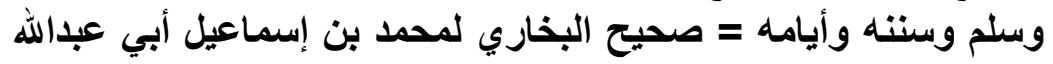

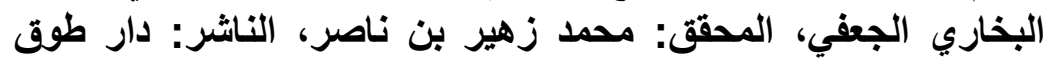

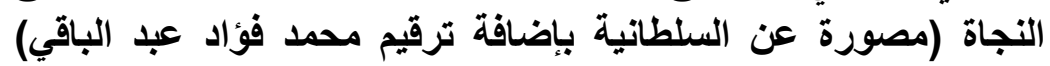

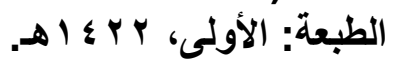

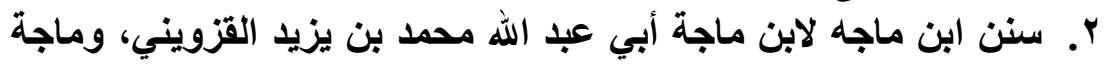

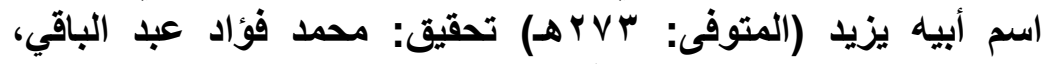
الناشر: دار إحياء الكتب العربية ـ فيصل عيسى البابي الحلبي. 


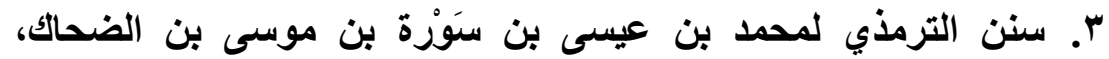

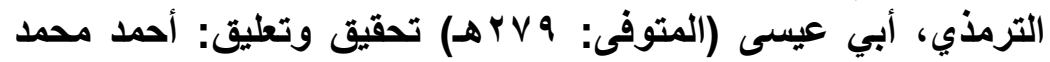

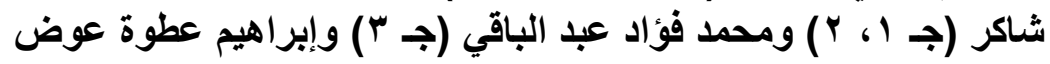

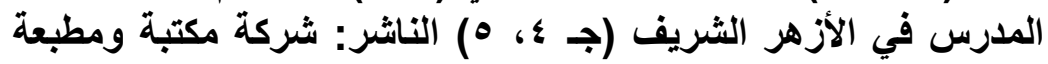

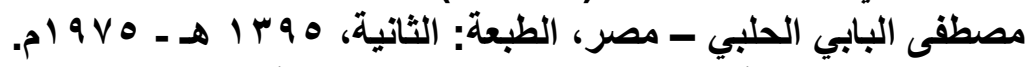

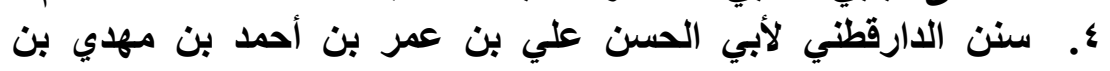

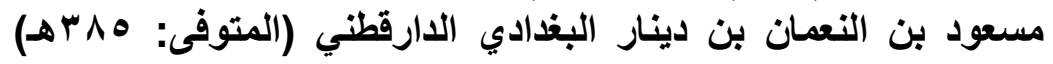

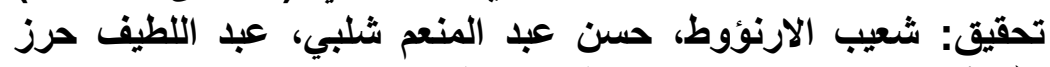

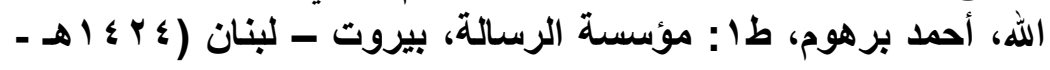

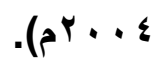

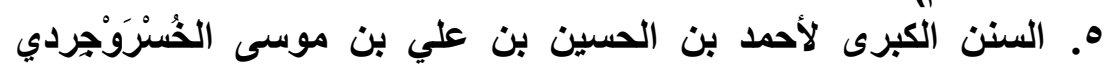

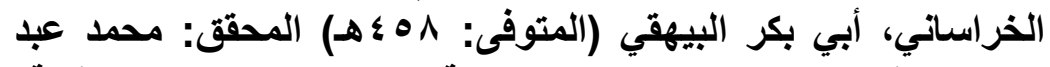

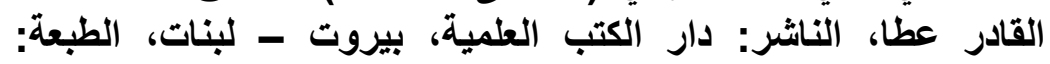

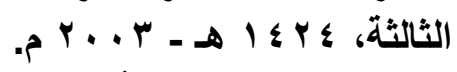

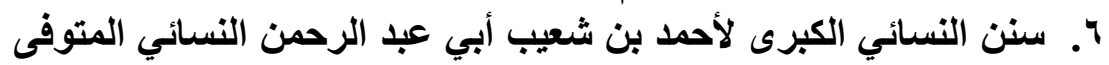

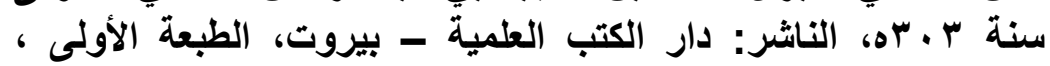

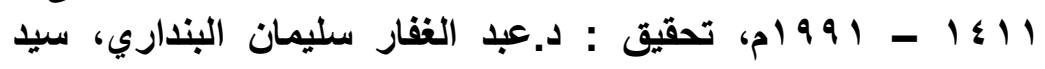
كسروي حسن.

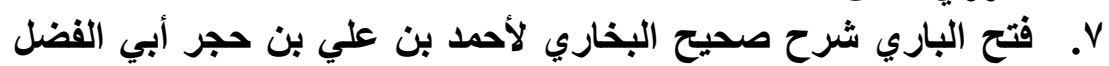

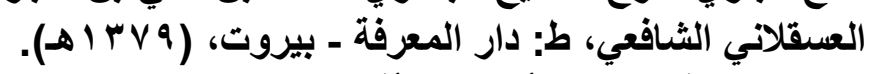

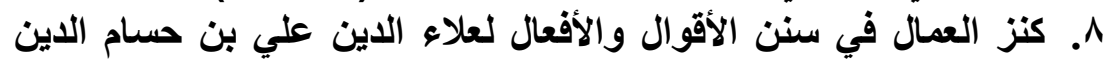

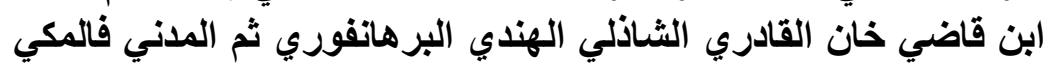

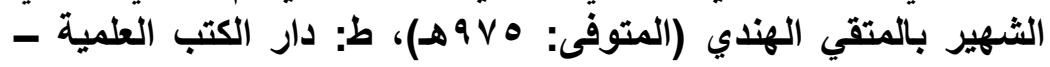
بيزوت.

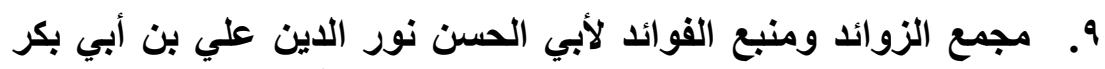

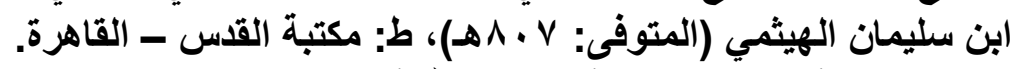

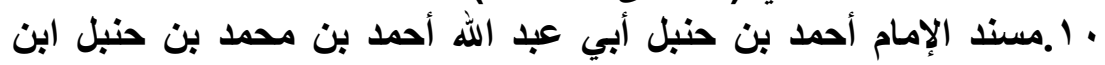

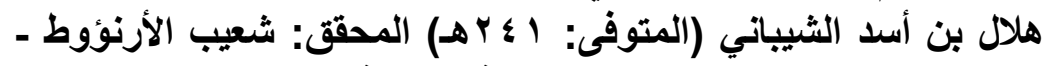

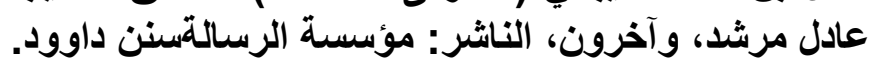
11

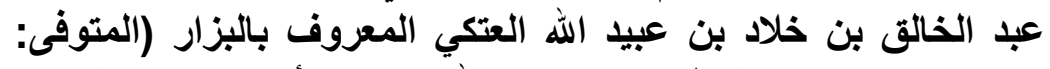

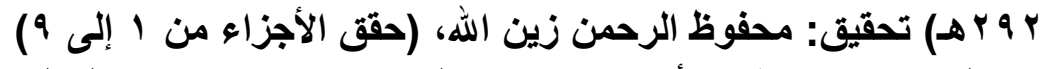

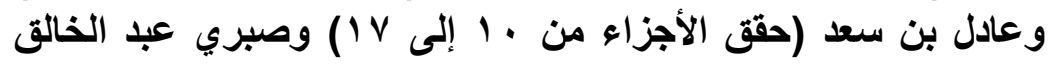


الثافعي (حقق الجزء ^1/) الناشر: مكتبة العلوم والحكم - المدينة

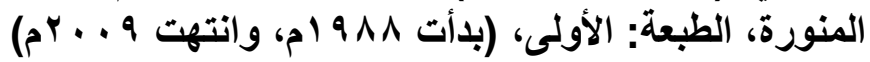

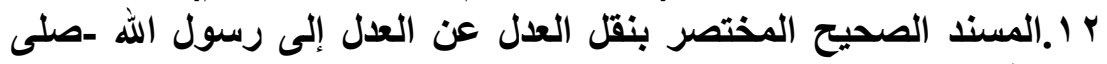

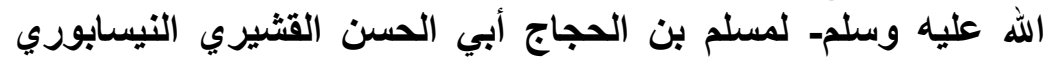

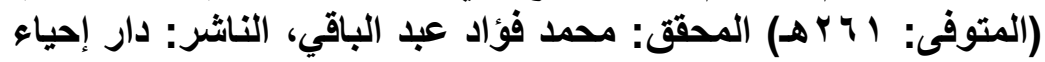

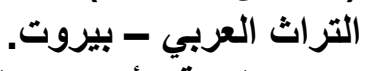
rا.نصب الراية لأحاديث الهداية مع حاثيته بغية الألمعي في تخريج

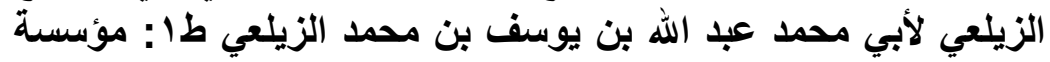

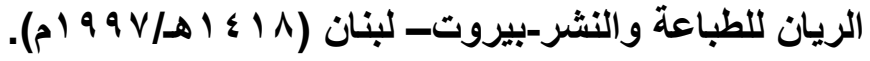

$$
\text { رابعًا: مراجع الفقه: }
$$

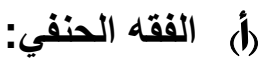

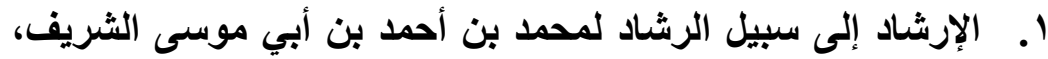

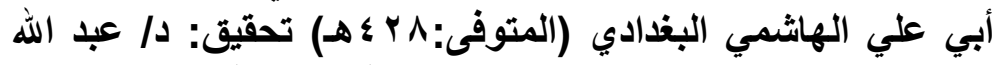

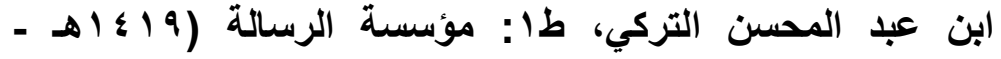
r. الأصنْ لأبي عبد الله محمد بن الحسن بن فرقد الثيباني (المتوفى:

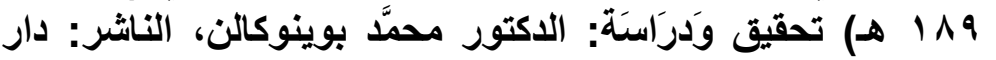

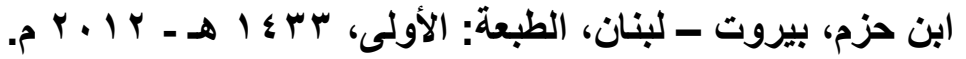

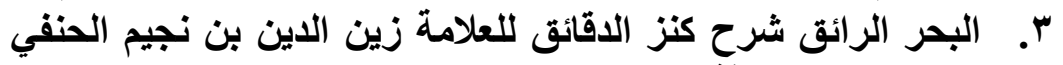

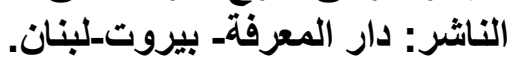

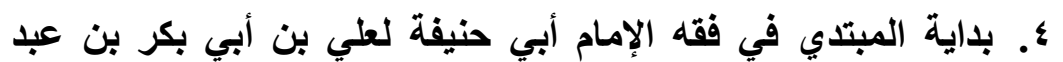

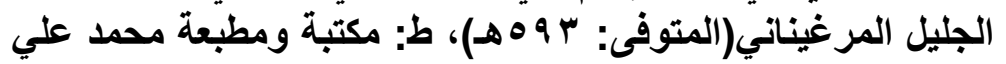

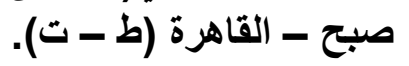

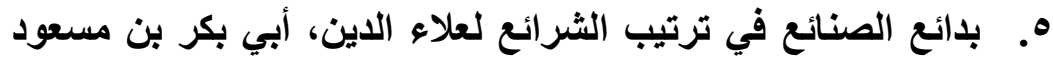

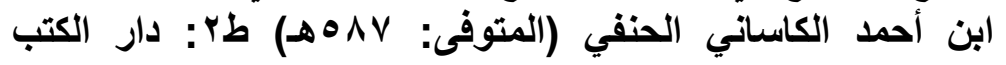

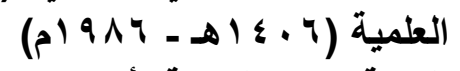

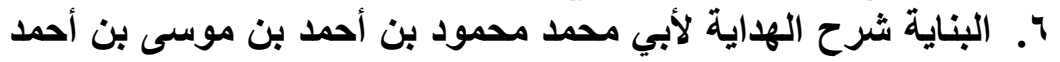

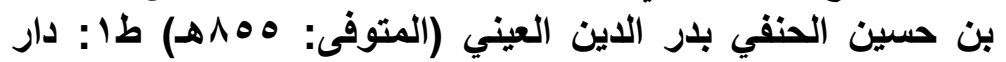

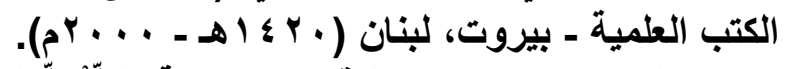

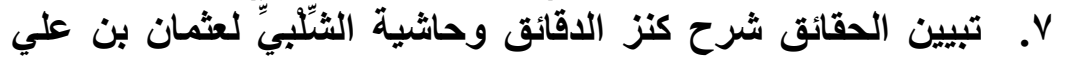

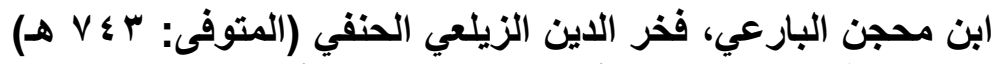
مع حاثية: شهاب الدين أحمد بن محمد بن الحمد بن النين يونس ابن الن 


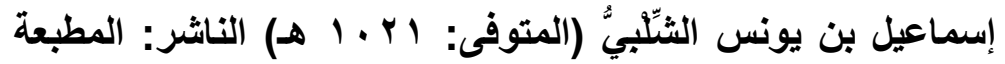

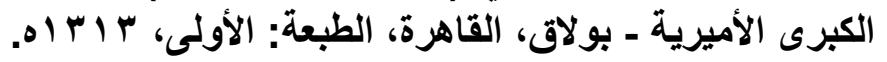

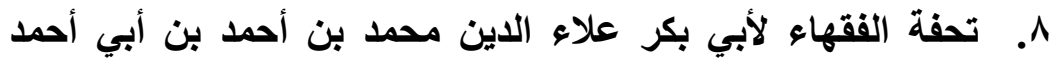

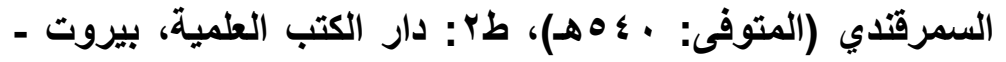

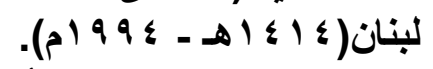

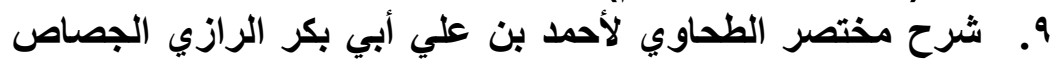

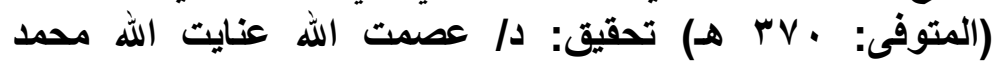

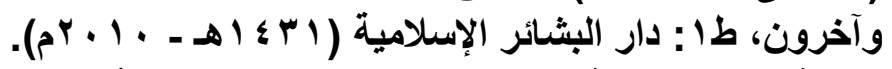

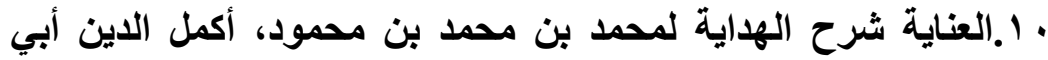

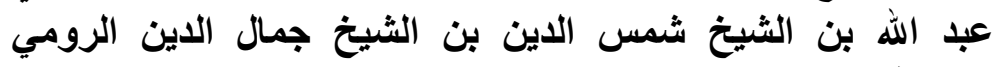

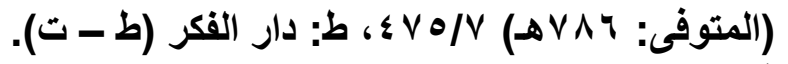

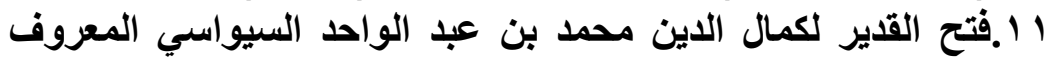

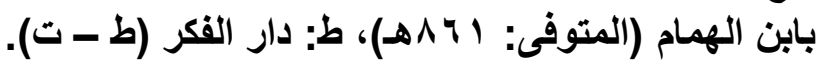

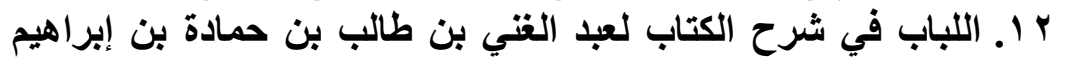

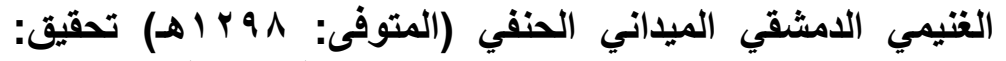

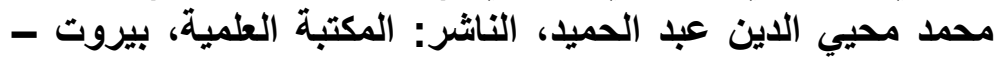

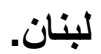

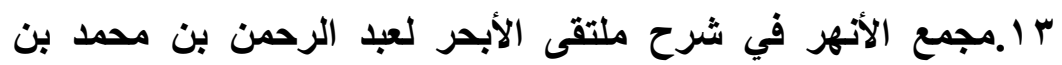

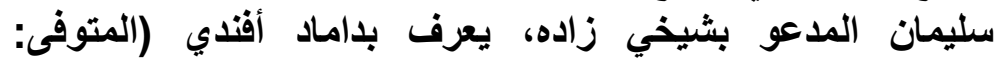

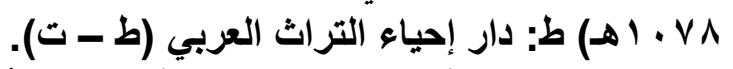

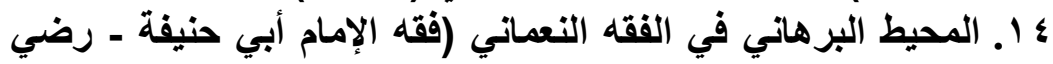

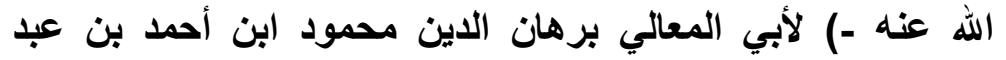

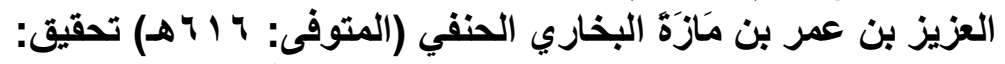

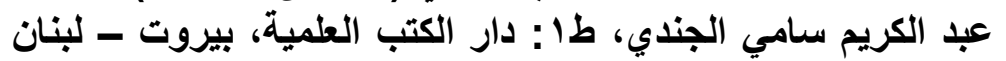
(إئ) 1.الهداية في شرح بلاية المبتدي لعلي بن أبي بكر بن عبد الجليل

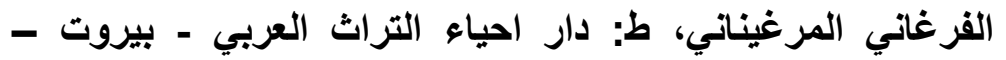

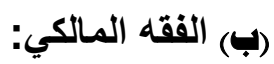

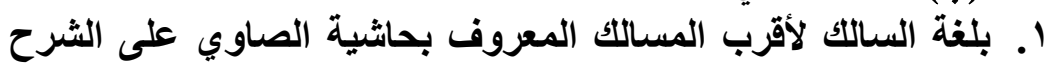

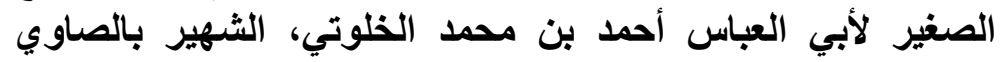

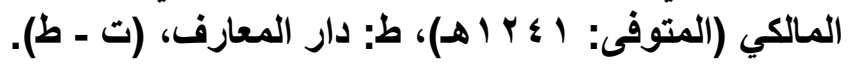


r. التفريع في فقه الإمام مالك بن أنس - رحمه الله - لأبي إسحاق عبيد

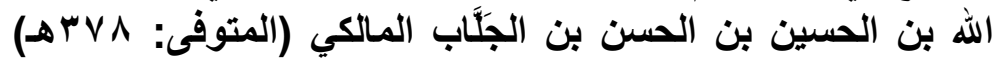

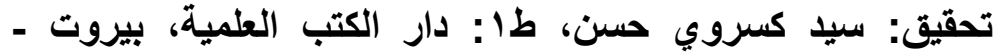

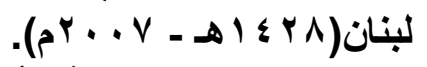

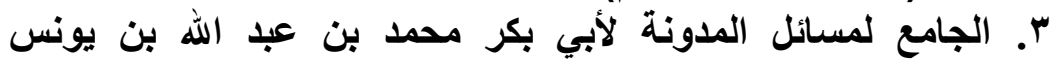

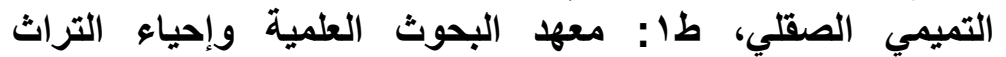

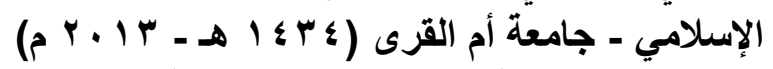

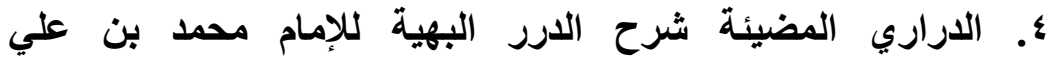

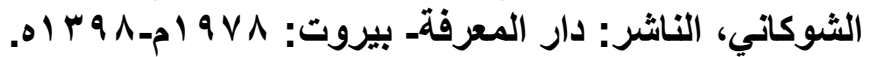

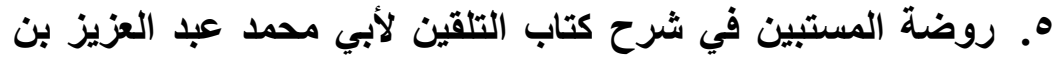

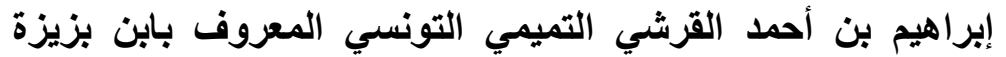

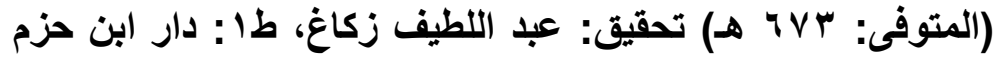

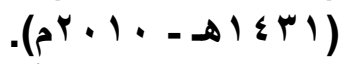

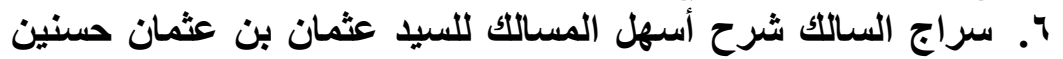

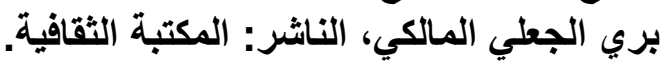

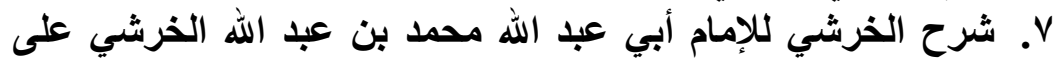

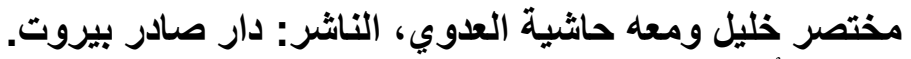

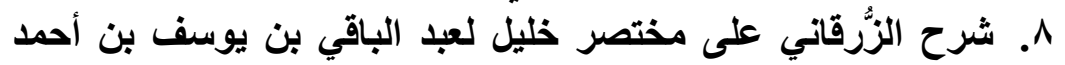

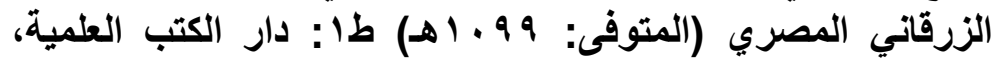

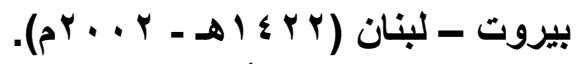

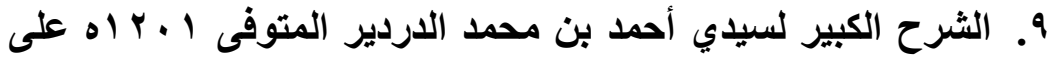

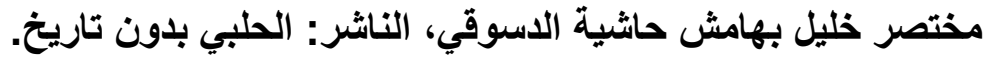

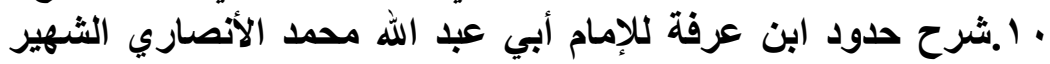

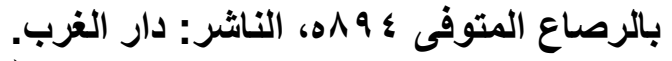

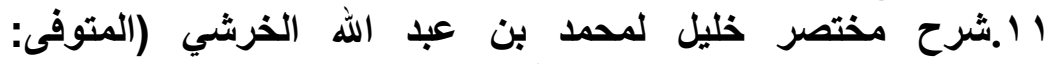

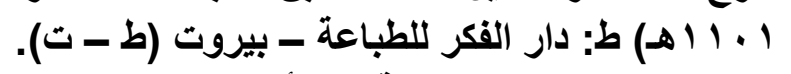

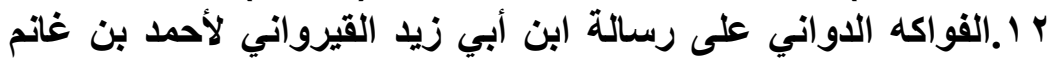

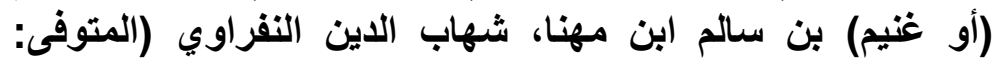

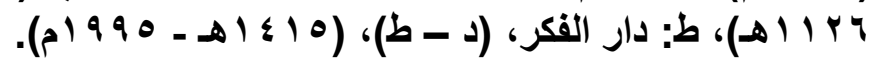

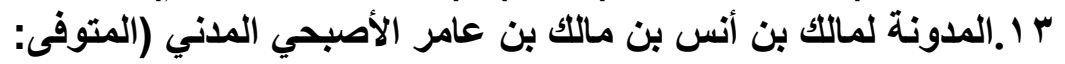

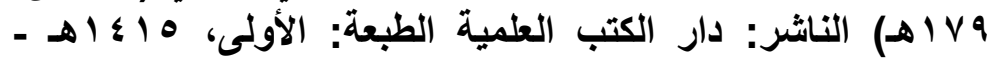
. 
ع ا.المعونة على مذهب عالم المدينة (الإمام مالك بن أنس) لأبي محمد

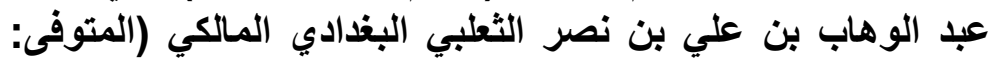

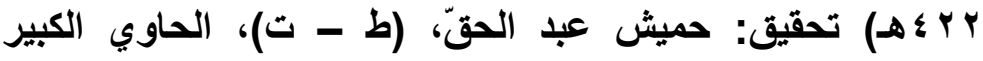

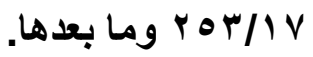

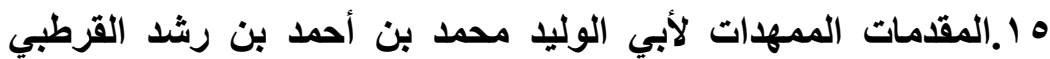

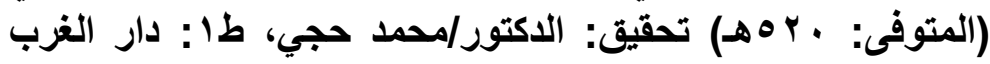

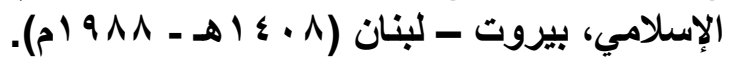

17 ا.مواهب الجليل في شرح مختصر خليل لشمس الدين أبي عبد الله

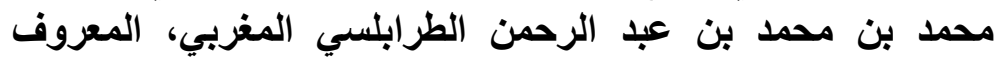

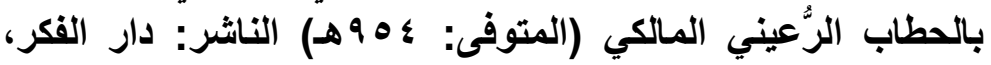

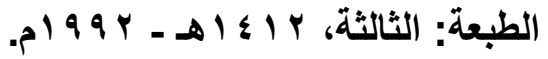

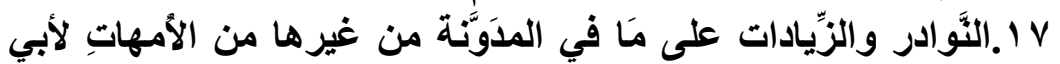

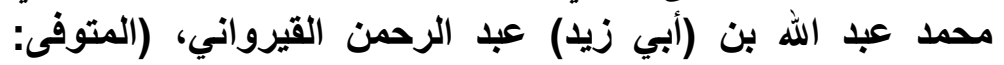

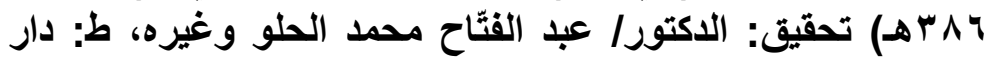

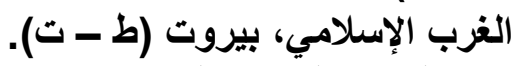

1 1.الهداية الكافية الثافية لبيان حقائق الإمام ابن عرفة الثافي الوافية. (شرح

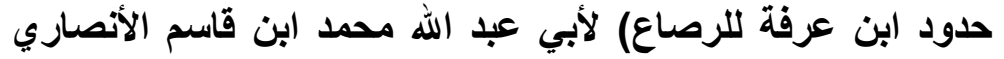

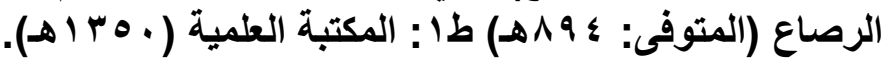

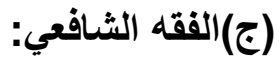
ا ـ إعانة الطالبين على حل ألفاظ فتح المعين (هو حاثية على فتح

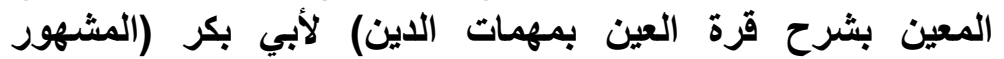

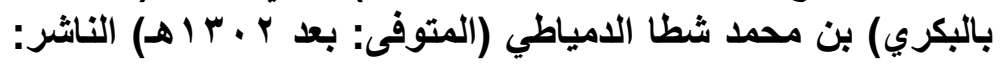

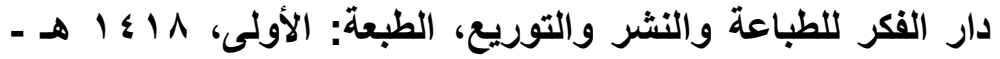
ا $199 \mathrm{~V}$ r. الإقناع في حل ألفاظ أبي شجاع لشمس الدين محمد بن أحمد الخطيب

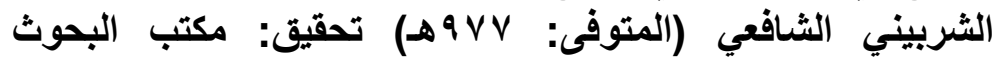

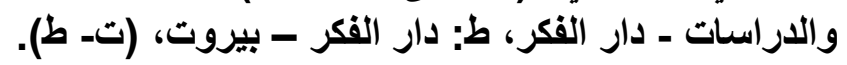
r. الأم لأبي عبد الله عبد الله محمد بن إدريس بن الفئ العباس الثافعي، ط:

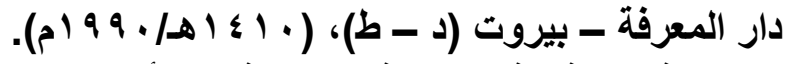

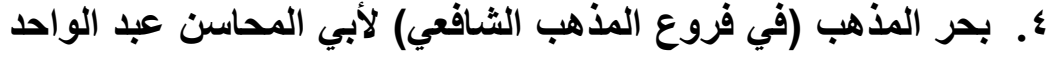

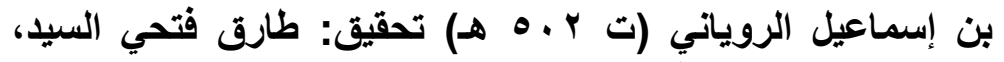

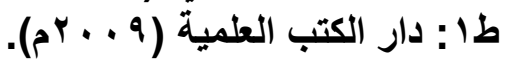


•. تحفة الحبيب على شرح الخطيب = حاشية البجيرمي على الخطيب،

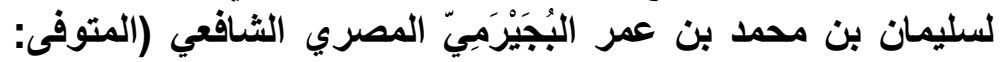

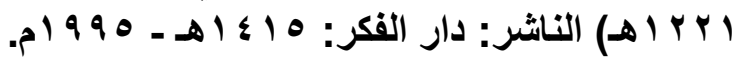

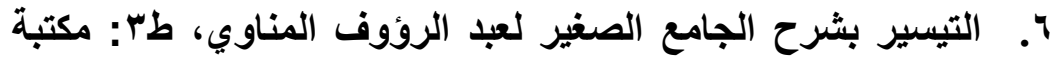

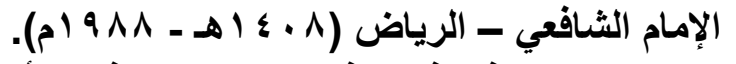

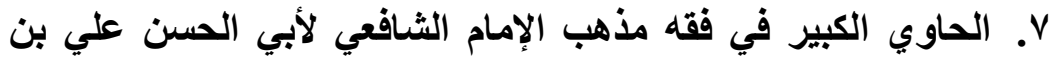

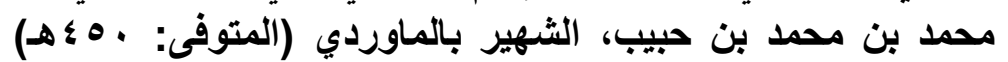

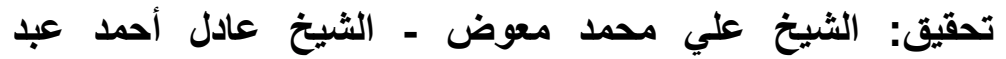

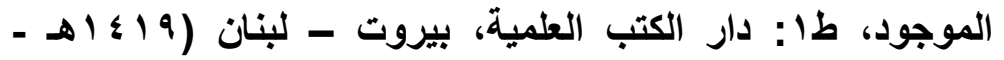

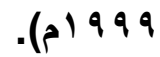

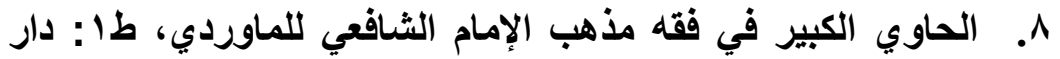

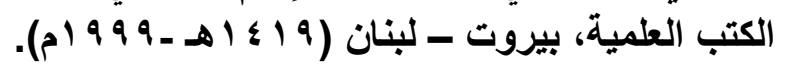

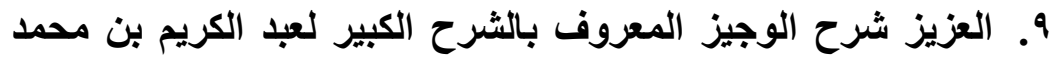

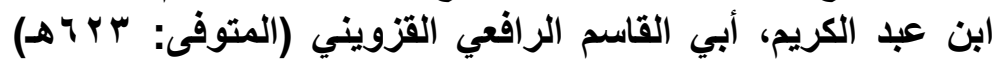

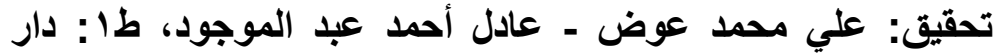

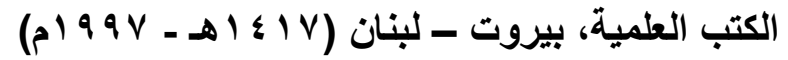

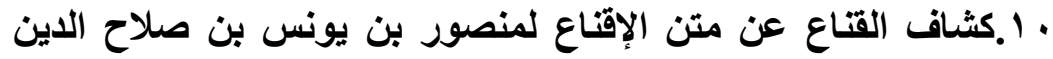

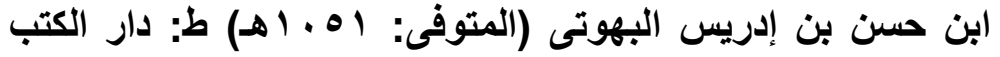

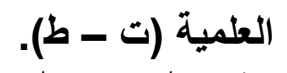

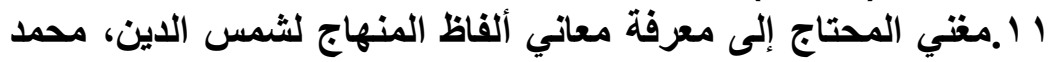

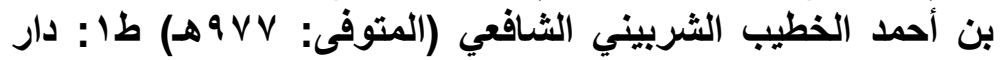

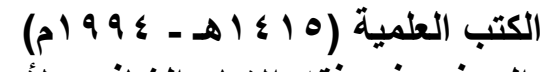

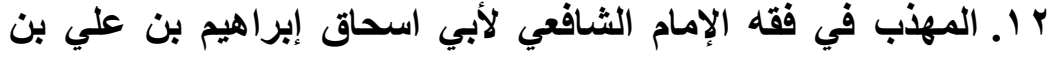

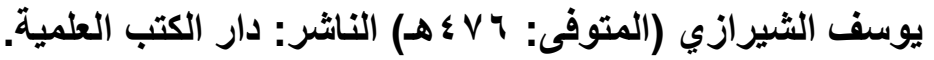

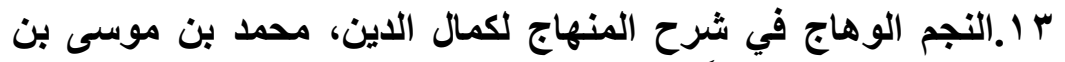

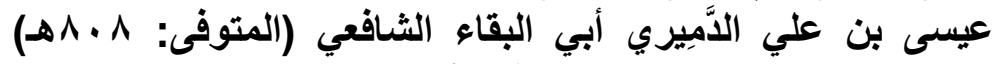

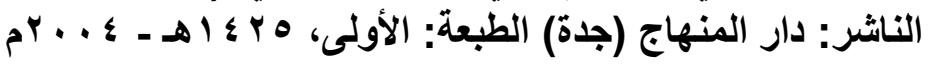

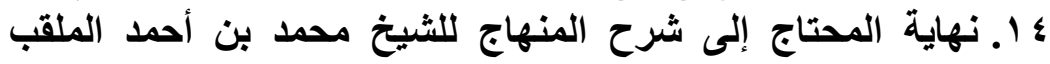

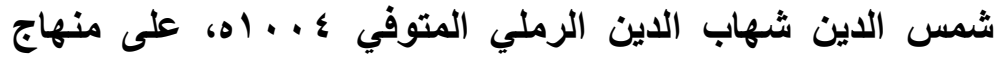

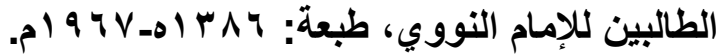

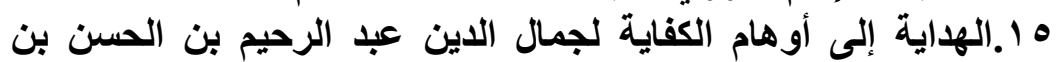

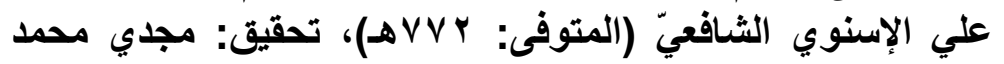


سرور باسلوم، ط: دار الكتب العلمية، (مطبوع بخاتمة "كفاية

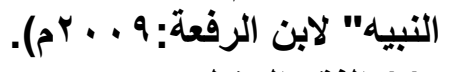

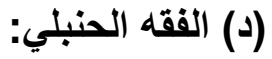

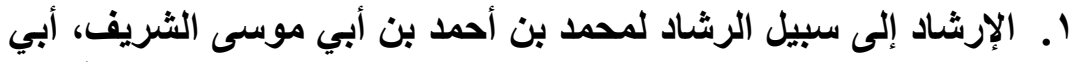

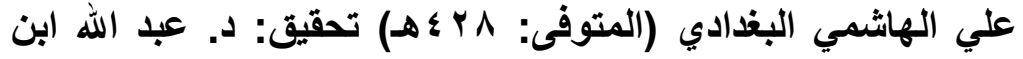

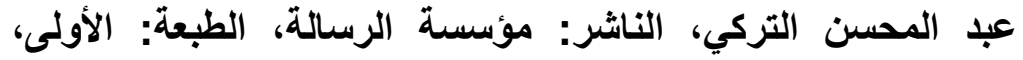

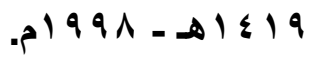

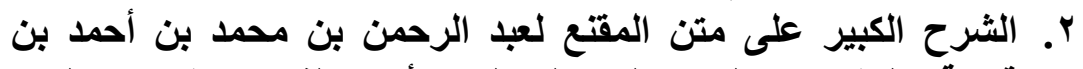

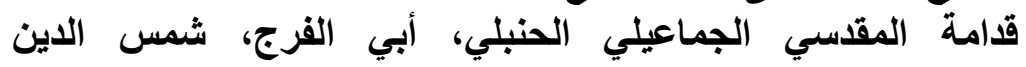

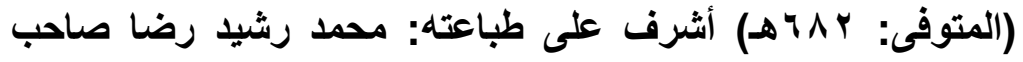

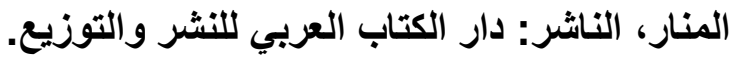

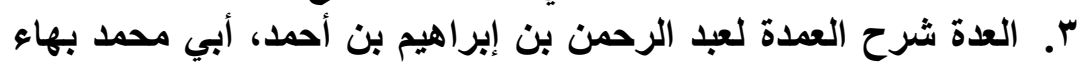

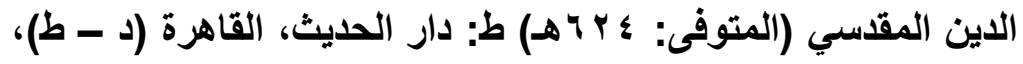

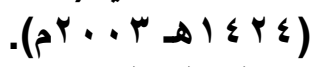

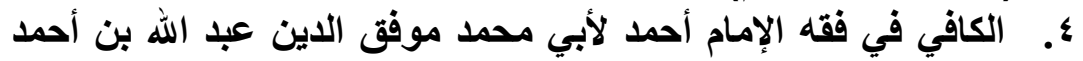

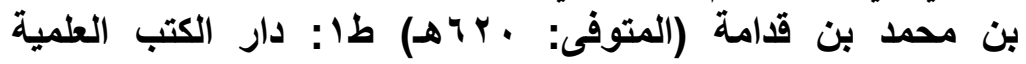

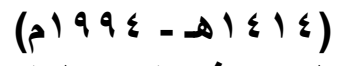

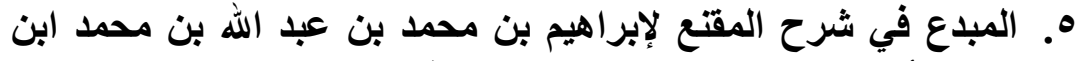

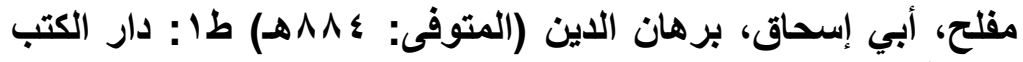

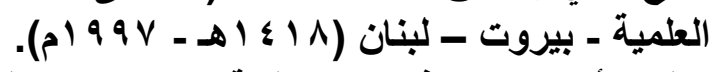

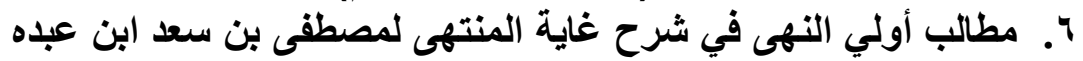

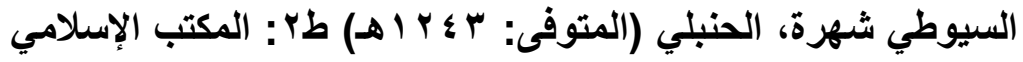

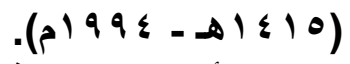

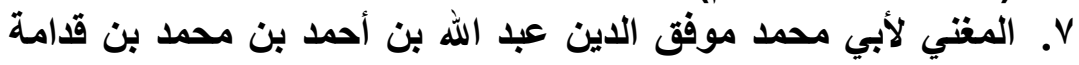

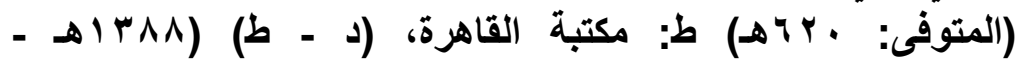

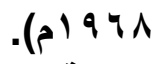
^. حاشية الجمل على شرح المنهاج للشيخ زكريا الأنصاري، الناشر: دار إحياء التراث العربي.

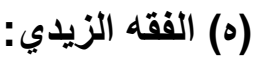
1. عيون الأزهار في الفقه الأئمة الأطهار للإمام أحمد بن يحيى المرتضى صده ؟ \&، الناشر: دار الكتاب اللبناني. 
1. جواهر الكلام شرح شرائع الإسلام للشيخ محمد حسن النجفي

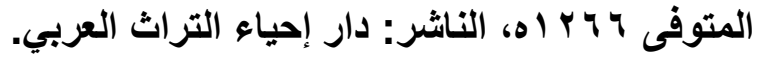

$$
\text { (ز) الفقه الإباضي: }
$$

ا. شفاء العليل للشيخ محمد بن يوسف أطفيش الناشر: مكتبة الإشاد.

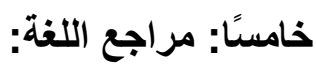

ا. تاج اللغة وصحاح العربية لأبي نصر إسماعيل بن حماد الجوهري

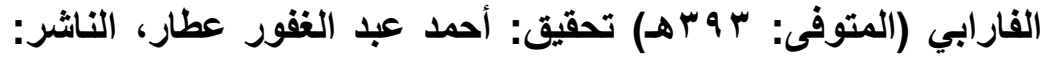

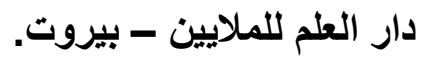

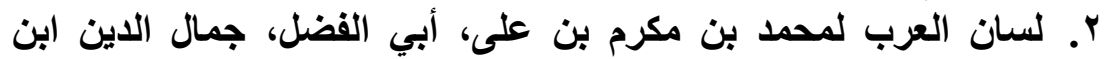
منظور الأنصاري الرويفعى الإفريقى (المتوفى:

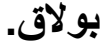

rا. مختار الصحاح لزين الدين أبي عبد الله محمد بن أبي بكر بن عبد القادر

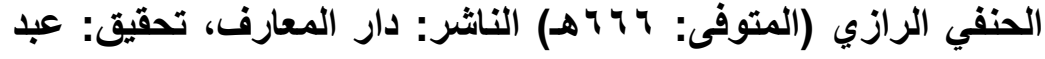
؛. معجم مقاييس اللغة لأحمد بن فارس بن زكرياء القزويني الرازي، أبي

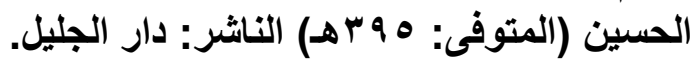

$$
\text { سادسًا: المراجع العامة: }
$$

r. الإجماع لأبي بكر محمد بن إبراهيم بن المنذر النيسابوري (المتوفى:

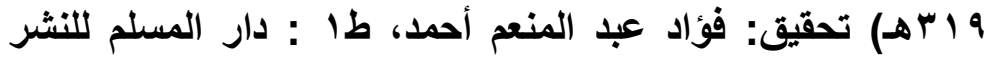

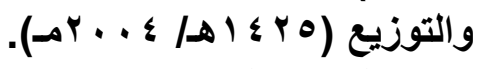

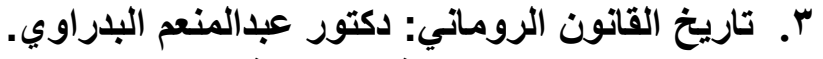

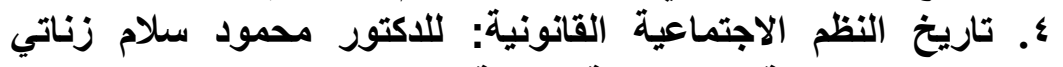

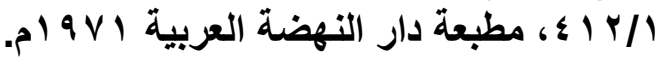

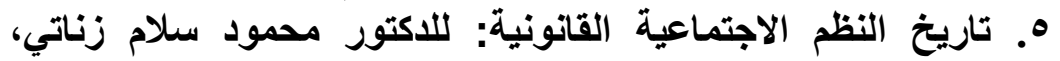

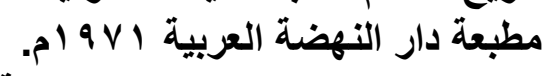

7. الثهادة الزور من الناحيتين القانونية والعلمية للاكتور/ بهاء هابيل

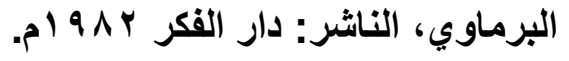


V. علم العقاب: للاكتور يسري أنور علي، والدكتورة آمال عثمان.

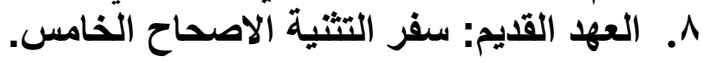

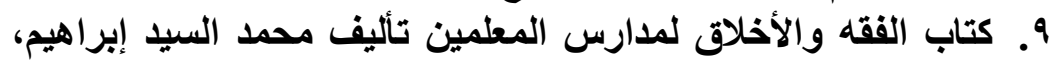

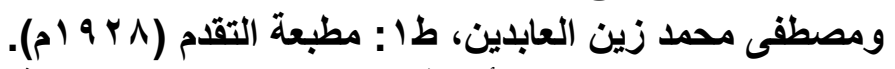

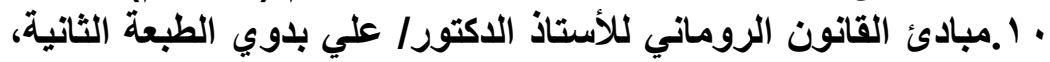
مطبعة إلياس فوزي بالقاهرة

11 ـ النظرية العامة للإثبات في التشريع الجنائي العربي المقارن: للأستاذ

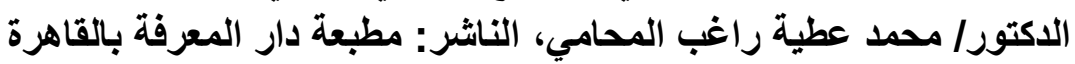
. 97. 